\title{
IMPLEMENTASI KOMUNIKASI EDUKATIF
}

DALAM PEMADUAN IMAN, ILMU DAN AMAL

\section{STUDI PEMBELAJARAN PAI DI SMA IT ABU BAKAR} YOGYAKARTA

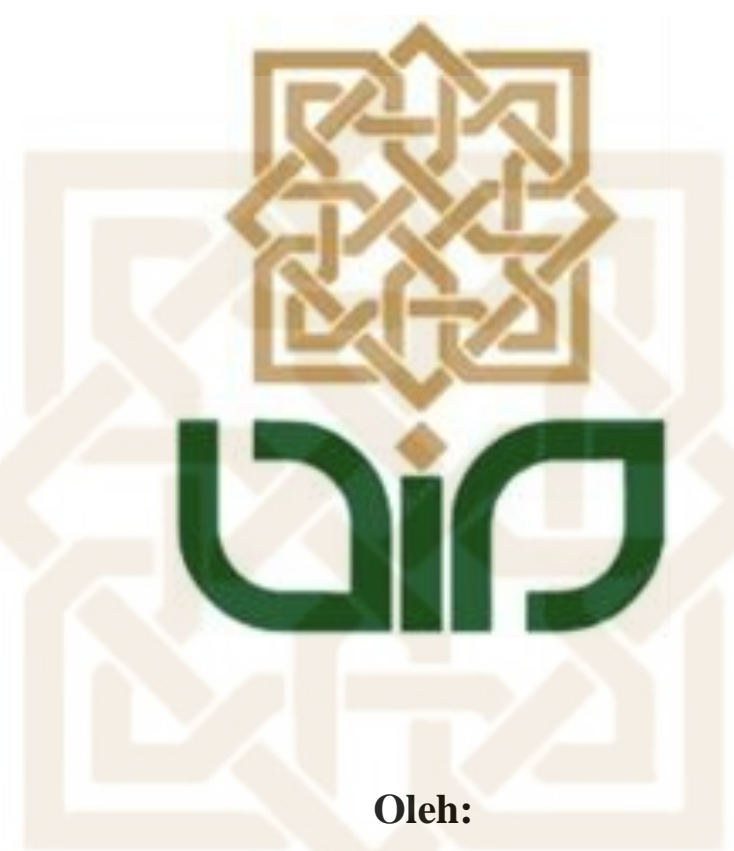

ANDRIANTO

NIM: 17204010045

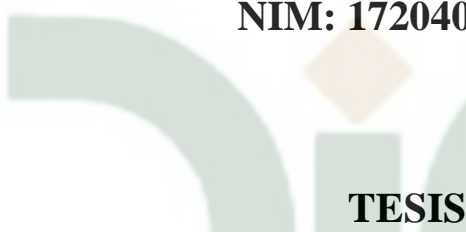

Diajukan kepada Program Magister (S2)

Fakultas Ilmu Tarbiyah dan Keguruan UIN Sunan Kalijaga

Untuk Memenuhi Salah Satu Syarat Guna Memperoleh Gelar Magister Pendidikan (M.Pd.)

Program Studi Pendidikan Islam

Konsentrasi Pendidikan Agama Islam

YOGYAKARTA

2019 


\section{PERNYATAAN KEASLIAN TULISAN}

Yang bertanda tangan di bawah ini:

$\begin{array}{ll}\text { Nama } & \text { : ANDRIANTO, S.Pd. } \\ \text { NIM } & : 17204010045 \\ \text { Jenjang } & : \text { Magister } \\ \text { Program Studi : Pendidikan Agama Islam } \\ \text { Konsentrasi }\end{array}$

menyatakan bahwa naskah tesis ini secara keseluruhan adalah hasil penelitian/karya saya sendiri, kecuali pada bagian-bagian yang dirujuk sumbernya.

Yogyakarta,15Oktober 2018

Saya yang menyatakan,

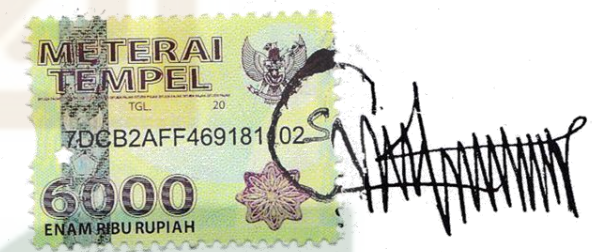

ANDRIANTO,S.Pd.

NIM : 17204010045 


\section{PERNYATAAN BEBAS PLAGIASI}

Yang bertanda tangan di bawah ini:

$\begin{array}{ll}\text { Nama } & : \text { ANDRIANTO, S.Pd } \\ \text { NIM } & : 1720404010045 \\ \text { Jenjang } & : \text { Magister } \\ \text { Program Studi } & : \text { Pendidikan Agama Islam } \\ \text { Konsentrasi } & : \text { Pendidikan Agama Islam }\end{array}$

menyatakan bahwa naskah tesis ini secara keseluruhan benar-benar bebas dari plagiasi. Jika dikemudian hari terbukti melakukan plagiasi, maka saya siap ditindak sesuai ketentuan hukum yang berlaku.

Yogyakarta $\ 5$ Oktober 2018

Saya yang menyatakan,

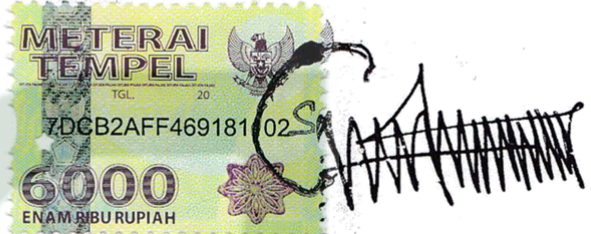

ANDRIANTO,S.Pd.

NIM : 17204010045 


\section{KEMENTERIAN AGAMA REPUBLIK INDONESIA UNIVERSITAS ISLAM NEGERI SUNAN KALIJAGA \\ FAKULTAS ILMU TARBIYAH DAN KEGURUAN}

Alamat : JI. Marsda Adisucipto, Teip (0274) 589621. 512474 Fax, (0274) 586117 tarbiyah.uin-suka.ac.id Yogyakarta 55281

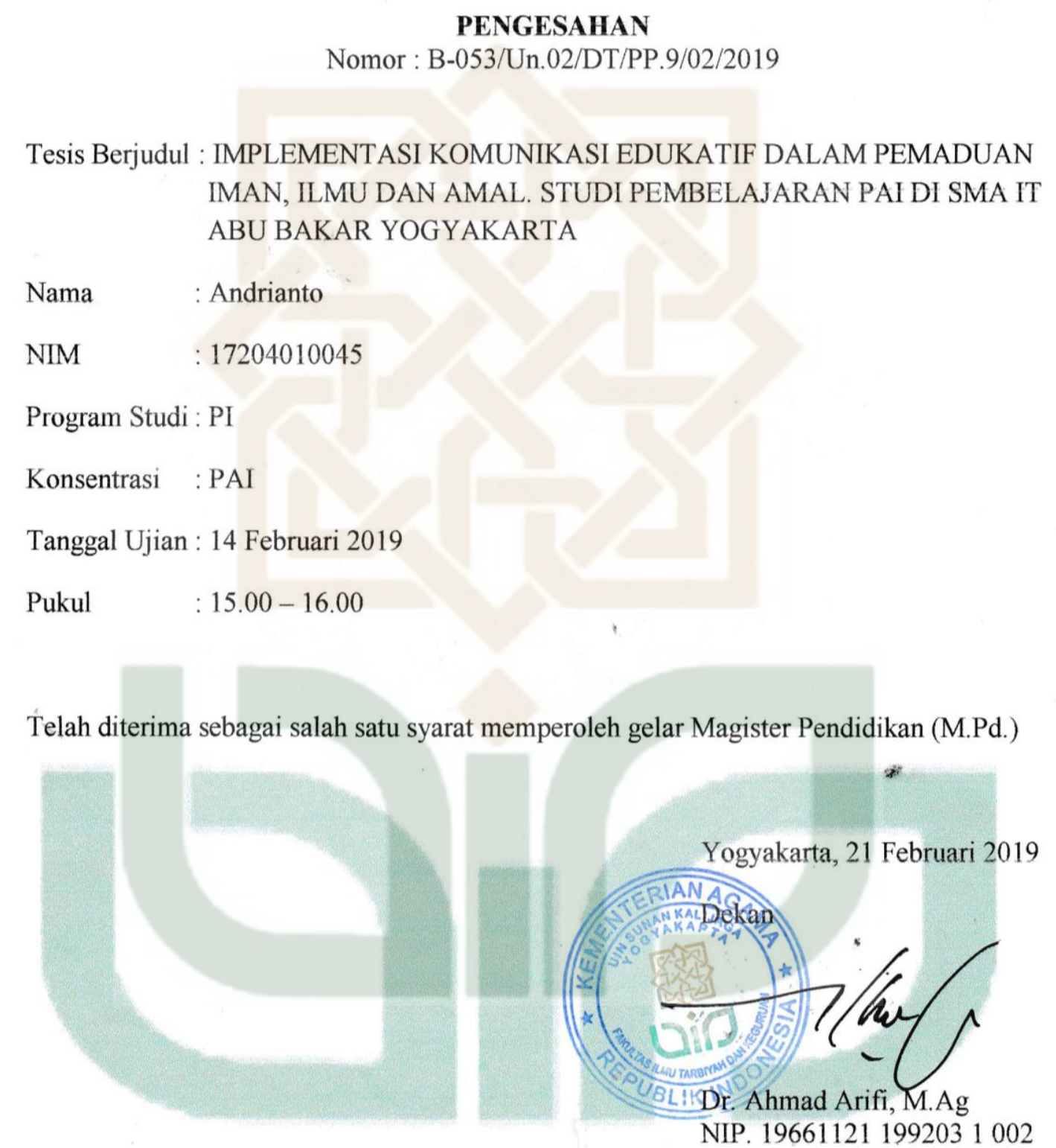




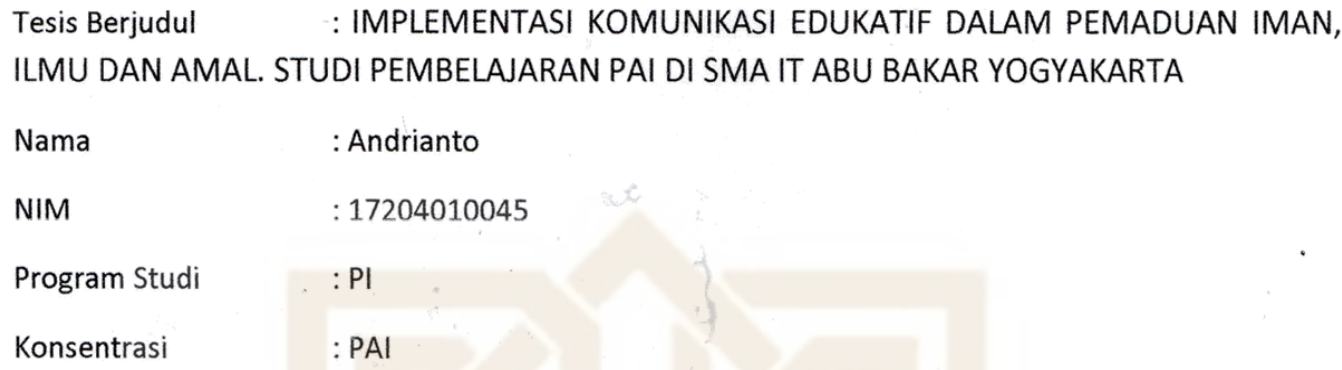

Telah disetujui tim penguji untuk munaqosyah

Ketua/Pembimbing $\quad$ : Dr. Usman, SS., M. Ag.

Sekretaris/Penguji i : D̂r. iviuqowim, îi.Âg.

Penguji II

: Dr. Istiningsih, M. Pd.

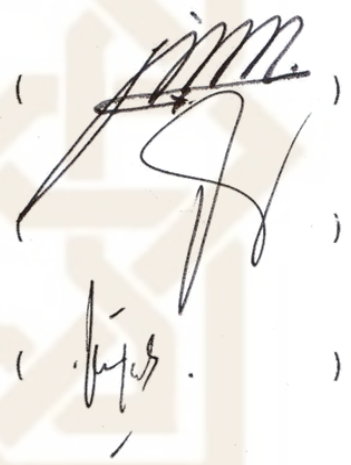

Diuji di Yogyakarta pada :

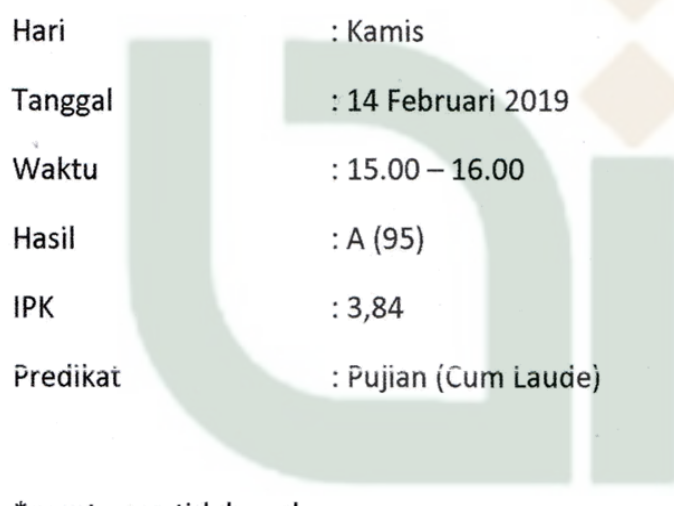

*coret yang tidak perlu 
NOTA DINAS PEMBIMBING

\author{
Kepada Yth., \\ Dekan FITK \\ UIN Sunan Kalijaga \\ Yogyakarta
}

Assalami'alaikum wr. wb.

Setelah melakukan bimbingan, arahan, dan koreksi terhadap penulisan tesis yang berjudul:

IMPLEMENTASI KOMUNIKASI EDUKATIF DALAM PEMADUAN

IMAN, ILMU DAN AMAL. STUDI PEMBELAJARAN PAI DI SMA IT

ABU BAKAR YOGYAKARTA

Yang ditulis oleh:

Nama

: ANDRIANTO, S.Pd.

NIM

: 17204010045

Jenjang

: Magister (S2)

Program Studi

: Pendidikan Islam

Konsentrasi

: Pendidikan Agama Islam

Saya berpendapat bahwa tesis tersebut sudah dapat diajukan kepada Program Magister (S2) Fakultas Ilmu Tarbiyah dan Keguruan UIN Sunan Kalijaga untuk diujikan dalam rangka memperoleh gelar Magister Pendidikan (M.Pd).

Wassalamu'alaikum wr. wb.

Yogyakarta,29 Oktober 2018

Pembimbing,

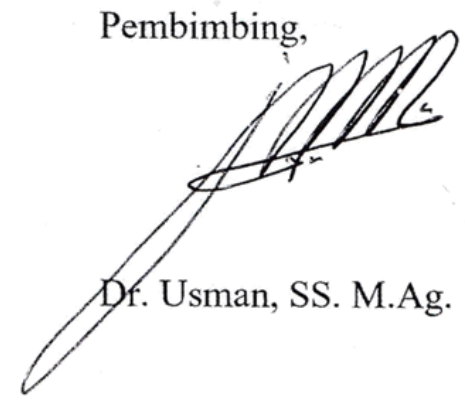




\section{PERSEMBAHAN}

Tiada kata lain yang terucap kepada-Mu ya Rabbi, selain kata syukur dan terimakasih atas rahmat-Nya, karunia dan kesempatan yang telah engkau berikan kepadaku untuk mempersembahkan sesuatu kepada orang-orang yang sangat kucintai.

Tesis Ini Penulis Persembahkan Kepada:

Almamater tercinta UIN Sunan Kalijaga Yogyakarta yang telah mendidikku menjadi seseorang yang mampu berfikir untuk lebih maju.

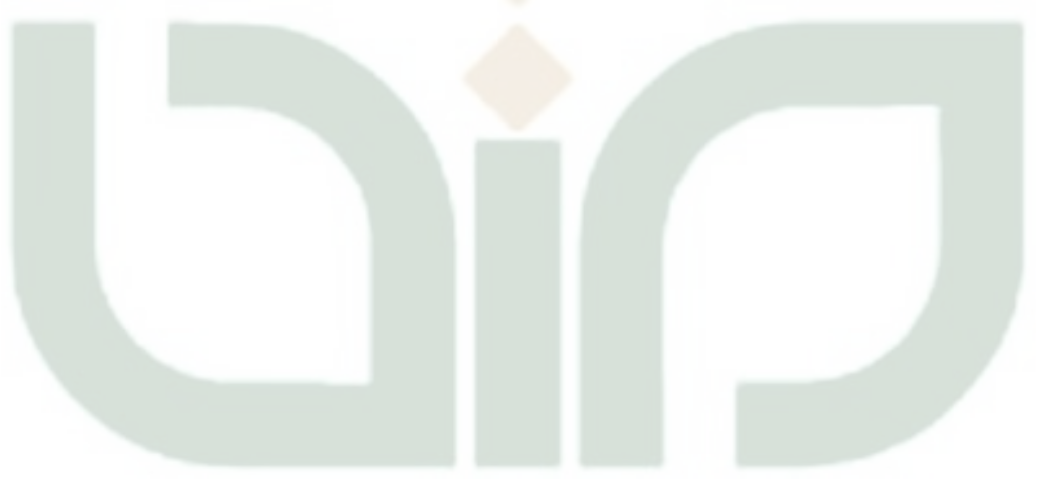




\section{MOTTO}

Selesai sebelum mulai, kata-kata yang bermakna dari tugas yang susah menjadi mudah, jika kita kerjakan dengan ikhlas semuanya akan menjadi mudah.

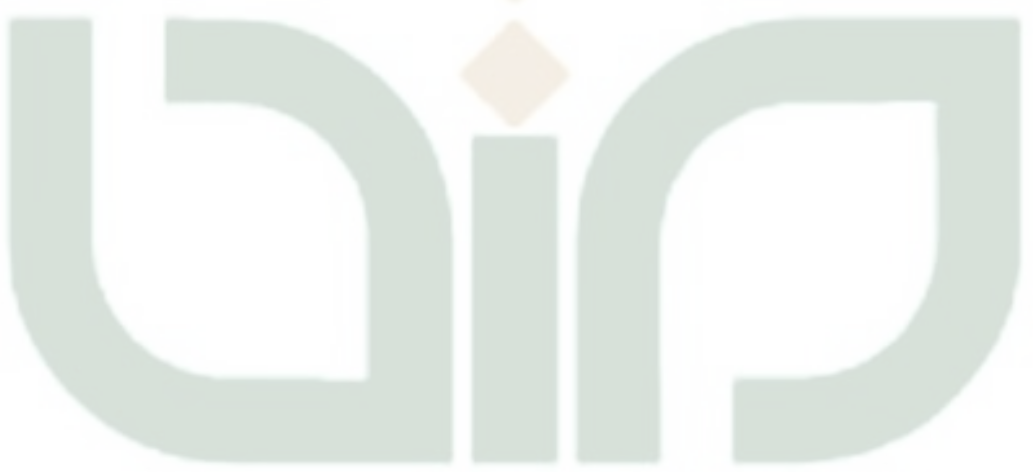

viii 


\begin{abstract}
ABSTRAK
Andrianto, S.Pd, Nim, 17204010045, Implementasi Komunikasi Edukatif Dalam Pemaduan Iman, Ilmu Dan Amal. Studi Pembelajaran PAI Di SMA IT Abu Bakar Yogyakarta. Tesis Program Studi Pendidikan Islam (PI) Program Magister (S2) Fakultas Ilmu Tarbiyah dan Keguruan UIN Sunan Kalijaga Yogyakarta.
\end{abstract}

Komunikasi edukatif dalam pemaduan iman, ilmu dan amal adalah komunikasi yang dilakukan oleh dua orang atau lebih yang mana kominukasi tersebut bersifat mendidik. Komunikasi ini sangant baik untuk dikuasai oleh guru demi kelancaran peserta didik.

Jenis penelitian yang digunakan penulis yakni jenis penelitian kualitatif. subyek penelitian ini yaitu guru PAI dan siswa SMA IT Abu Bakar Yogyakarta. Pengumpulan data dilakukan dengan mengadakan observasi, wawancara, dokumentasi dan triangulasi. Analisis data dilakukan melalui empat tahap yaitu: klarifikasi data, reduksi data, interprestasi data dan penarikan kesimpulan. Teknik pengumpulan data dengan metode induktif yaitu mencari data sebanyakbanyaknya lalu disimpulkan (umum-khusus).

Adapun hasil penelitian ini yaitu: 1) konsep karakteristik dan Implementasi komunikasi edukatif dalam pemaduan iman, ilmu dan amal. Studi pembelajaran PAI di SMA IT Abu Bakar Yogyakarta, jadi seorang guru harus menyiapkan bahan ajar dan seorang guru harus mampu menjelaskan dan bisa menguasai materi yang di ajarkan di dalam kelas, dan seorang guru harus mampu memberikan contoh dalam kehidupan sehari-hari supanya siswa mudah memahami isi materi yang di ajarkannya dan konsep dalam pembelajaran PAI mengacu pada kurikulum JSIT dan penggabungan dinas contohnya dengan memadukan iman, ilmu dan amal dalam kehidupan sehari-hari. 2) implementasi komunikasi edukatif dalam pemaduan iman, ilmu dan amal. Studi pembelajaran PAI di SMA IT Abu Bakar Yogyakarta, implementasinya pukul 7:30 semua siswa sudah di dalam kelas dan membaca do'a dan tadarus al-Qur'an, setiap hari jumat bagi yang putra wajib shalat jum'at, puasa senin kamis, makan bersama, mengadakan peringatan hari besar seperti pesantren kilat di bulan romadhon, bakti amal sosial dan di SMA IT Abu Bakar Yogyakarta tidak mengenal hari setiap hari ada program Islami, seni keislaman kaligrafi, tilawah, hadroh, nasid, dan ada mentoring agama dan ada Boarding Scool, Full Day, Ekstrakulikuler, olahraga, robotik, jurnal, pramuka (kepanduan), mentoring membeking iman, ilmu dan amal. 3) kontribusi lembaga pendidik dalam implementasi komunikasi edukatif dalam pemaduan iman, ilmu dan amal. Studi pembelajaran PAI di SMA IT Abu Bakar Yogyakarta, kontribusi konsepya jelas KYM yaitu konsursium yayasan mulia mengawal dan mengelola yayasan dari konsep pembelajaran, Islam jadi ruh utama di SMA IT Abu Bakar Yogyakarta jadi semua guru seperti guru PAI dan dari SD, SMP, SMA, yayasan bagaimana mengelola dari segi manajemen, fasilitas, litbang semuanya yang mengurusi yayasan sangat membantu dan kegiatan pembelajaran.

Kata kunci: Komunikasi Edukatif, Pemaduan Iman, Ilmu Dan Amal. 


\begin{abstract}
Andrianto, S.Pd, Nim, 17204010045, Implementation of Educational Communication in Integrating Faith, Science and Charity. Study of PAI Learning in Abu Bakar High School IT Yogyakarta. Thesis of Islamic Education Study Program (PI) Master Program (S2) Faculty of Tarbiyah and Teacher Training at UIN Sunan Kalijaga Yogyakarta.

Educative communication in the integration of faith, science and charity is communication carried out by two or more people whose education is educational. And this communication is very good to be mastered by the teacher for the sake of the fluency of the students.

The type of research used by the author is the type of qualitative research. The subjects of this study were PAI teachers and Abu Bakar High School IT students in Yogyakarta. Data collection is done by conducting observations, interviews, documentation and triangulation. Data analysis was carried out through four stages, namely: data clarification, data reduction, data interpretation and conclusion drawing. The technique of collecting data with the inductive method is to find as much data as possible and then conclude (general-specific)

The results of this study are: 1) the concept of characteristics and implementation of educational communication in the integration of faith, science and charity. Study of PAI Learning in Abu Bakar High School IT Yogyakarta, so a teacher must prepare teaching materials and a teacher must be able to explain and be able to master the material taught in the classroom, and a teacher must be able to provide examples in daily life so students easily understand the content of the material taught and the concepts in PAI learning refer to the JSIT curriculum and the merger of services for example by combining faith, science and charity in everyday life. 2) implementation of educational communication in the integration of faith, science and charity. PAI learning study at Abu Bakar High School IT Yogyakarta, the implementation is at 7:30 all students are already in class and reading the prayer and tadarus of the Qur'an, every Friday for those who are obliged to pray Friday, fasting Monday Thursday, eat together, hold a big day commemoration such as the lightning boarding school in the month of Ramadhon, social charity services and at Abu Bakar IT High School Yogyakarta do not know every day there are Islamic programs, Islamic art of calligraphy, recitations, hadroh, nasid, and there is religious mentoring and Boarding Scool, Full Day, Extracurricular, sports, robotics, journals, scouts (scouting), mentoring to support faith, science and charity. 3) the contribution of educational institutions in the implementation of educational communication in the integration of faith, science and charity. PAI learning studies at Abu Bakar High School IT Yogyakarta, the contribution of the concept is clearly KYM, namely noble foundation consortium escorts and manages the foundation from the concept of learning, Islam becomes the main spirit in Abu Bakar High School IT Yogyakarta so all teachers such as PAI teachers and from elementary, junior high, high school, the foundation is how to manage in terms of management, facilities, all $\mathrm{R} \& \mathrm{D}$ who take care of foundations are very helpful and learning activities.
\end{abstract}

Keywords: Educational Communication, Integration of Faith, Science and Charit 


\section{PEDOMAN TRANSLITERASI ARAB-LATIN}

Berdasarkan Surat Keputusan Bersama Menteri Agama RI dan Menteri

Pendidikan dan Kebudayaan RI Nomor 158/1987 dan 0543b/U/1987, tanggal 22

Januari 1988.

\section{A. Konsonan Tunggal}

\begin{tabular}{|c|c|c|c|}
\hline $\begin{array}{l}\text { Huruf } \\
\text { Arab }\end{array}$ & Nama & Huruf Latin & Keterangan \\
\hline 1 & Alif & tidak dilambangkan & tidak dilambangkan \\
\hline ب & $\mathrm{ba}^{\prime}$ & B & $\mathrm{Be}$ \\
\hline$ت$ & ta' & $\mathrm{T}$ & 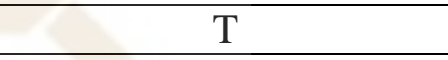 \\
\hline$\dot{H}$ & $\dot{s} a^{\prime}$ & $\dot{\mathrm{S}}$ & es (dengan titik di atas) \\
\hline ج & Jim & $\mathbf{J}$ & $\mathrm{Je}$ \\
\hline$\tau$ & ha & $\underline{h}$ & ha (dengan titik di bawah) \\
\hline$\dot{\tau}$ & Kha & Kh & ka dan ha \\
\hline د & Dal & $\mathrm{D}$ & De \\
\hline$\dot{j}$ & Zal & $\dot{\mathrm{Z}}$ & zet (dengan titik di atas) \\
\hline J & ra' & $\mathrm{R}$ & Er \\
\hline j & Zai & $\mathrm{Z}$ & Zet \\
\hline س & Sin & $\mathrm{S}$ & Es \\
\hline ش & Syin & Sy & es dan ye \\
\hline ص & șad & $\underline{s}$ & es (dengan titik di bawah) \\
\hline 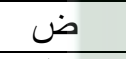 & dad & $\underline{d}$ & de (dengan titik di bawah) \\
\hline$b$ & ța' & t & te (dengan titik di bawah) \\
\hline ظ & za' & $\mathrm{z}$ & zet (dengan titik dibawah) \\
\hline$\varepsilon$ & 'ain & 6 & koma terbalik di atas \\
\hline$\dot{\varepsilon}$ & Gain & $\mathrm{G}$ & $\mathrm{Ge}$ \\
\hline$\dot{\theta}$ & fa' & $\mathrm{F}$ & Ef \\
\hline ق & Qaf & $\mathrm{Q}$ & Qi \\
\hline ك & Kaf & $\mathrm{K}$ & $\mathrm{Ka}$ \\
\hline J & Lam & $\mathrm{L}$ & $\mathrm{El}$ \\
\hline 5 & Mim & $\mathrm{M}$ & $\mathrm{Em}$ \\
\hline ن & Nun & $\mathrm{N}$ & $\mathrm{N}$ \\
\hline 9 & Wawu & $\mathrm{W}$ & $\mathrm{We}$ \\
\hline 0 & ha' & $\mathrm{H}$ & $\mathrm{Ha}$ \\
\hline 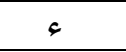 & Hamzah & & Apostrof \\
\hline ي & ya' & $\mathrm{Y}$ & $\mathrm{Ye}$ \\
\hline
\end{tabular}


B. Konsonan Rangkap karena Syaddah Ditulis Rangkap

\begin{tabular}{|c|c|c|}
\hline منعقدين & ditulis & muta'aqqidīn \\
ditulis & 'iddah \\
\hline
\end{tabular}

\section{Ta’ Marbutah}

1. Bila dimatikan ditulis $\mathrm{h}$

\begin{tabular}{|c|c|c|}
\hline هبة & ditulis & Hibbah \\
جزية & ditulis & Jizyah \\
\hline
\end{tabular}

(ketentuan ini tidak diperlakukan terhadap kata-kata Arab yang sudah terserap ke dalam bahasa Indonesia, seperti shalat, zakat, dan sebagainya, kecuali bila dikehendaki lafal aslinya).

Bila diikuti dengan kata sandang "al" serta bacaan kedua itu terpisah, maka ditulis dengan $h$.

\begin{tabular}{|l|l|l|}
\hline كر امه الأولياء & Ditulis & karāmah al-auliyā' \\
\hline
\end{tabular}

2. Bila ta' marbutah hidup atau dengan harkat, fathah, kasrah, dan dammah ditulis $\mathrm{t}$.

\begin{tabular}{|l|l|l|}
\hline زكاة الفطر & Ditulis & zakātul fiț̣i \\
\hline
\end{tabular}

D. Vokal Pendek

\begin{tabular}{|l|c|c|c|}
\hline & Kasrah & ditulis & $\mathrm{I}$ \\
& fathah & ditulis & $\mathrm{a}$ \\
& dammah & ditulis & $\mathrm{u}$ \\
\hline
\end{tabular}


E. Vokal Panjang

\begin{tabular}{|c|c|c|}
\hline fathah + alif & ditulis & A \\
جاهلية & ditulis & jāhiliyyah \\
fathah + ya' mati & ditulis & a \\
deسعى & ditulis & yas'ā \\
kasrah + ya' mati & ditulis & i \\
dammah + wawu mati & ditulis & karīm \\
ditulis & ditulis & furūd \\
\hline
\end{tabular}

F. Vokal Rangkap

\begin{tabular}{|c|c|c|}
\hline fathah + ya' mati & ditulis & $\mathrm{Ai}$ \\
fathah + wawu mati & ditulis & bainakum \\
dو & ditulis & au \\
& ditulis & qaul \\
\hline
\end{tabular}

G. Vokal Pendek yang Berurutan dalam Satu Kata Dipisahkan dengan Apostrof

\begin{tabular}{|c|c|c|}
\hline أعنت & ditulis & a'antum \\
أعدت & ditulis & u'idat \\
لئن شكرنم & ditulis & la'in syakartum \\
\hline
\end{tabular}

H. Kata Sandang Alif + Lam

a. Bila diikuti huruf Qamariyah

\begin{tabular}{|l|l|l|}
\hline القرأن| & ditulis & al-Qur'ān \\
القياس & ditulis & al-Qiyās \\
\hline
\end{tabular}


b. Bila diikuti huruf Syamsiyah ditulis dengan menggandakan huruf Syamsiyah yang mengikutinya, serta menghilangkan huruf (el)-nya.

\begin{tabular}{|c|c|c|}
\hline السماء & ditulis & as-samā' \\
& ditulis & asy-syams \\
\hline
\end{tabular}

I. Penulisan Kata-Kata dalam Rangkaian Kalimat

\begin{tabular}{|c|c|c|}
\hline ذوي الفروض & ditulis & zawi al-furūḍ \\
أهل السنة & ditulis & ahl as-sunnah \\
\hline
\end{tabular}

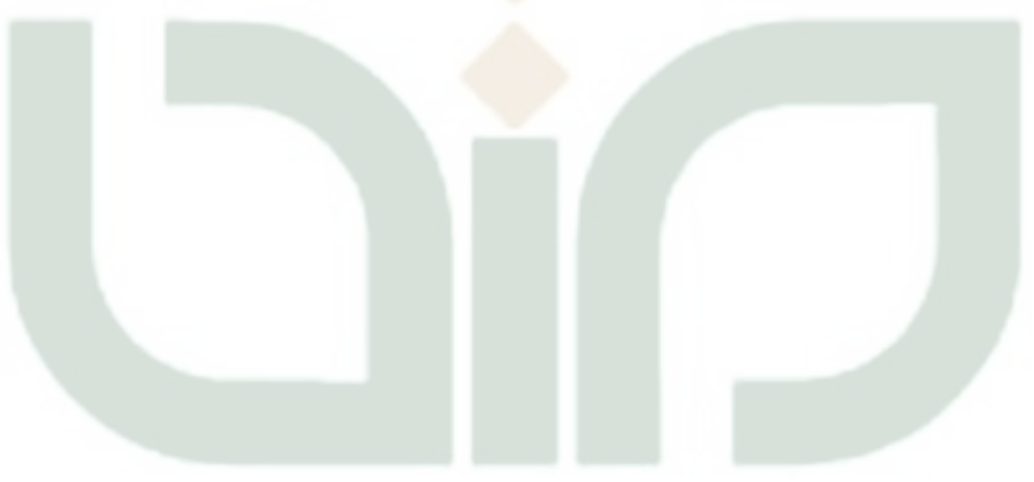




\section{KATA PENGANTAR}

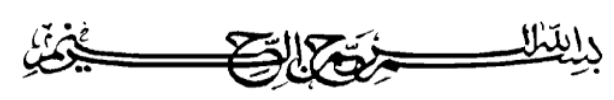

Alhamdulillah, segala puji dan syukur kehadirat Allah SWT yang telah melimpahkan rahmat, taufiq dan hidayah-Nya, sehingga penulis dapat menyelesaikan tesis ini dengan tanpa hambatan yang berarti. Shalawat serta salam semoga tetap terlimpahkan kepada junjungan Nabi besar kita yaitu Muhammad SAW, para keluarga, dan shabatnya yang telah membawa petunjuk kebenaran kepada seluruh manusia yakni agama Islam. Semoga di hari akhir nanti kita termasuk orang-orang yang mendapatkan syafaatnya. Amin.

Penyusunan tesis ini merupakan kajian singkat tentang implementasi komunikasi edukatif dalam pemaduan iman, ilmu dan amal. Studi pembelajaran PAI di SMA IT Abu Bakar Yogyakarta. Tesis ini penulis ajukan untuk memenuhi salah satu syarat guna memproleh gelar Magister Pendidikan konsentrasi Pendidikan Agama Islam Program Magister Fakultas Ilmu Tarbiyah dan Keguruan Universitas Islam Negeri Sunan Kalijaga Yogyakarta.

Berkat daya upaya serta bantuan, bimbingan maupun arahan dan instruksi dari berbagai pihak dalam proses penyusunan tesis ini, maka dengan segala kerendahan hati penulis mengucapkan rasa terima kasih dan penghargaan yang terhormat kepada:

1. Prof. Drs. Yudian Wahyudi, M.A., Ph.D., selaku Rektor UIN Sunan Kalijaga Yogyakarta.

2. Dr. Ahmad Arifin, M.Pd selaku Dekan Fakultas Ilmu Tarbiyah dan Keguruan UIN Sunan Kalijaga Yogyakarta 
3. Dr. Rajasa, M.Pd selaku Ketua Program Studi Pendidikan Islam (PI) Universitas Islam Negeri Sunan Kalijaga Yogyakarta.

4. Dr. Karwadi, M.Pd., selaku Sekretaris Program Pascasarjana Prodi Pendidikan Islam (PI) UIN Sunan Kalijaga Yogyakarta.

5. Dr. Usman, SS.M.Ag., selaku dosen pembimbing yang telah memberikan motivasi, bimbingan, dan arahan dengan penuh kesabaran, sehingga tesis ini dapat terselesaikan.

6. Seluruh dosen dan karyawan Prodi Pendidikan Islam (PI) Program Pascasarjana UIN Sunan Kalijaga Yogyakarta.

7. Ibu Nur Hasanah, M.Ag., selaku Guru PAI SMA IT Abu Bakar Yogyakarta.

8. Bapak Arif Utomo, S.Ag., selaku Guru PAI SMA IT Abu Bakar Yogyakarta.

9. Bapak Wawan Kuswanto, S.Ag., selaku Guru PAI SMA IT Abu Bakar Yogyakarta.

10. Seluruh Staf pegawai SMA IT Abu Bakar Yogyakarta yang telah memberikan arahan dalam penyelesaian tesis ini.

11. Ayahanda Kasiyo dan Ibu Sumilah, Kakakku tercinta Susiati, Rehana dan adikku Melati dan Keponakkan ku Andika Pratama dan Muhammad Iqbal Pratama, yang tersayang yang tak henti-hentinya memberikan dukungan moril maupun materil sehingga terselesaikan tesis ini tanpa kendala apapun.

12. Bapak Sukirman M.Si., selaku motivator penulis yang telah memberikan arahan penulis dalam melanjutkan perkuliahan di UIN Sunan Kalijaga Yogyakarta. 
13. Teman- teman Seperjuangan (Ahmad Wahyu Hidayat, Dwi Oktaria, Lisa Sulistiawati, Dwi Noviatul Zahra, Amrina Rosada, Anica, Aan Saputra, dan kelas PAI A1 dll) yang telah memberikan dukungan, saran dan semangat bagi penulis untuk menyelesaikan tesis ini.

Kepada semua pihak semoga amal baik yang telah diberikan dapat diterima oleh Allah SWT dan mendapatkan limpahan rahmat dari-Nya.Tiada kata yang pantas penulis ucapkan selain rasa terimakasih yang sebesar-besarnya dan rasa syukur atas selesainya penulisan tesis ini, terakhir kalinya penulis mohon maaf apabila ada kesalahan dalam penulisan tesis ini. Tesis ini masih jauh dari kesempurnaan, untuk itu kritik dan saran yang membangun sangat penulis harapkan demi perbaikan di masa mendatang.

Dengan memohon Ridho dari Allah SWT penulis berharap semoga tesis ini dapat bermanfaat bagi penulis khususnya dan bagi pembaca pada umumnya.

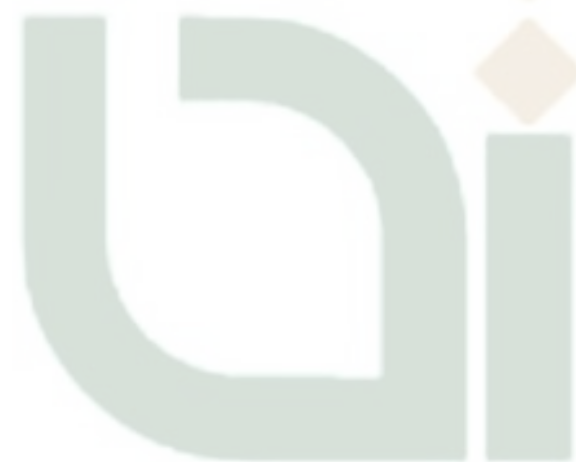

Yogyakarta, Oktober 2018

Hormat Saya

\section{ANDRIANTO, S.Pd. \\ NIM:17204010045}




\section{DAFTAR ISI}

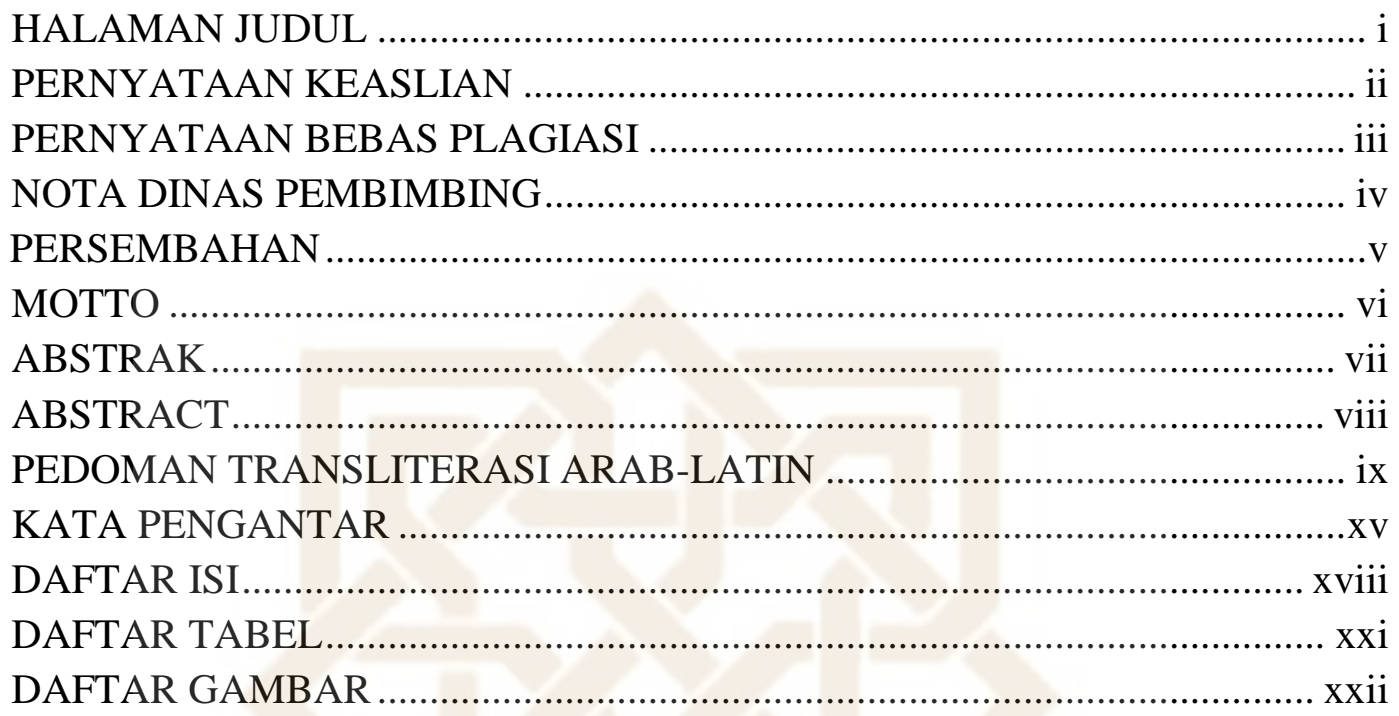

BAB I PENDAHULUAN

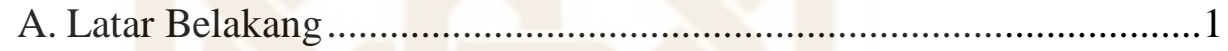

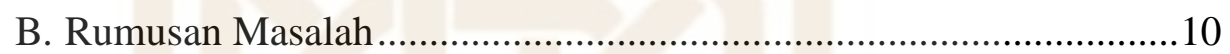

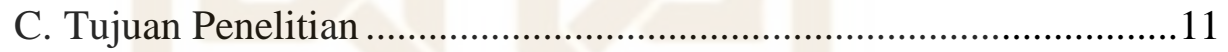

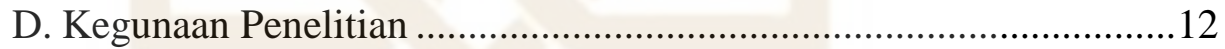

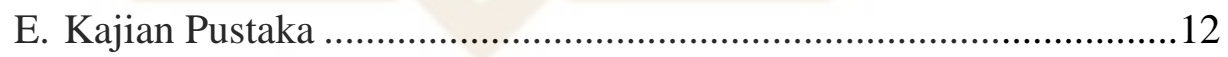

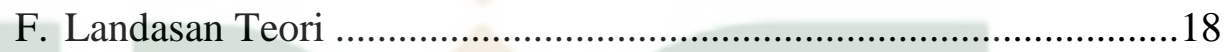

1. Pengertian Komunikasi Edukatif ................................................19

2. Model Komunikasi Edukatif .......................................................24

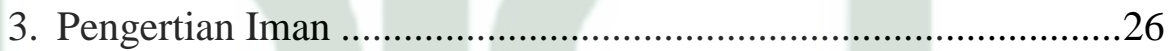

4. Pengertian Ilmu ........................................................................28

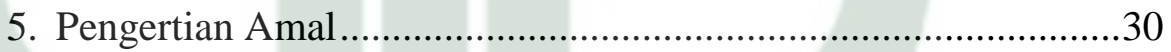

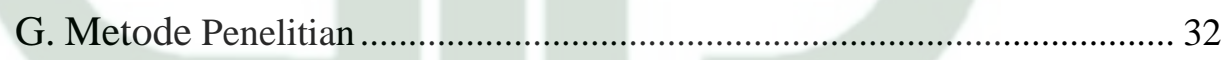

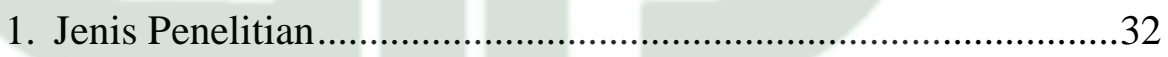

2. Pendekatan Penelitian ............................................................33

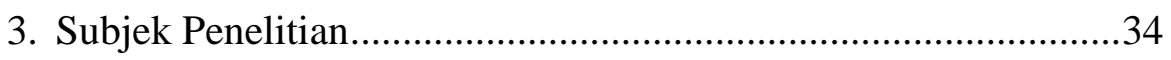

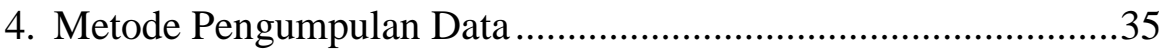

H. Sistematika pembahasan .............................................................42

BAB II KAJIAN TEORI

A. TINJAUAN MENGENAI KOMUNIKASI

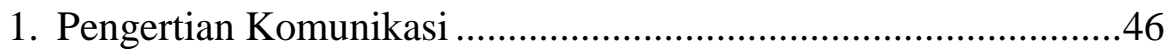

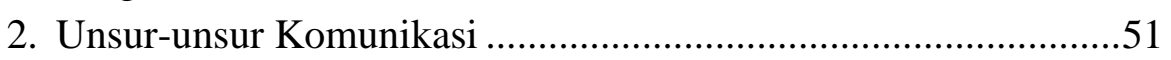

3. Sifat Komunikasi......................................................................61 
4. Tujuan Komunikasi

5. Faktor Penghambat Komunikasi

6. Unsur-unsur Unruk Mengatasi Hambatan Dalam Berkomunikasi

B. TINJAUAN MENGENAI KOMUNIKASI EDUKATIF

1. Pengertian Komunikasi Edukatif ..............................................76

2. Komponen-komponen Dasar Komunikasi Edukatif ...................80

3. Ciri-ciri Komunikasi Edukatif.................................................... 84

4. Pola Komunikasi Dalam Proses Belajar Mengajar ......................92

C. TINJAUAN MENGENAI KOMUNIKASI DALAM PROSES BELAJAR MENGAJAR .........................................................99

1. Tinjauan Mengenai Proses Belajar Mengajar ..............................99

a. Pengertian Belajar ..............................................................99

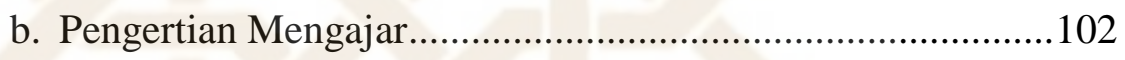

c. Pengertian Proses Belajar Mengajar.....................................105

d. Komponen-Komponen Dalam Proses Belajar Mengajar ......108

e. Tinjauan Komunikasi Edukatif Dalam Proses Belajar Mengajar.

D. KETERPADUAN IMAN, ILMU DAN AMAL

1. Iman Dalam Al-Qur'an

2. Ilmu Dalam Al-Qur'an

3. Amal Dalam Al-Qur'an.

BAB III GAMBARAN UMUM SMA IT ABU BAKAR YOGYAKARTA

1. Letak dan Keadaan Geografis.......................................................155

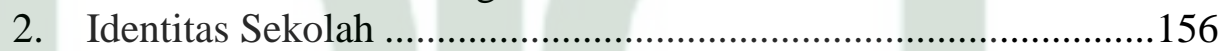

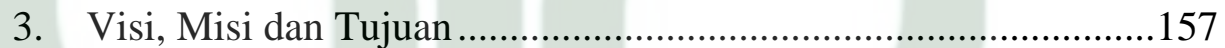

4. Sejarah Perkembangan, Dasar dan Tujuan Pendidikan................158

5. Struktur Organisasi .................................................................163

6. Keadaan Guru SMA IT Abu Bakar Yogyakarta ..........................168

7. Keadaan Siswa SMA IT Abu Bakar Yogyakarta ..........................170

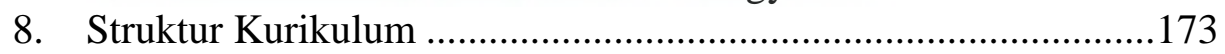

9. Standar Oprasional Prosedur Sekolah ......................................179

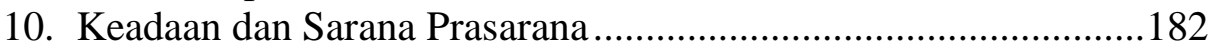

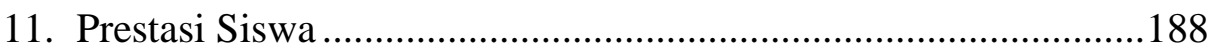

BAB IV KOMUNIKASI EDUKATIF DALAM PEMADUAN IMAN, ILMU DAN AMAL. STUDI PEMBELAJARAN PAI DI SMA IT ABU BAKAR YOGYAKARTA 
A. Konsep Komunikasi Edukatif Dalam Pemaduan Iman, Ilmu Dan Amal. Studi Pembelajaran PAI Di SMA IT Abubakar Yogyakarta .........................................................................192

B. Komunikasi Edukatif Dapat Menumbuhkan Iman, Ilmu Dan Amal. Studi Pembelajaran PAI Di SMA IT Abubakar Yogyakarta

C. Kontribusi Lembaga Pendidikan Dalam Komunikasi Edukatif Dalam Pemaduan Iman, Ilmu Dan Amal. Studi Pembelajaran PAI Di SMA IT Abubakar Yogyakarta.

BAB V PENUTUP

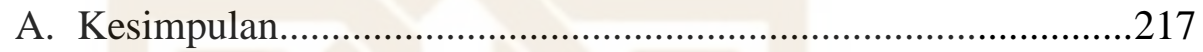

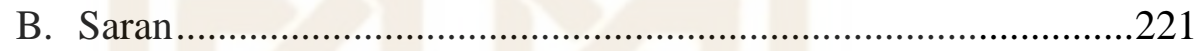

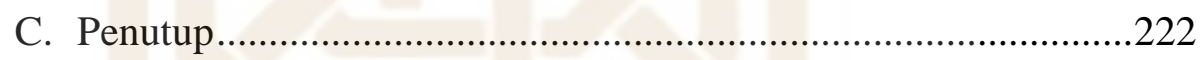

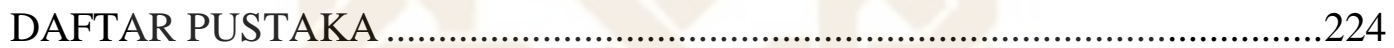

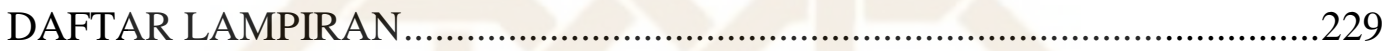

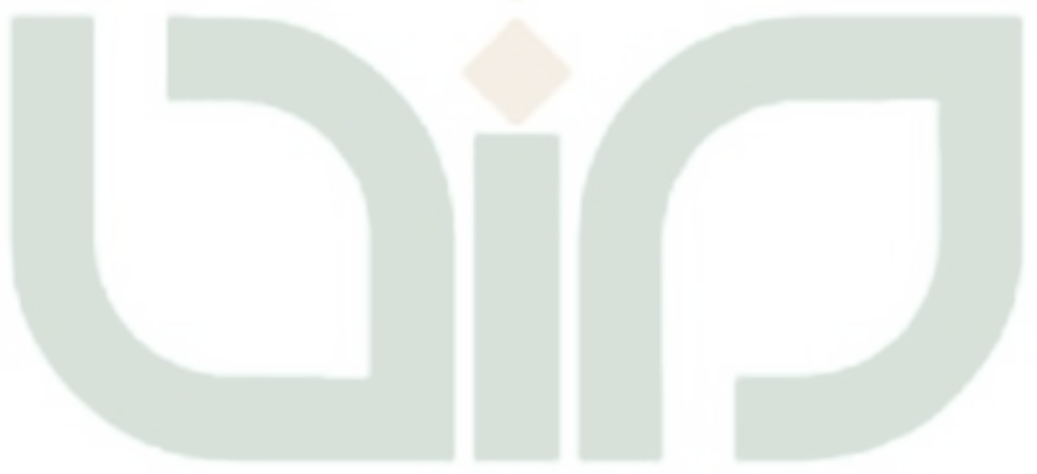




\section{DAFTAR TABEL}

Tabel. 1 Struktur Organisasi SMA IT Abu Bakar Yogyakarta 164

Tabel. 2 Daftar Jumlah Guru, Karyawan dan Pengurus Asrama SMA IT Abu Bakar Yogyakarta....................................................170

Tabel. 3 Jumlah Peserta Didik Boarding School SMA IT Abu Bakar Yogyakarta. 172

Tabel. 4 Struktur Kurikulum Program Sekolah ...........................................173

Tabel. 5 Struktur Mata Pelajaran Sekolah ......................................................175

Tabel. 6 Struktur Kurikulum Program Kepesantrenan .....................................177

Tabel. 7 Etrakulikuler di SMA IT Abu Bakar ................................................178

Tabel. 8 Sarana Prasarana Perpustakaan ............................................................184

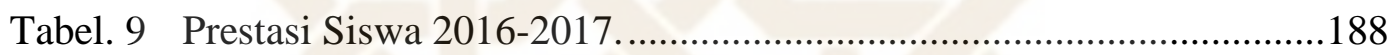

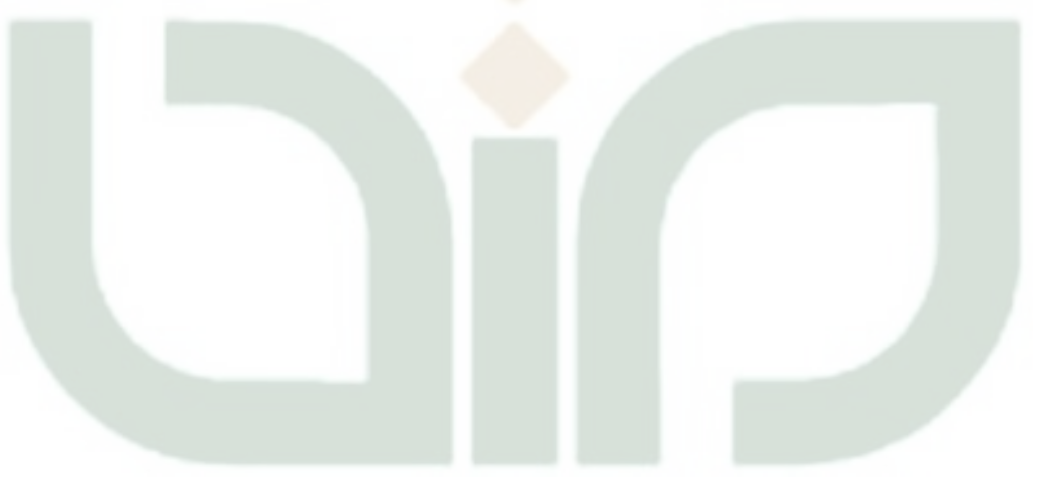




\section{DAFTAR GAMBAR}

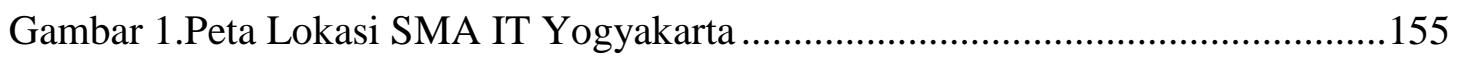

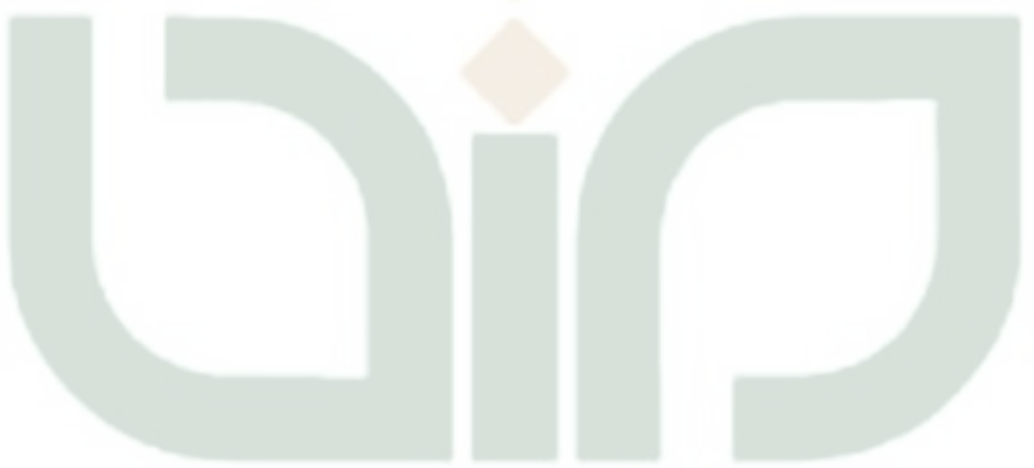




\section{BAB I}

\section{PENDAHULUAN}

\section{A. Latar Belakang Masalah}

Pendidikan adalah salah satu bentuk interaksi manusia, sekaligus tindakan sosial yang dimungkinkan berlaku melalui suatu hubungan kemanusian melalui peranan-peranan individu di dalamnya yang diterapkan melalui proses pembelajaran. Pembelajaran merupakan suatu proses interaksi antara pendidik dan peserta didik. Guru sebagai pendidik merupakan komponen terpenting dalam proses pembelajaran, karena guru berhubungan langsung dengan siswa sebagai subjek dan objek belajar. Pemberian pembelajaran yang efektif dibutuhkan unsur-unsur sistematis seperti guru, siswa, tujuan pembelajaran, bahan ajar, model pembelajaran, metode pembelajaran, media pembelajaran, dan suasana kelas yang terbentuk.

Menurut John Dewey menyatakan, bahwa pendidikan sebagai salah satu kebutuhan, fungsi sosial sebagai bimbingan, sarana pertumbuhan yang mempersiapkan dan membukakan serta membentuk disiplin hidup. ${ }^{1}$ Sedangkan Usman menyatakan bahwa: proses belajar mengajar merupakan suatu proses yang mengandung serangkaian perbuatan guru dan siswa atas dasar hubungan timbal balik yang berlangsung dalam situasi edukatif untuk mencapai tujuan tertentu. Hubungan timbal balik antara guru dan siswa merupakan syarat utama berlangsungnya proses belajar mengajar. ${ }^{2}$

\footnotetext{
${ }^{1}$ Jalaluddin, Teologi Pendidikan, (Jakarta, Raja Grafindo Persada: 2003), hlm. 67

${ }^{2}$ Usman, MohUzer, Menjadi Guru Profesional, (Bandung: RemajaRosdakarya, 2008), hlm. 114
} 
Komunikasi pada hakikatya adalah suatu proses sosial, yaitu sesuatu berlangsung atau berjalan antar manusia. Sebagai proses sosial, maka dalam komunikasi terjadi interaksi individual dengan lingkungannya. Inilah yang akhinya menyebabkan terjadinya proses perubahan perilaku dari tidak tahu menjadi tahu, dari tidak paham menjadi paham dan dari yang sebelumnya tidak mengacuhkan situasi masa depan menjadi berantusias sekali akan harapan-harapan positif pada masa yang akan datang.

Komunikasi adalah keterampilan yang sangat penting dalam kehidupan manusia, dimana dapat kita lihat komunikasi dapat terjadi pada setiap gerak langkah manusia. Manusia adalah makhluk sosial yang tergantung satu sama lain dan mandiri serta saling terkait dengan orang lain dilingkungannya. Satu-satunya alat untuk dapat berhubungan dengan orang lain dilingkungannya adalah komunikasi baik secara verbal maupun non verbal (bahasa tubuh dan isyarat yang banyak dimengerti oleh suku bangsa).

Komunikasi berhubungan dengan perilaku manusia dan kepuasan terpenuhinya kebutuhan berinteraksi dengan manusia-manusia lainnya. Setiap orang membutuhkan hubungan sosial dengan orang-orang lainnya dan kebutuhan ini terpenuhi melalui pertukaran pesan yang berfungsi sebagai jembatan untuk mempersatukan manusia yang satu dengan manusia lainnya, yang tanpa berkomunikasi akan terisolasi.

Pesan-pesan ini mengemukakan lewat perilaku manusia. Ketika kita berbicara, kita sebenarnya sedang berperilaku. Begitu juga ketika kita sedang melambaikan tangan, tersenyum, bermuka masam, menganggukkan kepala, 
atau memberikan suatu isyarat, kita sedang berperilaku. Sering perilakuperilaku ini merupakan pesan-pesan, yang mana pesan-pesan itu digunakan untuk mengkomunikasikan sesuatu kepada orang lain.

Dari sisi terminologi interaksi berarti hal saling melakukan aksi saling berhubungan dan mempengaruhi. Interaksi selalu berhubungan dengan istilah komunikasi. Komunikasi berasal dari kata communicate yang artinya berpartisipasi dan memberitahukan. Dalam proses komunikasi maka dikenal adanya unsur komunikan serta komunikator. ${ }^{3}$

Komunikasi edukatif merupakan komunikasi yang dilakukan oleh dua orang atau lebih yang bersifat mendidik. Dalam dunia pendidikan, segala aspek kegiatan khususnya di sekolah keberadaan komunikasi menjadi hal pokok dalam berjalannya seluruh kegiatan pembelajaran. Komunikasi pendidikan akan mampu menunjukkan arah proses pendidikan itusendiri.

Suryosubroto B. menyebut komunikasi eduktif ini dengan istilah interaksi edukatif. Menurut Suryosubroto B. "interaksi edukatif adalah hubungan timbal balik antara guru (pendidik) dan peserta didik (murid), dalam suatu sistem pengajaran”. Komunikasi edukatif merupakan hal penting dalam kegiatan belajar mengajar demi terwujudnya situasi pembelajaran yang baik. Melalui komunikasi edukatif antara guru dan peserta didik yang berjalan dengan baik, maka tujuan proses belajar mengajar dapat tercapai. ${ }^{4}$ Sedangkan menurut Johnson (1981) menunjukkan beberapa perannan yang disumbangkan

\footnotetext{
${ }^{3}$ Anwar Arifin, Ilmu Komunikasi, (Jakarta: PT Raja Grafindo Persada, 1995), hlm. 151

${ }^{4}$ SuryosubrotoB, Proses Belajar Mengajar Di Sekolah, ( Jakarta: PT Rineka Cipta, 2002), hlm. 156
} 
oleh komunikasi antar pribadi dalam rangka menciptakan kebahagiaan hidup manusia.

Pertama, komunikasi antar pribadi membantu perkembangan intelektual dan sosial kita. Kedua, identitas atau jati diri kita terbentuk dalam dan lewat komunikasi dengan orang lain. Ketiga, dalam rangka memahami realitas di sekeliling kita serta menguji kebenaran kesan-kesan dan pengertian yang kita miliki tentang dunia di sekitar kita, kita perlu membandingkannya dengan kesan-kesan dan pengertian orang lain tentang realitas orang lain. Keempat, kesehatan mental kita sebagian besar juga ditentukan oleh kualitas komunikasi atau hubungan kita dengan orang lain, lebih-lebih orang-orang yang merupakan tokoh-tokoh yang signifikan (significant figures) dalam hidup kita. ${ }^{5}$ Komunikasi menurut penulis adalah alat untuk berinteraksi antara manusia dengan manusia lain sehingga dalam berinteraksi ada hubungan komunikasi edukatif yang baik, dengan adanya komunikasi edukatif yang baik maka hubungan antara manusia dengan manusia lain bisa hidup rukun, aman dan damai.

Dalam pembelajaran di SMA IT Abu Bakar Yogyakarta peneliti melihat langsung di kelas X1 mia1 saat pembelajaran Pendidikan Agama Islam berlangsu, sebelum pembelajaran di mulai ustadzah mengucapkan salam dan membuka pembelajaran dengan tema sejarah fase mekah. Sebelum masuk ke materi ustadzah bertanya kepada siswa siapa yang tau sejarah fase mekah di situ komunikasi edukatif berjalan dengan baik, guru dan siswa saling

\footnotetext{
${ }^{5}$ Muh Nurul Huda, Komunikasi Pendidikan Teori Dan Aplikasi Komunikasi Dalam Pembelajaran, (Tulung Agung: STAIN Press, 2013), hlm. 4
} 
merespon dengan baik. Dari segi pembelajaran ustadzah Nurhasanah sangat menguasai materi, menggunakan metode ceramah, proyektor dan laptop dengan baik. Akan tetapi di dalam pembelajaran ustadzah Nurhasanah kurang menguasai kelas dimana saat pembelajaran berlangsung siswa banyak mengobrol dengan teman sebangku, ada yang ribut dan ada yang memperhatikan ustadzah Nurhasanah di depan yang menjelaskan materi sejarah fase mekah. ${ }^{6}$

Dalam pembelajaran sejarah fase mekah ustadzah Nurhasanah terfokus pada siswa yang di depan sehingga siswa yang di belakang sibuk sendiri dengan teman sebangkunya, ada yang teriak-teriak ketika pembelajaran berlanjut sehingga dalam pembelajaran di kelas seperti pasar. Ustadzah Nurhasanah juga memadukan iman, ilmu dan amal dalam pembelajaran di kelas, akan tetapi siswa ada yang belum menjalankan apa itu iman, ilmu dan amal, ketika pembelajaran berlangsung terdengar suara adzan siswa tidak mengindahkan ustadzah Nurhasanah memberikan himbauan untuk diam sejenak ketika suara adzan berkumandang, tetapi ada beberapa siswa masih ngobrol, jalan-jalan di kelas dan rame dengan teman sebangkunya. ${ }^{7}$ Pada proses pembelajaran, komunikasi menjadi hal yang penting agar tujuan pembelajaran dapat tercapai. Namun beberapa guru mengalami problemproblem komunikasi dalam proses pembelajaran tersebut. Problema tersebut dapat dirinci sebagai berikut:

\footnotetext{
${ }^{6}$ Observasi kelas XI MIA ${ }^{1}$, pada hari Selasa, tanggal 23 Oktober 2018 di SMA IT Abu Bakar Yogyakarta

${ }^{7}$ Observasi kelas XI MIA ${ }^{1}$, pada hari Selasa, tanggal 23 Oktober 2018 di SMA IT Abu Bakar Yogyakarta
} 
Pertama, ada beberapa guru yang kurang disukai siswa. Kedua, guru kurang mampu berkomunikasi dengan siswa. Ketiga, guru kurang mampu tampil secara optimal dalam menjalankan tugasnya. Keempat, guru kurang memberikan motivasi kepada peserta didik. Kelima, guru monoton dalam pembelajaran. Keenam, media yang kurang sesuai atau kurang memadai. Ketuju, guru menganggap peserta didik sebagai objek, bukan sebagai subjek. Kedelapan, guru menjadi sumber utama. Dari problem-problem di atas penulis bisa menyimpulkan bahwa kurangya komunikasi edukatif dalam pendidikan di sekolah antara guru dan murid sehingga komunikasi edukatif kurang efektif.

Penulis temui di lapang hubungan komunikasi edukatif dan pemaduan iman, ilmu dan amal di SMA IT Abu Bakar Yogyakarta, sudah berjalan tetapi kurang efektif di kelas ataupun di luar kelas sehingga komunikasi edukatif dalam pemaduan iman, ilmu dan amal, kurang efektif dalam pembelajaran. Komunikasi edukatif dalam pemaduan iman, ilmu dan amal belum tercapai sesuai dengan visi dan misi SMA IT Abu Bakar Yogyakarta.

Dari wawancara dengan Ibu Nur Hasanah, M.Ag, bahwasanya SMA IT Abu Bakar adalah sekolah yang mempunyai visi dan misi dalam pemaduan iman, ilmu dan amal. ${ }^{8}$ Oleh karena itu penulis tertarik untuk meneliti "Implementasi Komunikasi Edukatif Dalam Pemaduan Iman, Ilmu Dan Amal Studi Pembelajaran PAI Di SMA IT Abu Bakar Yogyakarta”.

\section{B. Rumusan Masalah}

\footnotetext{
${ }^{8}$ Nur Hasanah, Kepala Sekolah SMA IT Abu Bakar Yogyakarta, Wawancara, 9 April 2018
} 
1. Bagaimana konsep dan implementasi komunikasi edukatif dalam pemaduan iman, ilmu dan amal studi pembelajaran PAI di SMA IT Abu Bakar Yogyakarta?

2. Bagaimana implementasi komunikasi edukatif dalam pemaduan iman, ilmu dan amal studi pembelajaran PAI di SMA IT Abu Bakar Yogyakarta?

3. Apa kontribusi lembaga pendidik dalam implementasi komunikasi edukatif dalam pemaduan iman, ilmu dan amal studi pembelajaran PAI di SMA IT Abu Bakar Yogyakarta?

\section{Tujuan Penelitian}

1. Tujuan Penelitian

Sebagaimana rumusan masalah yang disebutkan diatas, maka tujuan penelitian ini adalah:

a. Untuk mengetahui konsep dan implementasi komunikasi edukatif dalam pemaduan iman, ilmu dan amal studi pembelajaran PAI di SMA IT Abu Bakar Yogyakarta.

b. Untuk mengetahui implementasi komunikasi edukatif dalam pemaduan iman, ilmu dan amal studi pembelajaran PAI di SMA IT Abu Bakar Yogyakarta.

c. Untuk mengetahui kontribusi lembaga pendidik dalam implementasi komunikasi edukatif dalam pemaduan iman, ilmu dan amal studi pembelajaran PAI di SMA IT Abu Bakar Yogyakarta.

\section{Kegunaan Penelitian}


1. Secara teoritis, diharapkan penelitian ini dapat menyumbangkan khazanah keilmuan khususnya tentang implementasi komunikasi edukatif dalam pemaduan iman, ilmu dan amal dalam pembelajaran PAI.

2. Secara praktis, sebagai bahan pertimbangan bagi para pemegang kebijakan dan para stakeholder dalam pengembangan pendidikan di masa sekarang dan masa yang akan datang. Memberikan sumbangan pemikiran bagi perkembangan pendidikan baik dalam ilmu pengetahuan agama maupun pengetahuan umum di Sekolah SMA IT Abu Bakar Yogyakarta khususnya.

\section{E. Kajian Pustaka}

Tinjauan pustaka atau kajian pustaka merupakan salah satu cara untuk mengetahui keabsahan suatu karya ilmiah, disamping itu juga untuk menghindari maksud duplikasi dan untuk membuktikan kalau topik yang diangkat oleh penyusun belum pernah diteliti sebelumnya oleh peneliti lainnya. Untuk mendukung keabsahan penyusunan tesis ini, peneliti berusaha melakukan peninjauan terhadap tesis, jurnal dan skripsi yang berkaitan tentang implementasi komunikasi edukatif dalam pemaduan iman, ilmu dan amal. Studi pembelajaran PAI di SMA IT Abu Bakar Yogyakarta. Tujuannya untuk mengetahui apakah tema yang akan diteliti sudah perna diteliti atau tidak. Adapun karya-karya yang dapat peneliti kemukakan diantaranya:

Pertama,Jurnal yang ditulis M. Saekan Muchith dalam penelitian nya yang berjudul, Membangun Komunikasi Edukatif, Jurnal At-Tarbiyah, Jurnal 
Komunikasi Penyiaran Islam vol 3, No.1 Juni 2015. ${ }^{9}$ Adapun hasil penelitian ini, yaitu Komunikasi edukatif adalah pola komunikasi yang dilakukan kepada pihak pihak lain yang didasarkan atas semangat untuk meraih kemanfaatan secara individual dan sosial dengan tetap memperhatikan asas kepantasan, ketepatan dan kearifan. Komunikasi edukatif sangat tepat dijadikan metode dakwah khususnya di era teknologi dan semakin berkembangnya dinamika masyarakat yang menyebabkan banyaknya problem kehidupan masyarakat.

Kedua, Jurnal yang ditulis, Zuradah Binti Othman, Dr. Hasan Alzan Binti Ali Dalam Penelitian Yang Berjudul, Pendidikan Integratif Dalam Islam: KesepaduanIman,Ilmu Dan Amal, Jurnal Al Muqaddimah Bill 2 (2) 2004. ${ }^{10}$ Adapun hasil penelitian ini adalah konsep integratif mencerminkan hakikat sifat ilmu itu sendiri. Ilmu tidak pernah bersifat sekular, terpisah dan sempit. Sifat ilmu tidak terbatas kepada akal dan pancaindera saja. Ilmu yang dipamerkan oleh Allah s.w.t kepada kita cukup luas. Ilmu itu saling berkait dan berpadu dengan begitu seimbang dan harmoni. Inilah yang melambangkan kebesaran Allah s.w.t. Dengan wujudnya konsep integratif dalam pendidikan, memberikan kita satu asas yang benar untuk mempelajari dan memahami tanda-tanda kebesaran Allahs.w.t.

Ketiga, Jurnal Yang Ditulis Tri Suzanti, Interaksi Edukatif Dalam Proses Belajar Mengajar Sosiologi Di SMA Negeri 1 Bungoro Kabupaten

\footnotetext{
${ }^{9}$ M. Saekan Muchith, Membangun Komunikasi Edukatif, Jurnal At-Tarbiyah, Jurnal Komunikasi Penyiaran Islam vol 3, No.1 Juni 2015

${ }^{10}$ Zuradah Binti Othman, Dr. Hasan Alzan Binti Ali, Pendidikan Integratif Dalam Islam: KesepaduanIman,Ilmu Dan Amal, Jurnal Al Muqaddimah Bill 2 (2) 2004
} 
Pangkep Jurnal Sosialisasi Vol 4 Edisi 1, Maret 2017. ${ }^{11}$ Penelitian ini bertujuan untuk mengetahui 1) pelaksanaan interaksi edukatif yang dilakukan oleh guru pada proses belajar mengajar sosiologi di SMA Negeri 1 Bungoro 2 ) Dampak interaksi edukatif dalam proses pembelajaran sosiologi di SMA Negeri 1 Bungoro Kabupaten Pangkep. Dampak pelaksanaan interaksi edukatif melalui komunikasi yang beranekaragam memberikan dampak positif bagi proses pembelajaran sosiologi siswa di kelas XI IPS 3 dan XII IPS 3 yakni mampu membangun perhatian belajar sosiologi siswa, siswa lebih termotivasi, dan antusias untuk belajar sosiologi karena metode serta model pembelajaran yang dilakukan oleh guru tidak monoton.

Keempat, Jurnal yang ditulis Nurdin Manyak, Posisi Pendidikan Islam Dalam Mengembangkan Ilmu, Iman Dan Amal Shaleh, Jurnal Mudarrisuna, Vol 3, Nomor 2 Juli-Desember 2013. ${ }^{12}$ Adapun hasil penelitian ini bertujuan untuk mengetahui ilmu, iman dan amal shaleh merupakan tiga unsur yang diharapkan teraktualisasi dalam pendidikan Islam dengan menempatkan ketiga unsur tersebut dalam tujuan, materi pelajaran yang mengarahkan subjek didik menuju kearah yang harmonis anatara lain, ilmu, iman dan amalshaleh. Pendidikan Islam sangat memperhatikan agar ilmu, iman dan amal shaleh tumbuh dan berkembang pada diri subjek didik, sehingga pendidikan benarbenar efektif dalam rangka peningkatan ketika unsur utama tujuan keberadaan subjek didik.

\footnotetext{
${ }^{11}$ Tri Suzanti, Interaksi Edukatif Dalam Proses Belajar Mengajar Sosiologi Di Sma Negeri 1 Bungoro Kabupaten Pangkep Jurnal Sosialisasi Vol 4 Edisi 1, Maret 2017

${ }^{12}$ Nurdin Manyak, Posisi Pendidikan Islam Dalam Mengembangkan Ilmu, Iman Dan Amal Shaleh, Jurnal Mudarrisuna, Vol 3, Nomor 2 Juli-Desember 2013
} 
Kelima, Jurnal yang ditulis Ety Nur Inah, Peran Komunikasi Dalam Interaksi Guru Dan Siswa, Jutrnal Al-Ta'dib Vol 8 No.2, Juli-Desember 2015. ${ }^{13}$ Adapun hasil penelitian ini bertujuan untuk mengetahui Pertama, komunikasi sebagai aksi atau komunikasi satu arah, yaitu guru sebagai pemberi aksi dan siswa sebagai penerima aksi. Guru aktif, siswa pasif, mengajar dipandang sebagai kegiatan menyampaikan bahanpelajaran. Kedua, komunikasi sebagai interaksi atau komunikasi dua arah, yaitu guru bisa berperan sebagai pemberi aksi atau penerima aksi. Sebaliknya siswa, bisa penerima aksi bisa pula pemberi aksi. Dialog akan terjadi antara guru dengansiswa.Ketiga, komunikasi sebagai transaksi atau komunikasi banyak arah, yaitu komunikasi tidak hanya terjadi antara guru dengan siswa, tetapi juga antara siswa dengan siswa. Siswa dituntut aktif dari pada guru. Siswa, seperti halnya guru, dapat berfungsi sebagai sumber belajar bagi siswalain.

Dari berbagai jurnal dan hasil penelitian lain yang telah peneliti amati belum ada mahasiswa yang meneliti tentang implementasi komunikasi edukatif dalam pemaduan iman, ilmu dan amal. Studi pembelajaran PAI di SMA IT Abu Bakar Yogyakarta. Adapun yang membedakannya adalah peneliti lebih terfokus kepada metode pembelajaran yang digunakan guru PAI dalam implementasi komunikasi edukatif dalam materi-materi PAI dan pemaduan iman, ilmu dan amal dalam studi PAI dengan disiplin ilmu yang lain di sekolah SMA IT Abu Bakar Yogyakarta.

${ }^{13}$ Ety Nur Inah, Peran Komunikasi Dalam Interaksi Guru Dan Siswa, Jutrnal Al-Ta'dib Vol 8 No.2, Juli-Desember 2015. 


\section{F. Kerangka Teoritik}

Kerangka teoritik disini adalah penjelasan tentang teori yang relevan dengan permasalahan yang akan diteliti oleh penyusun, tujuannya sebagai rujukan atau bahan acuan untuk penyusun dalam menganalisis data yang diperoleh. Adapun konsep atau pendekatan yang akan digunakan adalah pendekatan implementasi komunikasi edukatif dalam pemaduan iman, ilmu dan amal. Studi pembelajaran PAI di SMA IT Abu Bakar Yogyakarta.

\section{Pengertian Komunikasi Edukatif}

Komunikasi edukatif merupakan komunikasi yang dilakukan oleh dua orang atau lebih yang bersifat mendidik. Dalam dunia pendidikan, segala aspek kegiatan khususnya di sekolah keberadaan komunikasi menjadi hal pokok dalam berjalannya seluruh kegiatan pembelajaran. Komunikasi pendidikan akan mampu menunjukkan arah proses pendidikan itu sendiri.

Suryosubroto B. menyebut komunikasi eduktif ini dengan istilah interaksi edukatif. Menurut Suryosubroto B. "interaksi edukatif adalah hubungan timbal balik antara guru (pendidik) dan peserta didik (murid), dalam suatu sistem pengajaran". Komunikasi edukatif merupakan hal penting dalam kegiatan belajar mengajar demi terwujudnya situasi pembelajaran yang baik. Melalui komunikasi edukatif antara guru dan 
peserta didik yang berjalan dengan baik, maka tujuan proses belajar mengajar dapattercapai. ${ }^{14}$

Pawit M. Yusuf menjelaskan definisi komunikasi yaitu, "Komunikasi pendidikan adalah komunikasi yangmerambah atau menyentuh dunia pendidikan". Komunikasi pendidikan dirancang secara khusus untuk meningkatkan nilai tambah bagi para peserta didik dalam berbagai bidang kehidupan. Komunikasi yang berlangsung dalam dunia pendidikan harus mampu mendidik dan membimbing peserta didik serta bersifat edukatif. ${ }^{15}$ Selain itu definisi komunikasi atau interaksi edukatif menurut Winarno Surakhmad yaitu "Interaksi yang terjadi dalam situasi edukatif, yakni interaksi yang berlangsung dalam ikatan tujuanpendidikan". 16

Definisi komunikasi edukatif atau interaksi edukatif menurut Syaiful Bahri Djamarah yaitu " hubungan dua arah antara guru dan anak didik dengan sejumlah norma sebagai mediumnya untuk mencapai tujuan pendidikan". ${ }^{17}$ Selanjutnya, menurut Ngainun Naim, "komunikasi pendidikan dapat diartikan sebagai komunikasi yang terjadi dalam suasana pendidikan. Dengan demikian, komunikasi pendidikan adalah proses perjalanan pesan atau informasi yang merambah bidang atau peristiwa-

\footnotetext{
${ }^{14}$ SuryosubrotoB, Proses Belajar Mengajar Di Sekolah, (Jakarta: PT Rineka Cipta, 2002), hlm. 156

${ }^{15}$ Pawit M. Yusuf, Komunikasi Instruksional, Teori dan Praktik, (Jakarta: Bumi Aksara, 2010), hlm. 2

${ }^{16}$ Winarno Surakhmad, Pengajaran Micro Pendekatan Praktis Menyiapkan Pendidik Profesional, (Jogjakarta: Tiara Wacana, 2005), hlm. 7

${ }^{17}$ Syaiful Bahri Djamarah, Guru dan Anak Didik dalam Interaksi Edukatif, (Jakarta: PT Rineka Cipta, 2005), hlm. 11
} 
peristiwa pendidikan". ${ }^{18}$ Sehingga kegiatan komunikasi dalam dunia pendidikan dikendalikan dan dikondisikan untuk mencapai tujuan-tujuan pendidikan. Proses pembelajaran pada hakikatnya merupakan suatu proses komunikasi, yaitu penyampaian pesan dari komunikator kepada komunikan. Pesan yang disampaikan dalam komunikasi edukatif yaitu berupa isi atau ajaran atau nilai-nilai dan budaya yang dituangkan dalam proses pembelajaran antara guru dan pesertadidik.

Pendidikan sering dimaknai sebagai suatu bentuk transmisi nilai atau budaya dari guru (pendidik) kepada peserta didik (terdidik) atau dari orang tua kepada anak-anaknya. Pendidikan sebagai suatu upaya transmisi nilai dari seseorang kepada orang lain. Proses transmisi nilai tersebut terjadi melalui komunikasi antara pendidik (guru) dan peserta didik atau antara orang tua dan anak-anaknya. Komunikasi yang terjadi dalam rangka transmisi nilai ini sesungguhnya merupakan suatu komunikasi edukatif. Tidak semua bentuk komunikasi merupakan komunikasi edukatif atau komunikasi pendidikan. Aspek yang paling substansial dalam komunikasi pendidikan yaitu terjadinya transmisi nilai.

Selama kegiatan belajar mengajar guru tidak akan pernah terlepas dari proses komunikasi. Komunikasi yang terjadi tersebut diharapkan tidak hanya sebatas proses penyampaian materi pelajaran saja, melainkan juga adanya proses transmisi nilai. Ketika proses kegiatan belajar mengajar, penerapan komunikasi edukatif menjadi penting dan memegang peran

\footnotetext{
${ }^{18}$ Ngainun Naim, Dasar-dasar Komunikasi Pendidikan, (Yogyakarta: Ar- Ruzz Media, 2011), hlm. 27
} 
yang signifikan guna tercapainya tujuan pembelajaran. Nilai-nilai yang disampaikan oleh seorang pendidik merupakan salah satu dari komponen komunikasi, yaitu merupakan komponen pesan. Efektivitas komunikasi edukatif ditandai oleh adanya kesesuaian antara nilai-nilai sebagai isi pesan dan dampak yang diinginkan oleh pendidik. Semakin sesuai nilainilai yang diterima oleh peserta didik dan semakin jelasdampak yang diinginkan oleh pendidik, maka semakin efektif komunikasi edukatif yang terjadi. Komunikasi edukatif yang berjalan secara efektif akan memungkinkan terserapnya makna pendidikan secara lebih utuh dan mendalam. Dengan demikian, komunikasi edukatif merupakan suatu hal yang sangat penting dan signifikan dalam menunjang keberhasilan pembelajaran.

2. Model Komunikasi Edukatif

a. Komunikasi Verbal

Komunikasi verbal adalah komunikasi yang menggunakan simbolsimbol verval, baik secara lisan maupun tertulis. Simbol atau pesan verbal adalah semua jenis simbol yang menggunakan satu kata atau lebih. ${ }^{19}$ Menurut Herlina komunikasi verbal di tandai dengan ciri-ciri sebagai berikut:

1) Disampaikan secara lisan atau bicara atau tulisan.

2) Proses komunikasi eksplinsit dan cenderung dua arah.

3) Kualitas proses komunikasi seringkali ditentukan oleh

${ }^{19}$ Mulyana, Ilmu Komunikasi Suatu Pengantar, (Bandung:PT Remaja Rosdakarya), hlm. 
komunikasi verbal. $^{20}$

b. Komunikasi Nonverbal

Komunikasi nonverbal adalah kegiatan pengoperan atau penyampaian pesan yang tidak menggunakan lambang komunikasi bahasa lisan. Komunikasi nonverbal adalah semua aspek komunikasi selain kata-kata, yang meliputi tidak hanya gerakan dan bahasa tubuh, tetapi juga bagaimana kita mengucapkan kata-kata: infleksi, jeda, nada, volume dan aksen.tanda-tanda nonverbal terlihat dari tampilan wajah dan gerakan tangan. ${ }^{21}$ Jenis-jenis komunikasi verbal menurut Jandt adalah sebagai berikut:

1) Kedekatan (Proxemics)

Istilah ini berasal dari Edward Hall yang berasal dari kata Proximity (kedekatan) untuk menunjukkan adanya ruang atau teritorial baku dan ruang personal dalam berkomunikasi.

2) Kinestik

Istilah ini digunakan untuk menunjukkan gerak-gerik atau sikap tubuh (gestures), geak tubuh (body movement), ekspresi wajah, dan kontak mata.

\section{3) Kronemik}

Istilah ini berkaitan dengan waktu. Ada yang memandang waktu itu berjalan linier atau mengikuti garis lurus yang bergerak

\footnotetext{
${ }^{20}$ Herlina, Komunikasi Verbal, Makalah mata Kuliyah Ilmu Pernyataan Jurusan Psikologi, (Bandung: Universitas Pendidikan Indonesia (UPI), 2013), hlm. 1

${ }^{21}$ Kurniawati , Komunikasi Antar Pribadi: Konsep dan Teori Dasar, (Yogyakarta: Graha Ilmu, 2014), hlm. 35
} 
dari titik awal menuju titik akhir. Ada juga yang memandang waktu itu siklikal, artinya berputar untuk kembali pada titik awal. ${ }^{22}$

\section{Pengertian Iman}

Secara etimologi Iman berasal dari kata amana-yu'minu-imanan yang artinya percaya. ${ }^{23}$ Dalam bahasa Indonesia iman adalah kepercayaan atau keyakinan. ${ }^{24}$ Akidah dalam pengertian terminologi adalah iman, keyakinan yang menjadi pegangan hidup bagi setiap pemeluk agama Islam. Oleh karena itu, akidah selalu ditautkan dengan rukun iman atau arkan al-iman yang merupakan asas bagi ajaran Islam. $^{25}$ Iman ialah pengakuan dengan hati, pengucapan dengan lidah dan pengalaman dengan anggotabadan. ${ }^{26}$

Dari pengertian di atas dapat disimpulkan bahwa iman adalah kita mempercayai atau meyakini di dalam hati, di ucapkan dengan lisan dan di aplikasikan melalui perbuatan yang menjadi pegangan hidup bagi setiap pemeluknya untuk mencapai kebahagiaan di dunia maupun kebahagiaan di akhirat kelak.

Iman Menurut Ibnu Taymiyyah yang dikutip oleh Zuhdiyah dalam bukunya Psikologi Agama mengungkapkan ada tiga bentuk keyakinan atau kepercayaan manusia, 'ilm al-yaqin, 'ain al-yaqin dan haqq al-yaqin. 'Ilm

\footnotetext{
${ }^{22}$ Iriantara, Komunikasi Antar Pribadi, (Tangerang: Universitas Terbuka, 2014), hlm. 110

${ }^{23}$ M. Kasir Ibrahim, Kamus Arab Indonesia; Indonesia Arab, (Surabaya : PT. Apollo Lestari, 2008), hlm. 627 2002), hlm.37

${ }^{24}$ Aditya Nagara, Kamus Praktis Bahasa Indonesia, (Surabaya: PT. Bintang Usaha Jaya,

${ }^{25}$ Zainuddin Ali, Pendidikan Agama Islam, (Jakarta: PT. Bumi Aksara, 2011), Cet ke-IV, hlm. 2

26 Syahminan Zaini, Tinjauan Analisis Tentang Iman, Islam dan Amal, (Malang: KalamMulia, 2006), Cet ke-III, hlm. 6
} 
al-yaqin adalah keyakinan berdasarkan kepada pendengaran, pemberitaan atau khabar. 'Ain al-yaqin adalah keyakinan berdasarkan kepada penglihatan mata dengan menyaksikan sediri. Haqq al-yaqin adalah keyakinan yang timbul karena ikut serta mengalami sendiri, merasakan dan menghayati. ${ }^{27}$

Menurut Ibnu Taymiyyah di atas dapat disimpulkan bahwa ada tiga bentuk keyakinan yang dimiliki manusia. 'ilm al-yaqin, 'ain al-yaqin dan haqq al-yaqin. Apabila dalam jiwa seorang muslim telah tumbuh haqq alyaqin kepada Allah SWT, yakin terhadap keesaan-Nya, keagungan-Nya dan sebagainya, maka dia telah mencapai pada derajat yang paling tinggi, yakni derajat taqwa.

Indikator orang beriman yaitu sebagai berikut :

a. Orang-orang yang khusyu' dalam shalat.

b. Menjauhkan diri dari hal yang tiadaberguna.

c. Menunaikan zakat.

d. Menjaga kemaluannya

e. Memelihara amanat dan janji. ${ }^{28}$

4. Pengertian Ilmu

Kata Ilmu dengan berbagai bentuknya disebutkan dalam AlQur" an sebanayak 854 kali. Kata ini dipakai dalam arti proses pencapaian pengetahuan dan objek pengetahuan. „Ilm dari segi bahasa berarti kejelasan. Segal yang terbentuk dari akar kata „Ilm memiliki ciri kejelasan. Misalnya, kata alam(bendera),,,ulmat (bibir sumbing), ,a 'lam (gunung- gunung), ,alamat (alamat), dan lain sebagainya. Ilmu adalah

\footnotetext{
${ }^{27}$ Zuhdiyah, Psikologi Agama, (Yogyakarta : Pustaka Felicha, 2012), hlm. 186

${ }^{28}$ Ibid., hlm. 186
} 
pengetahuan yang jelas tentang sesuatu. Meskipun demikian, kata ,ilm berbeda dengan kata ,arafa (mengetahui), ,, arif (orang yang mengetahui), dan ma'rifah (pengetahuan). ${ }^{29}$

Dalam Al-Quran, Allah Swt. Tidak dinamakan ,, arif, tetapi „, alim yang memiliki kata kerja (Dia mengetahui). Biasanya Al- Qur" an menggunakan kata ini untuk Allah dalam hal-hal yang diketahuinya, walaupun gaib tersembunyi atau dirahasiakan. Perhatikan objek-objek pengetahuan berikut ini yang dinisbatkan kepada Allah: ya'lamu ma yusirrun (Allah mengetahui apa yang mereka rahasiakan), ya 'lamu ma fil arham(Allah mengetahui sesuatu yang berada di dalam rahim, ma tahmilu kullu untsa(apa yang dikandung oleh setiap betina/perempuan), ma fi anfusikum (yang ada dalam dirimu), ma fis samawat wa ma filardhi (yang ada dilangit dan dibumi), kha'inatal- a'yun wa ma tukhfi al-shudur (kedipan mata dan yang disembunyikan dalam dada). Demikian juga kata ,ilm yang disandarkan kepada manusia. Semuanya mengandung makna kejelasan. $^{30}$

5. Pengertian Amal

Amal mempunyai pengertian yang luas baik yang berhubungan dengan Allah Swt, sesama manusia, diri sendiri dan alam semesta. Sehingga bentuk amal dapat berupa pikiran, tenaga dan pemberian harta

\footnotetext{
${ }^{29}$ Nurcholis Madjid, Islam Doktrin dan Peradaban: Sebuah Telaah Kritis tentang Masalah Keimanan, Kemanusiaan, dan Kemoderenan, cet. Ii. Jakarta: Paramadina, 1992, hlm. 9495

${ }^{30}$ M. Qurais Shihab, Wawasan Al-Qur'an: Tafsir Maudhu'i atas Pelbagai Persoalan Umat, cet. iv. Bandung, Mizan. 1996.Suyuthi, Jalaluddin. Lubāb al-Nuqūl fì Asbāb alNuzūl.Libanon:Daral-Kutubal- „Ilmiyyah, 2012, hlm. 445-446
} 
benda. Adapula yang berupa ucapan dan tingkah laku yang baik dalam kehidupan dan pergaulan sehari-hari. ${ }^{31}$

Menurut Mohammad Iqbal bahwa amal dalam Al-Qur'an lebih mengutamakan perbuatan ketimbang ide karena perbuatan baik ( amal soleh) mempunyai kedudukan yang tinggi. Hal ini terlihat dari Qs. Taahaa ayat 112:

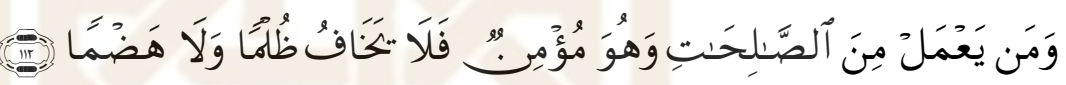

Artinya: "Dan barangsiapa mengerjakan amal-amal yang saleh dan ia dalam keadaan beriman, Maka ia tidak khawatir akan perlakuan yang tidak adil (terhadapnya) dan tidak (pula) akan pengurangan haknya".

Seorang yang melakukan perbuatan yang baik yaitu perbuatan yang berguna bagi manusia dan dirinya sendiri, dapat melindunginya dari perbuatan salah. Demikian pula amal yang baik bisa menimbulkan hak misalnya ganjaran, keberhasilan atau manfaat. ${ }^{32}$

Menurut penulis hubungan komunikasi edukatif dalam pemaduan iman, ilmu dan amal adalah sangat pentik dimana ada komunikasi yang baik akan bisa menyampaikan pembelajaran iman kepda peserta didik dan komunikasi yang baik bisa menyampaikan ilmu kepada siswa dengan baik dan komunikasi yang baik bisa mengamalkan dengann baik, intinya dari hubungan komunikasi edukatif pemaduan iman, ilmu dan amal adalah untuk menyampaikan hubungan komunikasi di dalam pembelajaran, di

\footnotetext{
${ }^{31}$ Fachruddin H S, Ensklopedia al-Qur " an, Jilid.1(Jakarta: Rineka Cipta, 1992),hlm. 95

${ }^{32}$ Karwadi, Al-Qur'an dan Pembelajarannya, (Yogyakarta: Pokja Akademik UIN Sunan Kalijaga, 2006), hlm. 46-47
} 
kelas ataupun di luar kelas sehingga hubungan komunikasi edukatif dalam pemaduan iman, ilmu dan amal bisa berjalan dengan baik.

\section{G. Metode Penelitian}

Metode penelitian adalah uraian singkat mengenai jenis penelitian, pendekatan yang digunakan, sumber data, metode penentuan subjek, metode pengumpulan data dan metode analisis data. Adapun dalam metode penelitian ini akan menjelaskan hal-hal yang berkaitan dengan:

\section{Jenis Penelitian}

Jenis penelitian ini adalah penelitian lapangan (field research) yang bersifat kualitatif, yakni penelitian yang berlandaskan pada filsafat postpositivisme, digunakan untuk meneliti pada kondisi obyek yang alamiah (sebagai lawannya adalah eksperimen) dimana peneliti adalah sebagai insrumen kunci, pengambilan sampel sumber data bersifat induktif/kualitatif dan hasil penelitian lebih menekankan makna dari pada generalisasi. ${ }^{33}$ Penelitian kualitatif lebih diarahkan untuk memahami fenomena-fenomena sosial dan perspektif partisipan.Ini diperoleh melalui pengamatan dalam kehidupan orang-orang yang menjadi partisipan. ${ }^{34}$

\section{Pendekatan Penelitian}

Penelitian ini membahas tentang implementasi komunikasi edukatif dalam pemaduan iman, ilmu dan amal, maka penelitian ini menggunakan pendekatan sosiologis. Selain itu penelitian ini juga

\footnotetext{
${ }^{33}$ Sugiyono, Metode Penelitian Pendidikan, Pendekatan Kuantitatif, Kualitatif Dan $R$ $\& D$, (Bandung: ALVABETA, 2009), hlm.15.

${ }^{34}$ Nana Syaodih, Sukmadinata, Metode Penelitian Pendidikan, (Bandung: PT. Remaja Rosdakarya, 2008), hlm.5.
} 
menggunakan pendekatan objektif, yaitu pendekatan yang menggali informasi seobjektif mungkin mengenai komunikasi edukatif dalam pemaduan iman, ilmu dan amal. Kedua pendekatan ini digunakan terkait dengan fokus penelitian yang ingin mengetahui implementasi komunikasi edukatif dalam pemaduan iman, ilmu dan amal studi pembelajaran PAI di SMA IT Abu Bakar Yogyakarta.

\section{Subjek Penelitian}

Subjek penelitian adalah subjek yang dituju untuk diteliti oleh peneliti. Subjek dalam penelitian ini adalah orang-orang yang mengetahui, berkaitan dan menjadi pelaku dalam proses implementasi komunikasi edukatif dalam pemaduan iman, ilmu dan amal yang diharapkan dapat memberikan informasi. Subjek dalam penelitian ini antara lain:

a. Peserta didik SMA IT Abu Bakar Yogyakarta, khususnya kelas X1 Mia ${ }^{1}$ yang berjumlah 27 siswa, sebagai sumber informasi utama untuk memperoleh informasi tentang implementasi komunikasi edukatif dalam pemaduan iman, ilmu dan amal studi pembelajaran PAI di SMA IT Abu Bakar Yogyakarta.

b. Guru Pendidikan Agama Islam yang berjumlah 3 orang yang mengajar di SMA IT Abu Bakar Yogyakarta, untuk mengetahui hal-hal yang berkaitan dengan implementasi komunikasi edukatif dalam pemaduan iman, ilmu dan amal studi pembelajaran PAI di SMA IT Abu Bakar Yogyakarta. 


\section{Metode Pengumpulan Data}

Dalam mengumpulkan data yang berkaitan dengan judul penelitian ini, maka penulis menggunakan metode observasi, wawancara, dokumentasi.

a. Metode Observasi

Metode observasi adalah metode pengumpulan data dengan pengamatan secara langsung maupun secara tidak langsung. Metode pengamatan yang digunakan secara langsung (direct observation), yaitu pengamatan yang dilakukan tanpa perantara terhadap obyek yang diteliti. Metode ini digunakan untuk mengamati tentang implementasi komunikasi edukatif dalam pemaduan iman, ilmu dan amal studi pembelajaran PAI yang berlangsung di dalam kelas, sekitar kelas dan berbagai metode dan sarana yang menunjang pembelajaran tersebut.

b. Metode Wawancara (Interview)

Metode interview atau wawancara dilakukan secara lisan dalam pertemuan atau tatap muka secara individual atau kelompok.Wawancara merupakan pertemuan dua orang untuk bertukar informasi dan ide melalui tanya jawab, sehingga dapat dikontruksikan makna dalam suatu topik tertentu. ${ }^{35}$ Jenis wawancara bebas terpimpin. Pewawancara hanya memuat pokokpokok masalah yang akan diteliti. Pewawancara harus pandai

\footnotetext{
${ }^{35}$ Sugiyono, Metode Penelitian Pendidikan....,hlm. 317.
} 
mengarahkaninforman yang akan diwawancarai ketika wawancara. Pedoman interview berfungsi sebagai pengendali supaya proses wawancara tidak kehilangan arah.

Metode ini digunakan untuk mengetahui implementasi komunikasi edukatif dalam pemaduan iman, ilmu dan amal studi pembelajaran PAI, implementasinya dan hasil dari Implementasi komunikasi edukatif dalam pemaduan iman, ilmu dan amal studi pembelajaran PAI di SMA IT Abu Bakar Yogyakarta.

c. Metode Dokumentasi

Metode dokumentasi merupakan metode penelitian untuk memperoleh data dan dulumen berupa catatan laporan kerja.notulen rapat, catatan kasus, transkip nilai, foto, agenda, sejarah dan lain sebagainya. ${ }^{36}$ Metode ini digunakan untuk memperoleh data yang diperlukan antara lain letak geografis, sejarah berdirinya, visi dan misi, sarana prasarana, keadaan dan jumlah siswa, jadwal pelajaran, fungsi masjid dalam pencapaian mutu pelajaran.

\section{d. Triangulasi}

Triangulasi diartikan sebagi teknik pengumpulan data yang bersifat menggabungkan dari berbagai teknik pengumpulan data dan sumber data yang sudah ada. ${ }^{37}$ Singkatnya tri angulasi merupakan kroscek terhadap kebenaran data. Metode pengumpulan data

\footnotetext{
${ }^{36}$ Suharsimi Arikunto, Prosedur Penelitian Suatu Pendekatan Praktek (Jakarta: Rineka Cipta, 1992), hlm.200.

${ }^{37}$ Sugiyono, Metode Penelitian Pendidikan., hlm. 330.
} 
dengan triangulasi maka sebenarnya peneliti mengumpulkan data yang sekaligus menguji kredibilitas data dengan berbagai teknik pengumpulan data dan berbagai sumber data. Triangulasi dapat meningkatkan pemahaman peneliti terhadap apa yang telah ditemukan.

5. Teknik Analisis Data

Setelah data terkumpul, selanjutnya data tersebut diklarifikasikan dan dianalisis dengan teknik deskriptif analitis. $^{38}$ Penulis menggunakan teknik penyeleksian data, melakukan penyederhanaan data kedalam bentuk paparan untuk memudahkan dibaca dan dipahami, kemudian diinterprestasikan dengan jelas untuk menjawab permasalahan yang diajukan, data dipaparkan sedetail mungkin dengan uraian-uraian serta analisis kualitatif.

Setelah data terhimpun, maka diklarifikasikan sesuai dengan masdalah yang di bahas dan di analisis isinya, dibandingkan data yang satu dengan yang lainnya, kemudian di interprestasikan dan khirnya di beri kesimpulan.

${ }^{38}$ Deskripsi berarti menggambarkan fenomena-fenomena yang ada, baik fenomena yang bersifat alamiah, maupun rekayasa manusia guna memahami bentuk, aktivitas, karakteristik, perubahan, hubungan, kesamaan dan perbedaannya dengan fenomena lain. Baca Nana Syaodih Sukmadinata. Metode Penelitian Pendidikan, (Bandung: Remaja Rosdakarya, 2005), hlm.72. sedangkan analitik adalah jalan atau cara yang dipakai untuk mendapatkan ilmu pengetahuan ilmiah dengan jalan memilih-milih antara suatu pengertian dengan pengertian yang lain sekedar untuk memperoleh kejelasan mengenai objek tersebut. Baca Sudarto, Metode Penelitian Filsafat, (Jakarta: Raja Grafindo Persada, 1996), hlm.48. 
Data yang diperoleh dalam penelitian ini berupa hasil observasi kegiatan peserta didik selama di sekolah, data dari hasil wawancara dengan pihak-pihak terkait serta data dari studi dokumen terkait. Kemudian data-data yang diperoleh dianalisis dalam beberapa tahap yaitu:

a. Tabulasi dan Klarifikasi Data

Pada tahap ini peneliti mengumpulkan data-data yang mendukung implementasi komunikasi edukatif dalam pemaduan iman, ilmu dan amal studi pembelajaran PAI di SMA IT Abu Bakar Yogyakarta, melalui observasi, wawancara dan studi dokumen terkait.

b. Reduksi Data

Pada tahap reduksi ini data difokuskan pada hal-hal yang penting serta menghapus data-data yang tidak terpola dengan cara cek silang antara hasil observasi dengan dokumentasi terkait.

c. Interpretasi Data

Setelah didapatkan data yang spesifik, pada tahap ini peneliti menginterpretasikan data atau mendeskripsikan data pada bagian hasil penelitian dan pembahasan yang sejelas-jelasnya. 
d. Kesimpulan Data

Pada tahap terakhir ini peneliti menarik kesimpulan dari data yang telah dianalisis dan dideskripsikan, sehingga akan didapat kesimpulan akhir tentang gambaran implementasi komunikasi edukatif dalam pemaduan iman, ilmu dan amal studi pembelajaran PAI di SMA IT Abu Bakar Yogyakarta. Teknik penyimpulan data dengan metode induktif yaitu mencari data sebanyak-banyaknya lalu disimpulkan (umum-khusus).

\section{H. Sistematika Pembahasan}

Agar hasil pembuatan tesis ini mudah dipahami, maka penulis menuturkan sistematika penulisan tersebut untuk mengklarifikasikan persoalan-persoalan yang ada. Penelitian ini terdiri dari 5 (lima) bab yang terbagi atas sub-sub bab yang ada di dalamnya. Adapun secara lebih rinci sistematika pembahasan tesis ini sebagai berikut:

Bab Pertama, pendahuluan, bab ini berisi latar belakang masalah, rumusan masalah, tujuan dan kegunaan penelitian, kajian pustaka, kerangka teoritik, metode penelitian dan sisematika pembahasan.

Bab Kedua, membahas beberapa kajian teori berisi tentang implementasi komunikasi edukatif dan pemaduan iman, ilmu dan amal.

Bab Ketiga, berisi tentang deskripsi tentang sekolah SMA IT Abu Bakar Yogyakarta yang menjelaskan letak geografis dan keadaan sekolah, sejarah berdirinya dan proses perkembangannya, dasar dan tujuan 
pendidikannya, visi misi sekolah, struktur organisasi, keadaan guru, karyawan dan siswa serta keadaan sarana dan prasarana penunjang pengembangan pendidikan.

Bab Keempat, berisi tentang analisis konsep dan implementasi komunikasi edukatif dalam pemaduan iman, ilmu dan amal studi pembelajaran PAI di SMA IT Abu Bakar Yogyakarta, implementasi komunikasi edukatif dalam pemaduan iman, ilmu dan amal studi pembelajaran PAI di SMA IT Abu Bakar Yogyakarta, kontribusi lembaga pendidik dalam implementasi komunikasi edukatif dalam pemaduan iman, ilmu dan amal studi pembelajaran PAI di SMA IT Abu Bakar Yogyakarta.

Bab Kelima, merupakan bab terakhir yang sekaligus menjadi penutup dari tesis ini. Adapun isinya terdiri dari kesimpulan dari hasil penelitian, kritik dan saran yang berhubungan dengan penelitian. Sub terakhir pada bagian utama yaitu daftar pustaka. Sebagai sumber pustaka penulis mengembangkan tesis.

Bagian akhir, dalam penulisan tesis ini terdiri dari lampiran-lampiran, dan daftar riwayat hidup penulis. 


\section{BAB V}

\section{PENUTUP}

\section{A. KESIMPULAN}

Berdasarkan penelitian yang dilaksanakan di sekolah SMA IT Abu Bakar Yogyakarta dengan menggunakan metode wawancara, observasi, dan dokumentasi, peneliti memperoleh hasil penelitian yang dapat menjawab rumusan masalah yang telah disusun dan dapat menyimpulkan hasil analisis dan pembahasan sebagai berikut:

1. Konsep dan implementasi komunikasi edukatif dalam pemaduan iman, ilmu dan amal. Studi pembelajaran PAI di SMA IT Abu Bakar Yogyakarta, jadi seorang guru harus menyiapkan bahan ajar dan seorang guru harus mampu menjelaskan dan bisa menguasai materi yang di ajarkan di dalam kelas, dan seorang guru harus mampu memberikan contoh dalam kehidupan sehari-hari supanya siswa mudah memahami isi materi yang di ajarkannya dan konsep dalam pembelajaran PAI mengacu pada kurikulum JSIT dan penggabungan dinas contohnya dengan memadukan iman, ilmu dan amal dalam kehidupan sehari-hari. Memberikan pendidikan iman, ilmu dan amal dari dasar apa itu iman, ilmu dan amal dan mengaplikasikan dalam masyarakat dan kehidupan sehari-hari dan di jelaskan iman itu pokok ya, ilmu itu caranya dan amal itu pengaplikasiannya, dan memberikan kajian dalam dauroh kajian tematik yang isi temanya tentang iman, ilmu dan amal, seperti shalat duha, literasi, setiap kegiatan harus di awali dengan bismilah dan do'a 
dan mengakhiri kegiatan dengan doa dan salam dan harus disiplin, memberikan pembelajaran tentang rukun iman, ilmu dan amal secara keseluruhan dan mengaplikasikan dalam kehidupan sehari-hari, sejarah nabi sedangkan iman kepada rasul dan hari akhir dengan pembelajaran ini anak paham apa itu iman, ilmu dan amal. Anak terbiasa shalat berjama'ah, ada kegiatan mentoring yang memberikan pembelajaran agama dan bisa mengetahui kopetensi yang dimiliki siswa, anak menjadi lebih kuat takwaya, kuat aqidahnya, mengetahui nilai-nilai islam dan ideologi yang lain seperti punya wawasan ma'rifat dan mempunyai adap kepada guru, teman, kedua orangtua. Keterpaduan islamik intergiti dan semua mata pelajaran dalam mengajarkan mengkaitkan dengan PAI, contohnya dalam ilmu biologi.

2. Implementasi komunikasi edukatif dalam pemaduan iman, ilmu dan amal. Studi pembelajaran PAI di SMA IT Abu Bakar Yogyakarta, implementasinya pukul 7:30 semua siswa sudah di dalam kelas dan membaca do'a dan tadarus al-Qur'an, setiap hari jumat bagi yang putra wajib shalat jum'at, puasa senin kamis, makan bersama, mengadakan peringatan hari besar seperti pesantren kilat di bulan romadhon, bakti amal sosial dan di SMA IT Abu Bakar Yogyakarta tidak mengenal hari setiap hari ada program Islami, seni keislaman kaligrafi, tilawah, hadroh, nasid, dan ada mentoring agama dan ada Boarding Scool, Full Day, Ekstrakulikuler, olahraga, robotik, jurnal, pramuka (kepanduan), mentoring membeking iman, ilmu dan amal. pengaruhnya dari berbagai 
sisih dari segi shalat berjama'ah, lembar kontrol dan akhlakulkarimah, siswa melihat sosok guru yang di sukai bagaimana kedekatan seorang guru kepada siswanya komunikasi edukatifnya dan luar biasa jadi manusia yang hebat, jadi dokter yang mempunyai keimanan, ilmu dan amal yang bisa membantu pasyennya. metode yang digunakan banyak membangun pemahaman, diskusi, ceramah, proyek, riset, direk method, pembiasaan, ceramah, vidio, praktek, seperti ilmu ceramah, iman meto teladan dan amal praktik langsung, metode pemahaman, pembiasaan, pemantauan dengan adanya mentor, metode kegiatan seperti di pondok dan kemah nuansa IT.

3. Kontribusi lembaga pendidik dalam implementasi komunikasi edukatif dalam pemaduan iman, ilmu dan amal. Studi pembelajaran PAI di SMA IT Abu Bakar Yogyakarta, kontribusi konsepya jelas KYM yaitu konsursium yayasan mulia mengawal dan mengelola yayasan dari konsep pembelajaran, Islam jadi ruh utama di SMA IT Abu Bakar Yogyakarta jadi semua guru seperti guru PAI dan dari SD, SMP, SMA, yayasan bagaimana mengelola dari segi manajemen, fasilitas, litbang semuanya yang mengurusi yayasan sangat membantu dan kegiatan pembelajaran.

\section{B. Saran-Saran}

Berdasarkan hasil penelitian yang telah dilaksanakan di sekolah SMA IT Abu Bakar Yogyakarta, ada beberapa saran dari peneliti terkait tentang implementasi komunikasi edukatif dalam pemaduan iman, ilmu dan amal. Studi pembelajaran PAI di SMA IT Abu Bakar Yogyakarta, antara lain: 
1. Ustadz/Ustadzah sebaiknya selalu memberikan teladan yang baik kepada peserta didik mulai dari hal yang terkecil dan sederhana.

2. Ustdaz/Ustadzah sebaiknya mengetahui kegiatan-kegiatan peserta didik di sekolah sehingga dapat memberikan arahan dan bimbingan dalam pendidikan iman, ilmu dan amal yang sejalan dengan kegiatan peserta didik di sekolah.

3. Para peserta didik hendaknya selalu memperbaiki niat untuk belajar dan menimba ilmu dengan sungguh-sungguh serta mematuhi segala peraturan yang tertuang dalam buku panduan tata tertib sekolah.

4. Para orangtua atau wali peserta didik sebaiknya selalu memberi motivasi dan nasehat kepada peserta didik agar mereka bersungguh-sunggu dalam menjalani pendidikan di sekolah SMA IT Abu Bakar Yogyakarta.

\section{Penutup}

Alhamdulilahi rabbil'alamin. Segala puji bagi Allah Swt. Atas keagungan dan kemurahan-Nya dalam memberikan petunjuk, jalan, kemudahan, kesabaran, serta semangat kepada penulis dalam menyelesaikan tesis ini. Penulis telah berusaha dengan segenap kemampuan yang dimiliki untuk menyusun tesis ini semaksimal mungkin. Namun ibarat peribahasa "tiada gading yang tak retak", sebagai manusia biasa yang masih dalam proses belajar, tentu saja dalam penyusunan tesis ini masih banyak kekurangan di dalamnya.

Oleh karena itu, penulis sangat mengharapkan kritik dan saran yang membangun dari para pembaca demi perbaikan dari penulis dan penelitian selanjunya. Terlepas dari kekurangan dan keterbatasan yang ada, penulis berharap 
penelitian tesis ini dapat bermanfaat bagi pembaca pada umumnya, dan pemerhati pendidikan Islam pada khususnya. Semoga Allah Swt. Memberi limpahan dan rahmah kepada kita semua. Amiin ya rabbal'alamin.

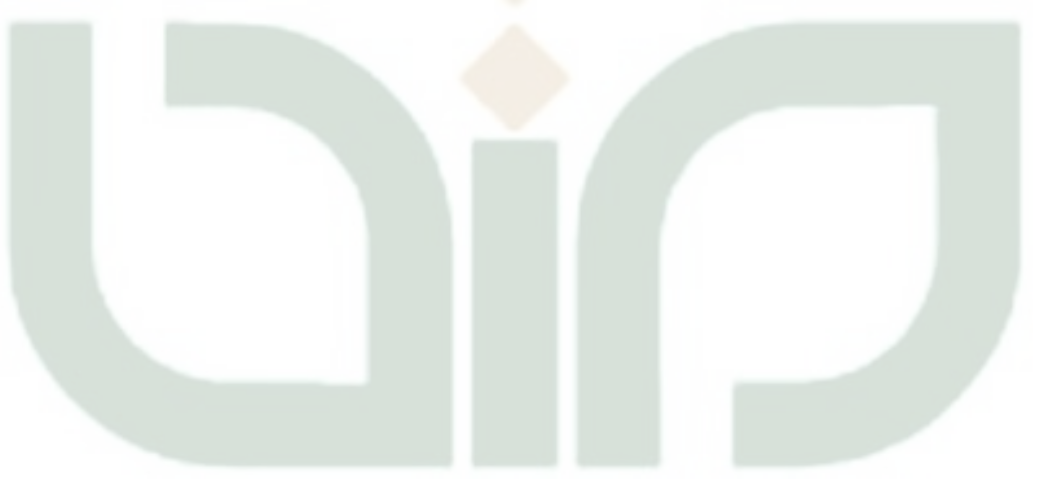




\section{DAFTARPUSTAKA}

Buku:

Aditya Nagara, Kamus Praktis Bahasa Indonesia, Surabaya: PT. Bintang Usaha Jaya, 2002.

Anwar Arifin, Ilmu Komunikasi, Jakarta: PT Raja Grafindo Persada, 1995.

Brantas, Dasar-dasar Manajemen, Bandung:Alfabeta, 2009.

Citobroto, Komunikasi (Komunikasi \& Hubungan Masyarakat), Jakarta: PT Bumi Aksara, 1982.

Fachruddin H S, Ensklopedia al-Qur" an, Jilid.1 Jakarta: Rineka Cipta, 1992.

Hasibuan J.J dan Moedjiono, Proses Belajar Mengajar, Bandung: PT Remaja Rosdakarya, 2006.

Hafled Cangara, Pengantar ilmu Komunikasi, Jakarta: PT Raja Grafindo, 2011.

Herlina, Komunikasi Verbal, Makalah mata Kuliyah Ilmu Pernyataan Jurusan Psikologi, Bandung: Universitas Pendidikan Indonesia (UPI), 2013.

Iriantara, Komunikasi Antar Pribadi, (Tangerang: Universitas Terbuka, 2014.

Jaluddin, Teologi Pendidikan, Jakarta, Raja Grafindo Persada, 2003.

Kurniawati, Komunikasi Antar Pribadi: Konsep dan Teori Dasar, Yogyakarta: Graha Ilmu, 2014.

Karwadi, Al-Qur'an dan Pembelajarannya, Yogyakarta: Pokja Akademik UIN Sunan Kalijaga, 2006.

Kenneth N. Wexley \& Gary A. Yuki, di terjemahkan oleh Muh Shobaruddin, Perilaku Organisasi dan Psikologi Personalia, Jakarta: PT Rineka Cipta, 2003.

Moh. Uzer Usman, Menjadi Guru Profesional, Bandung: PT Remaja Rosdakarya, 2006.

Mahmud Arif, Umi Baroroh, Karwadi, Al-Qur'an Dan Pembelajarannya, Pokja Akademik UIN Sunan Kalijaga Yogyakarta, 2006. 
Muh Nurul Huda, Komunikasi Pendidikan Teori Dan Aplikasi Komunikasi Dalam Pembelajaran, Tulung Agung: STAIN Press, 2013.

Mulyana, Ilmu Komunikasi Suatu Pengantar, (Bandung:PT Remaja Rosdakarya, 2012.

M. Kasir Ibrahim, Kamus Arab Indonesia; Indonesia Arab, (Surabaya : PT. Apollo Lestari, 2008.

M. Qurais Shihab, Wawasan Al-Qur'an: Tafsir Maudhu'i atas Pelbagai Persoalan Umat, cet. iv. Bandung, Mizan. 1996.Suyuthi, Jalaluddin. Lubāb al-Nuqūl fì Asbāb al- Nuzūl.Libanon:Daral-Kutubal- „Ilmiyyah, 2012.

Nana Syaodih, Sukmadinata, Metode Penelitian Pendidikan, Bandung: PT. Remaja Rosdakarya, 2008.

Nurcholis Madjid, Islam Doktrin dan Peradaban: Sebuah Telaah Kritis tentang Masalah Keimanan, Kemanusiaan, dan Kemoderenan, cet. Ii. Jakarta: Paramadina, 1992.

Ngainun Naim, Dasar-dasar Komunikasi Pendidikan, Yogyakarta: Ar- Ruzz Media, 2011.

Onong Uchjana Effendi, Dinamika Komunikasi, Bandung:PT Remaja Rosdakarya, 2009.

Pawit M. Yusuf, Komunikasi Intruksional, Teori dan Praktek, Jakarta: Bumi Aksara, 2010.

Winarno Surakhmad, Komunikasi Intruksional, Teori dan Praktek, Jakarta: Bumi Aksara, 1994.

Suryosubroto B, Proses Belajar Mengajar Di Sekolah, Jakarta: PT Rineka Cipta, 2002.

Suranto AW, Komunikasi Perkantoran (Prinsip Komunikasi Untuk Meningkatkan Kinerja Karyawan), Yogyakarta: Media Wacana, 2005.

Suhartono, Psikologi Pendidikan, Yogyakarta: UNY Press, 2002.

Suharsimi Arikunto, Prosedur Penelitian Suatu Pendekatan Praktek, Jakarta: Rineka Cipta, 1992.

Sugiyono, Metode Penelitian Pendidikan, Pendekatan Kuantitatif, Kualitatif Dan $R \& D$, Bandung: ALVABETA, 2009. 
Syaiful Bahri Djamarah, Guru dan Anak Didik Dalam Interaksi Edukatif, Jakarta: PT Rineka Cipta, 2005.

Sardiman A.M, Interaksi \& Motifasi Belajar Mengajar, Jakarta: PT Raja Grafindo Persada, 2012.

Suhaenah Suparno A, Membangun Kopetensi Belajar, Jakarta: Dirjendikti, 2001.

Syahminan Zaini, Tinjauan Analisis Tentang Iman, Islam dan Amal, (Malang: KalamMulia, 2006, Cet ke-III, 2006.

Titiek Triwidodo \& Djoko Kristanto, Pengembangan Kpribadian Sekretaris, Jakarta: PT Grasindo, 2004.

Widjaja H.A.W, Komunikasi (Komunikasi \& Hubungan Masyarakat), Jakarta: PT Bumi Aksara, 2010.

Zainuddin Ali, Pendidikan Agama Islam, Jakarta: PT. Bumi Aksara, 2011, Cet keIV.

Zuhdiyah, Psikologi Agama, (Yogyakarta : Pustaka Felicha, 2012.

Jurnal:

Ety Nur Inah, Peran Komunikasi Dalam Interaksi Guru Dan Siswa, Jutrnal AlTa'dib Vol 8 No.2, Juli-Desember, 2015.

M. Saekan Muchith, Membangun Komunikasi Edukatif, Jurnal At-Tarbiyah, Jurnal Komunikasi Penyiaran Islam vol 3, No.1 Juni 2015.

Nurdin Manyak, Posisi Pendidikan Islam Dalam Mengembangkan Ilmu, Iman Dan Amal Shaleh, Jurnal Mudarrisuna, Vol 3, Nomor 2 Juli-Desember 2013.

Ribhan," Hubungan Karakteristik individu Dengan Kinerja Karyawan Melalui KomitmenOrganisasi sebagai variabel Mediasi (Studi Kasus oada PT Chandra Superstore Tanjung Karang Bandar Lampung), Jurnal Bisnis Dan Manajemen, Vol.4 No.2,2008.

Tri Suzanti, Interaksi Edukatif Dalam Proses Belajar Mengajar Sosiologi Di Sma Negeri 1 Bungoro Kabupaten Pangkep Jurnal Sosialisasi Vol 4 Edisi 1, Maret 2017.

Zuradah Binti Othman, Dr. Hasan Alzan Binti Ali, Pendidikan Integratif Dalam Islam: Kesepaduan Iman,Ilmu Dan Amal, Jurnal Al Muqaddimah Bill 2 (2) 2004. 
Dokumentasi SMA IT Abu Bakar Yogyakarta

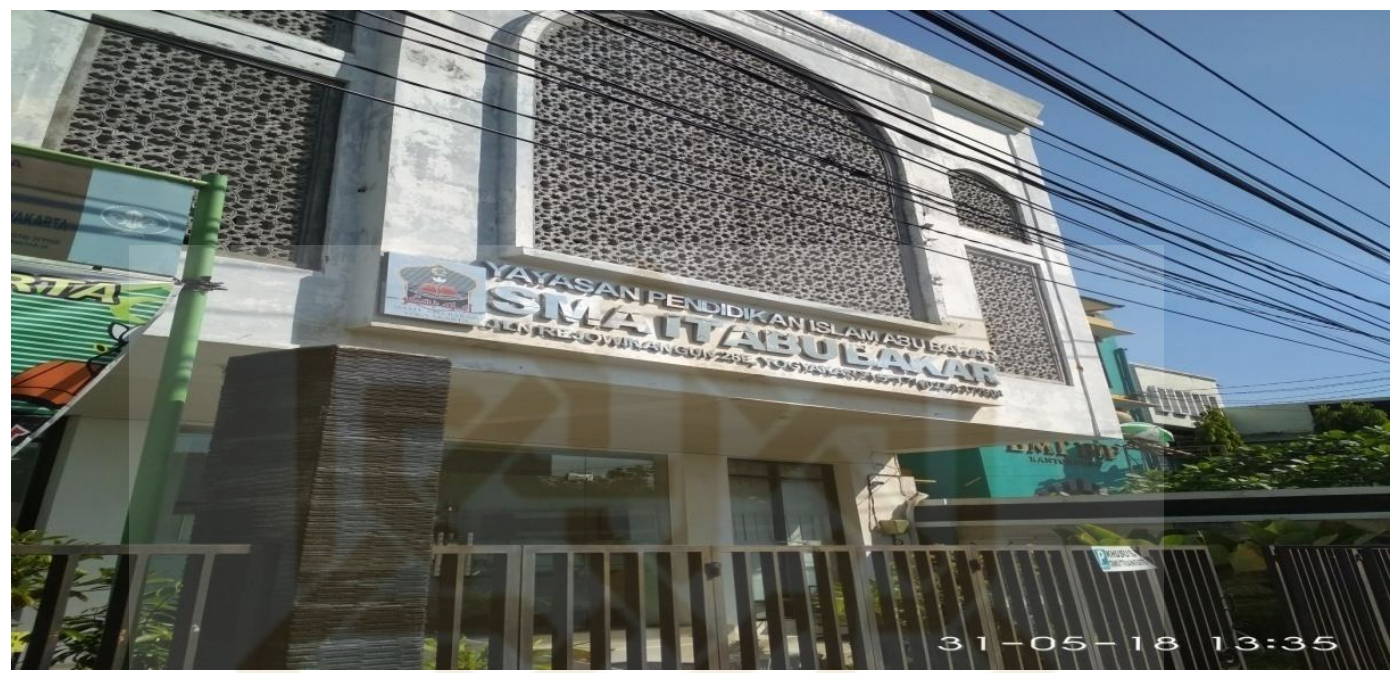

Gambar 01. Tampak Depan SMA IT Abu Bakar Yogyakarta

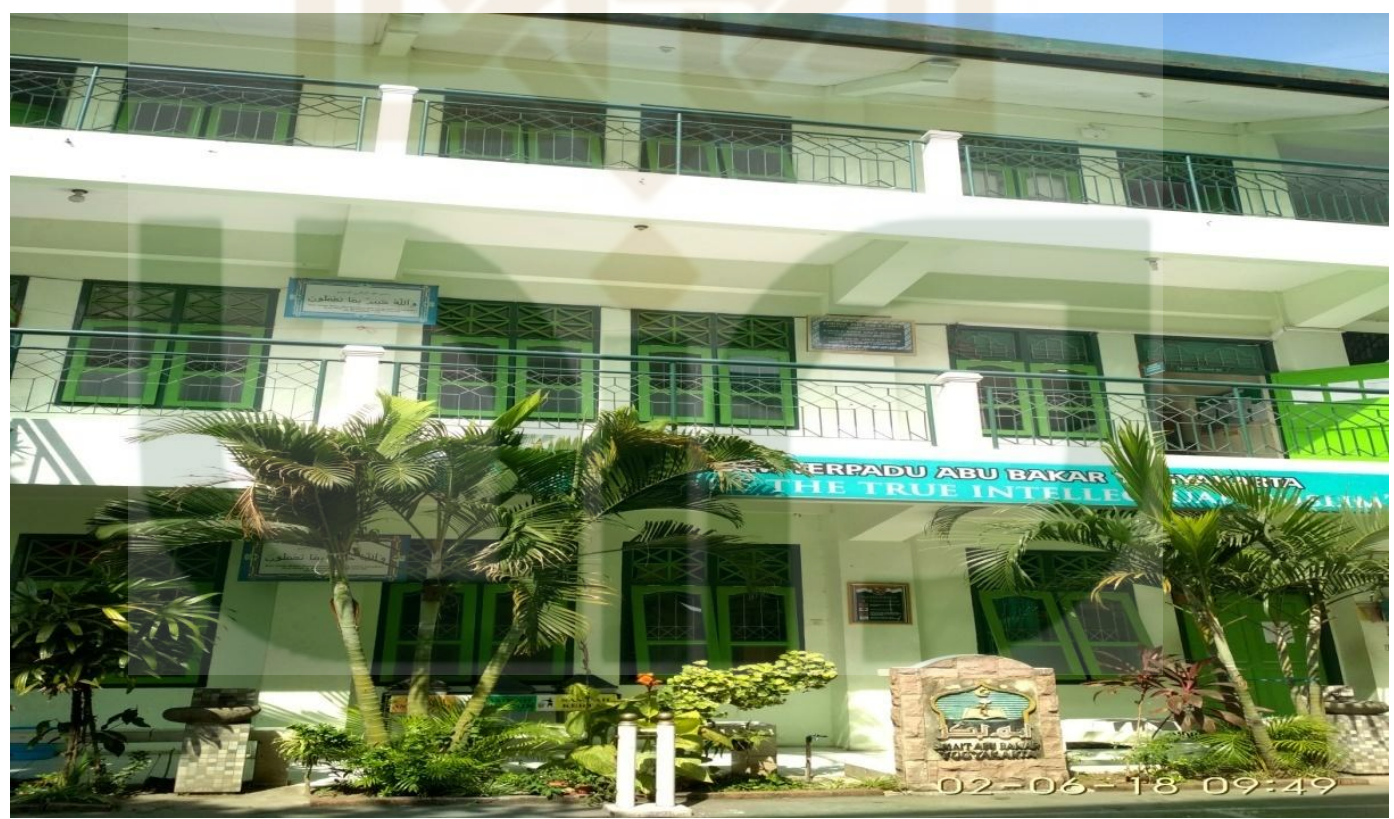

Gambar.02

Halaman depan SMA IT Abu Bakar Yogyakarta 


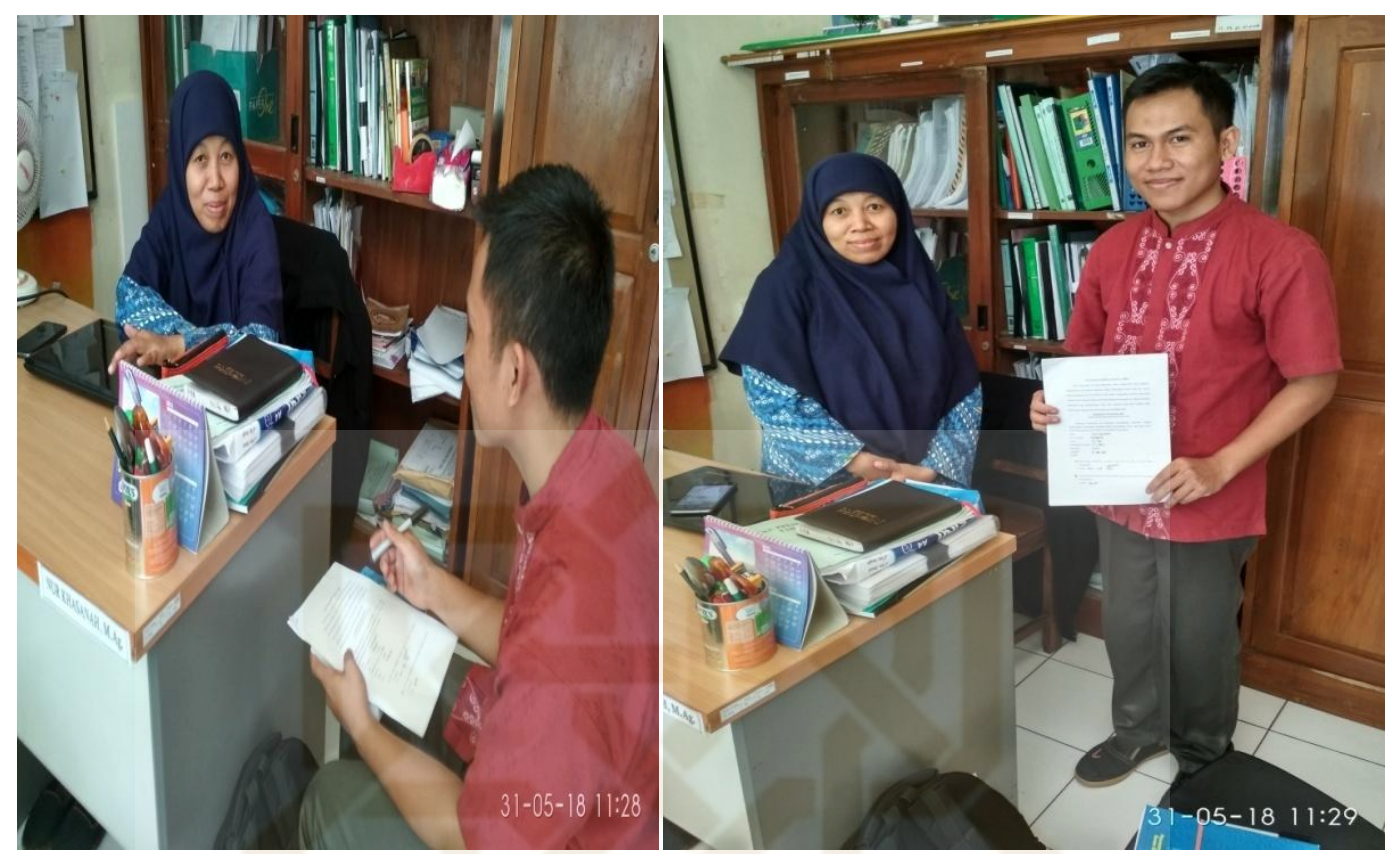

Gambar.03

Wawancara Ibu Nurhasanah. M.Ag, di Ruang Kurikulum SMA IT Abu Bakar Yogyakarta

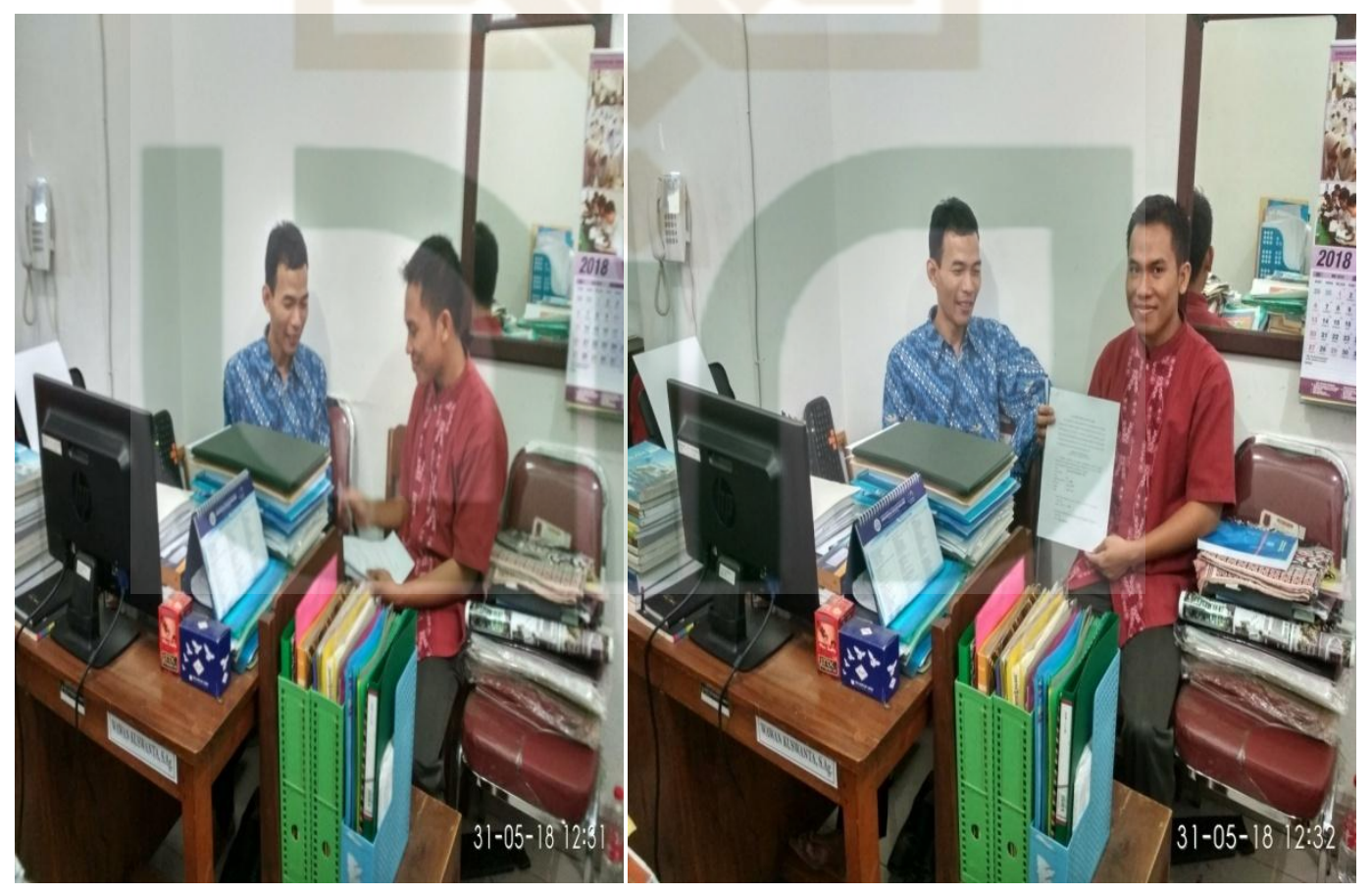

Gambar.04

Wawancara Bapak Wawan Kuswanto. S.Ag, di Ruang Guru SMA IT Abu Bakar Yogyakarta. 


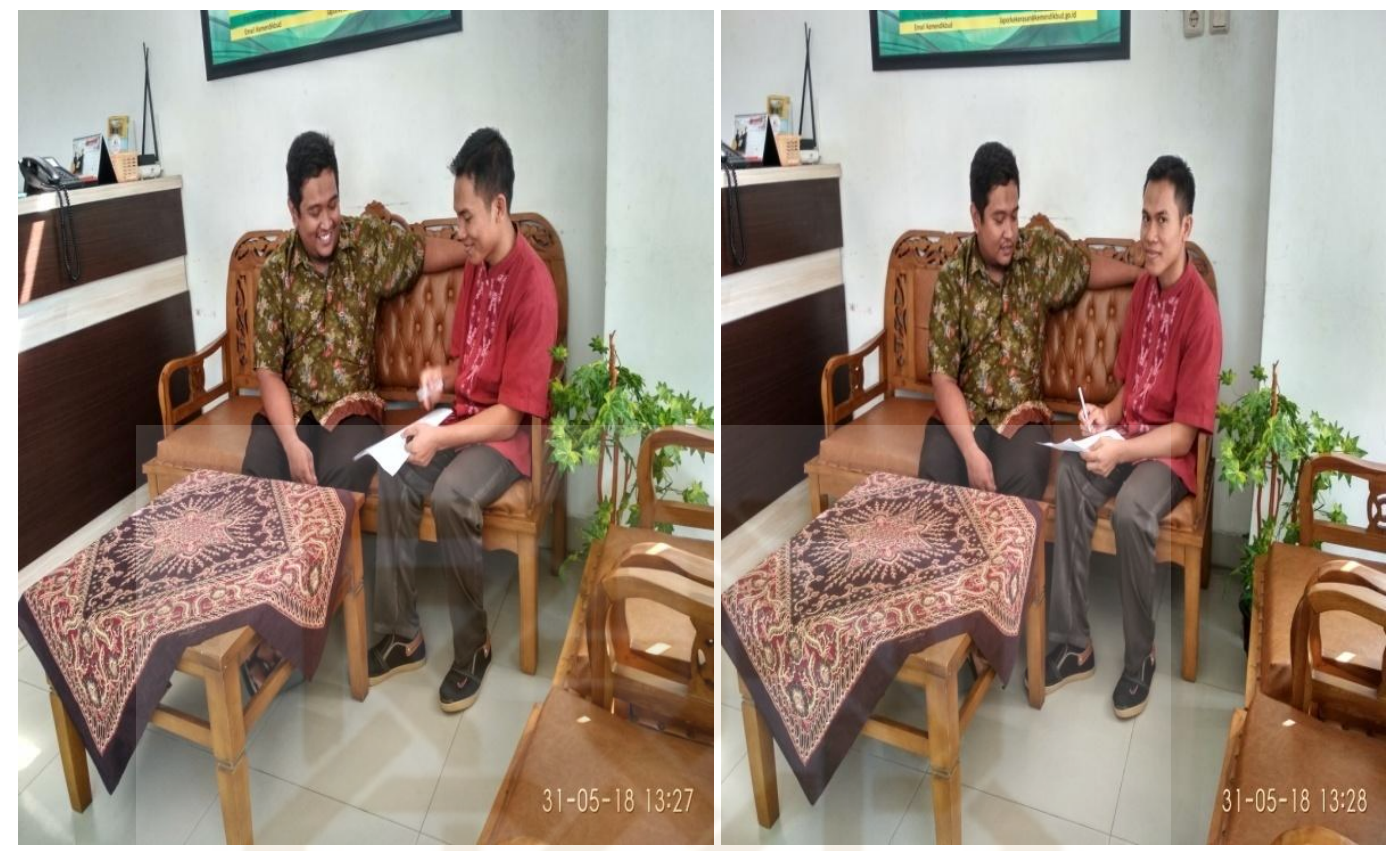

Gambar.05

Wawancara Arif Utomo. S.Ag, di Ruang Tamu SMA IT Abu Bakar Yogyakarta.
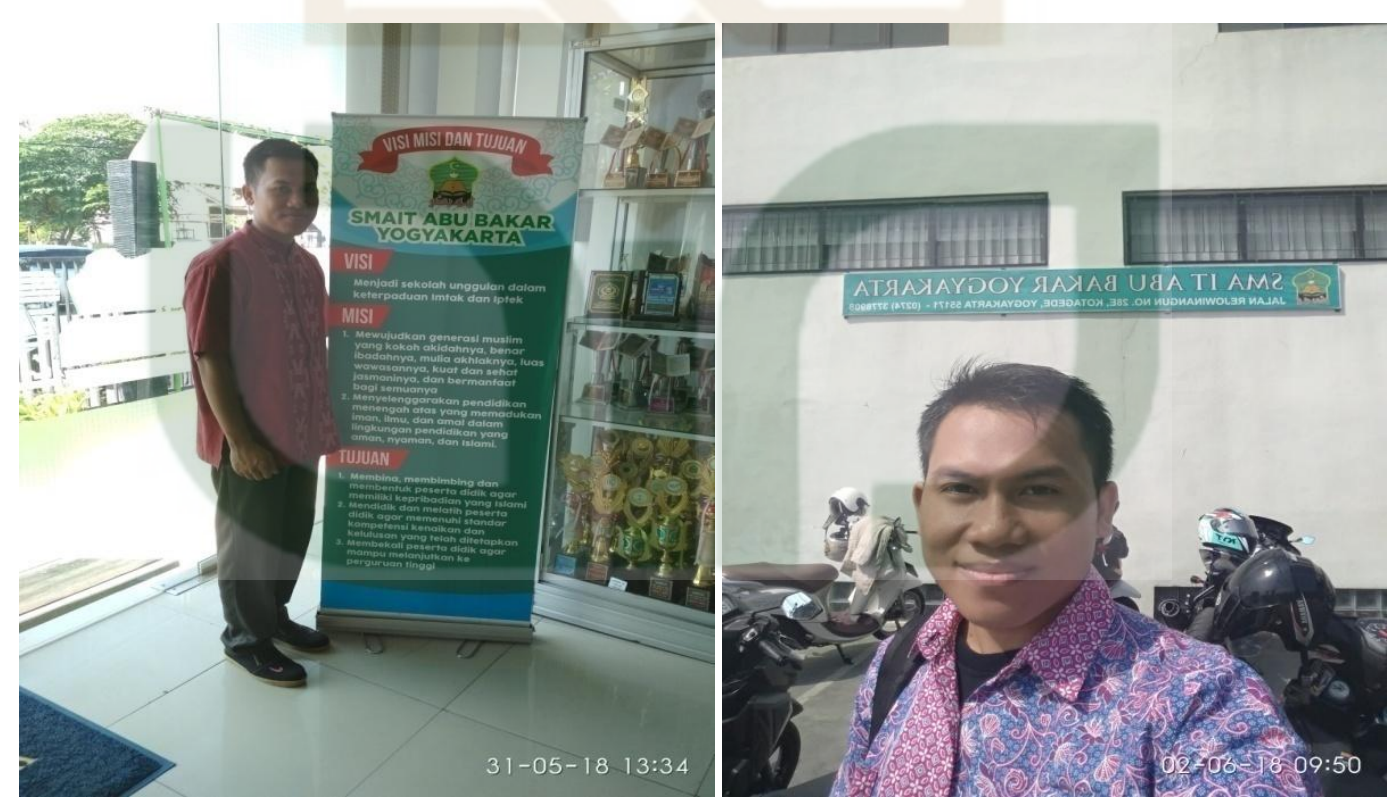

Gambar.06

Visi dan Misi SMA IT Abu Bakar Yogyakarta 


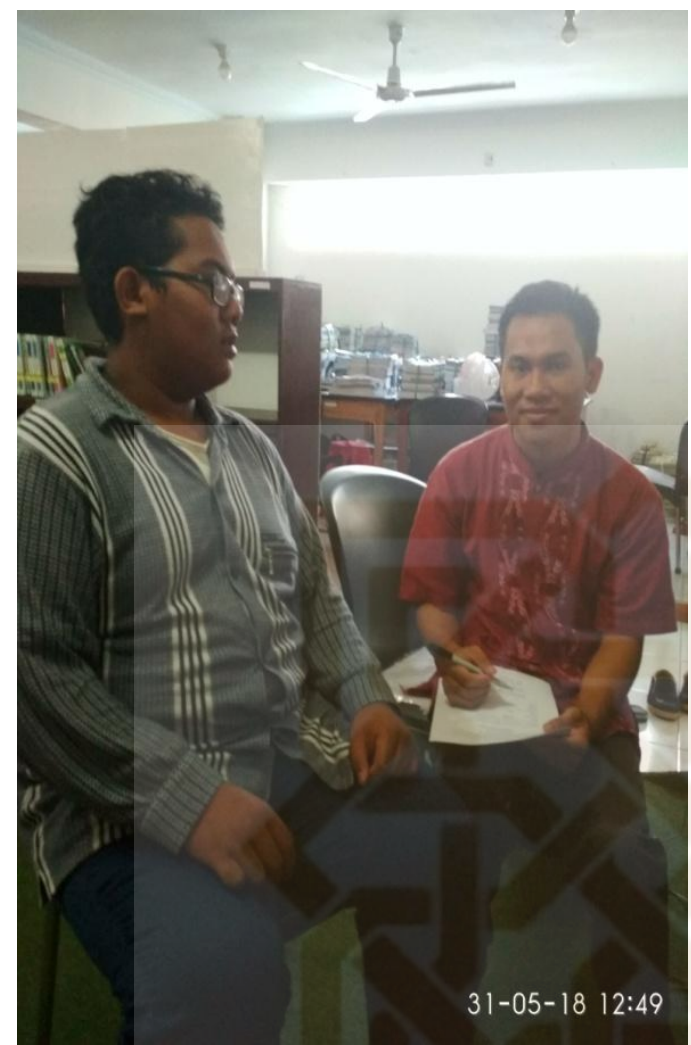

Wawancara Amiral Hidayat

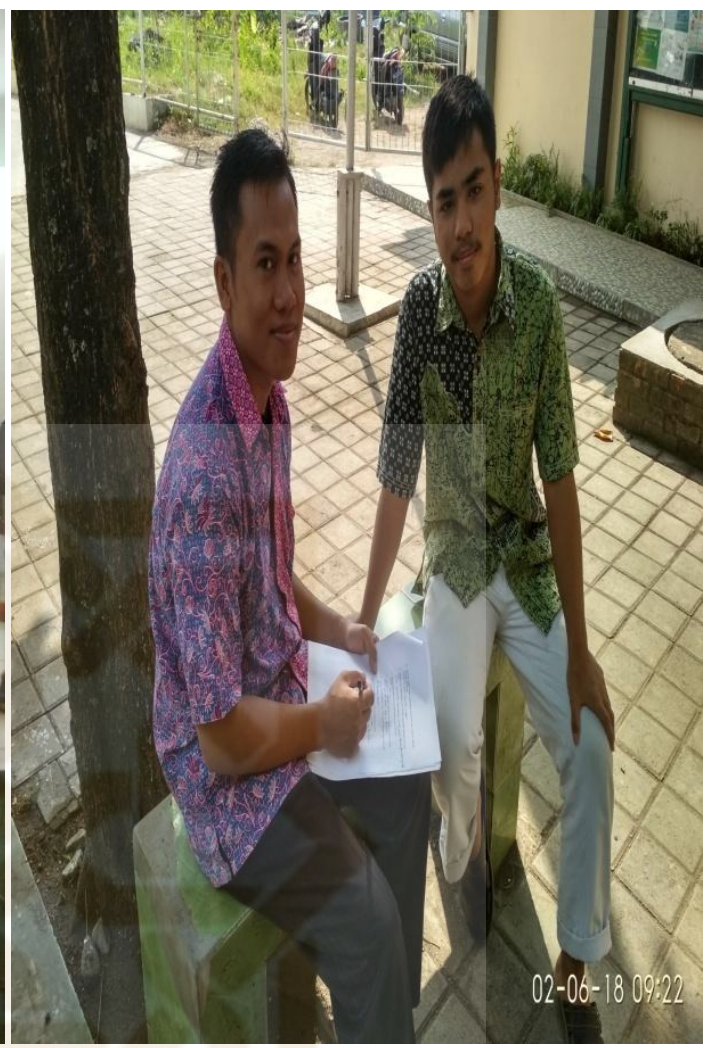

Gambar.07

Wawancara Zulfikar

SMA IT Abu Bakar Yogyakarta

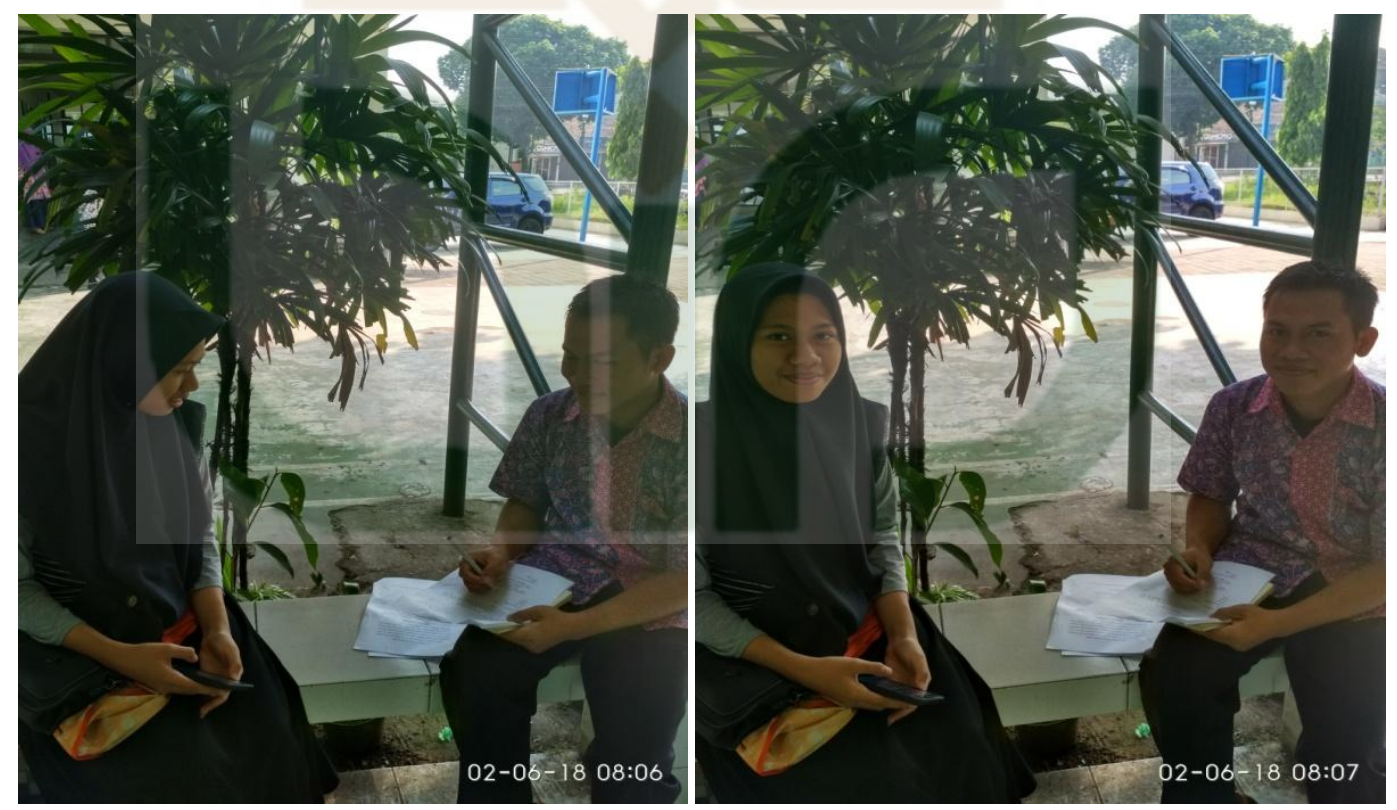

Gambar.08

Wawancara Tasya di halaman sekolah SMA IT Abu Bakar Yogyakarta 


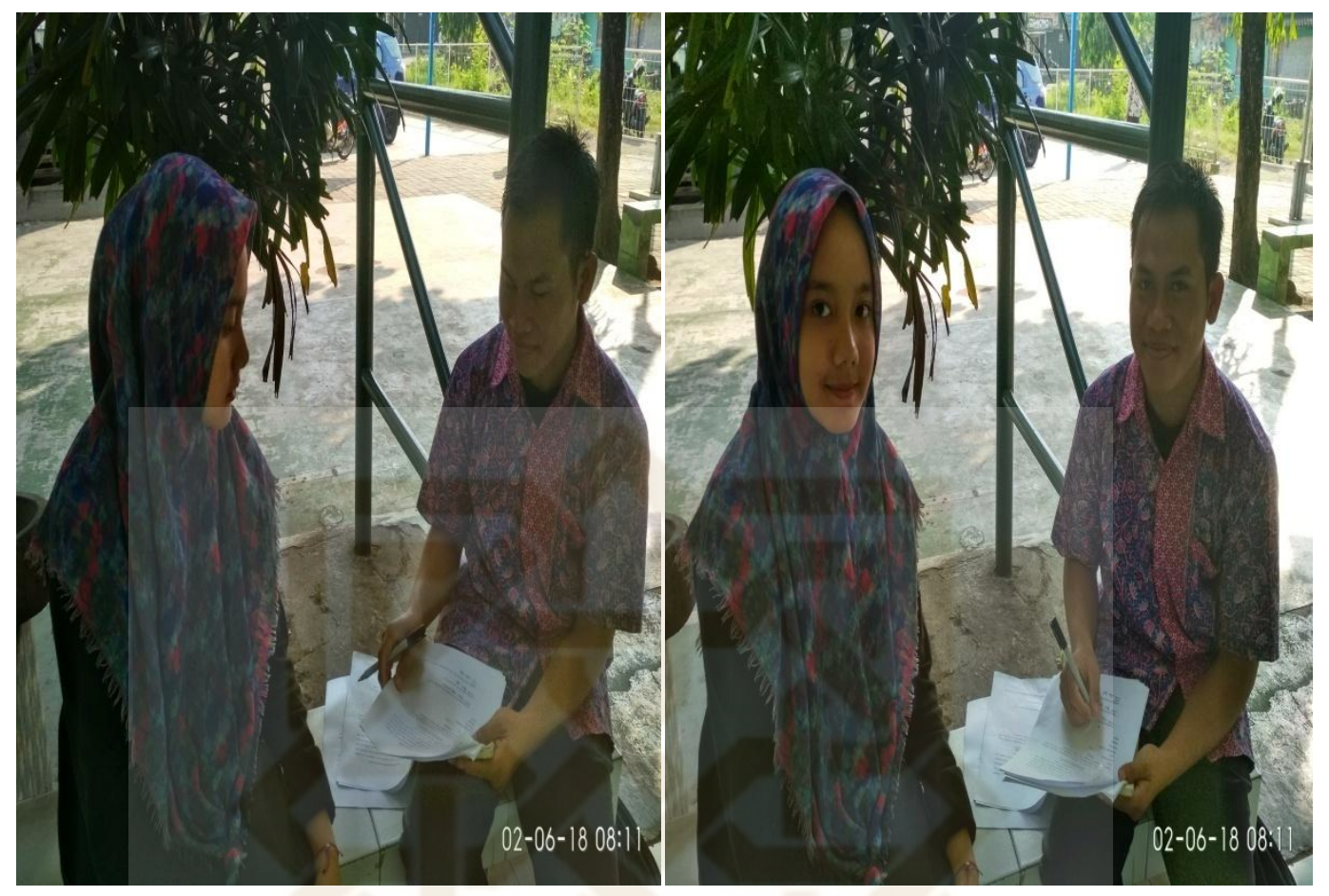

Gambar.09

Wawancara Salsa di halaman sekolah SMA IT Abu Bakar Yogyakarta

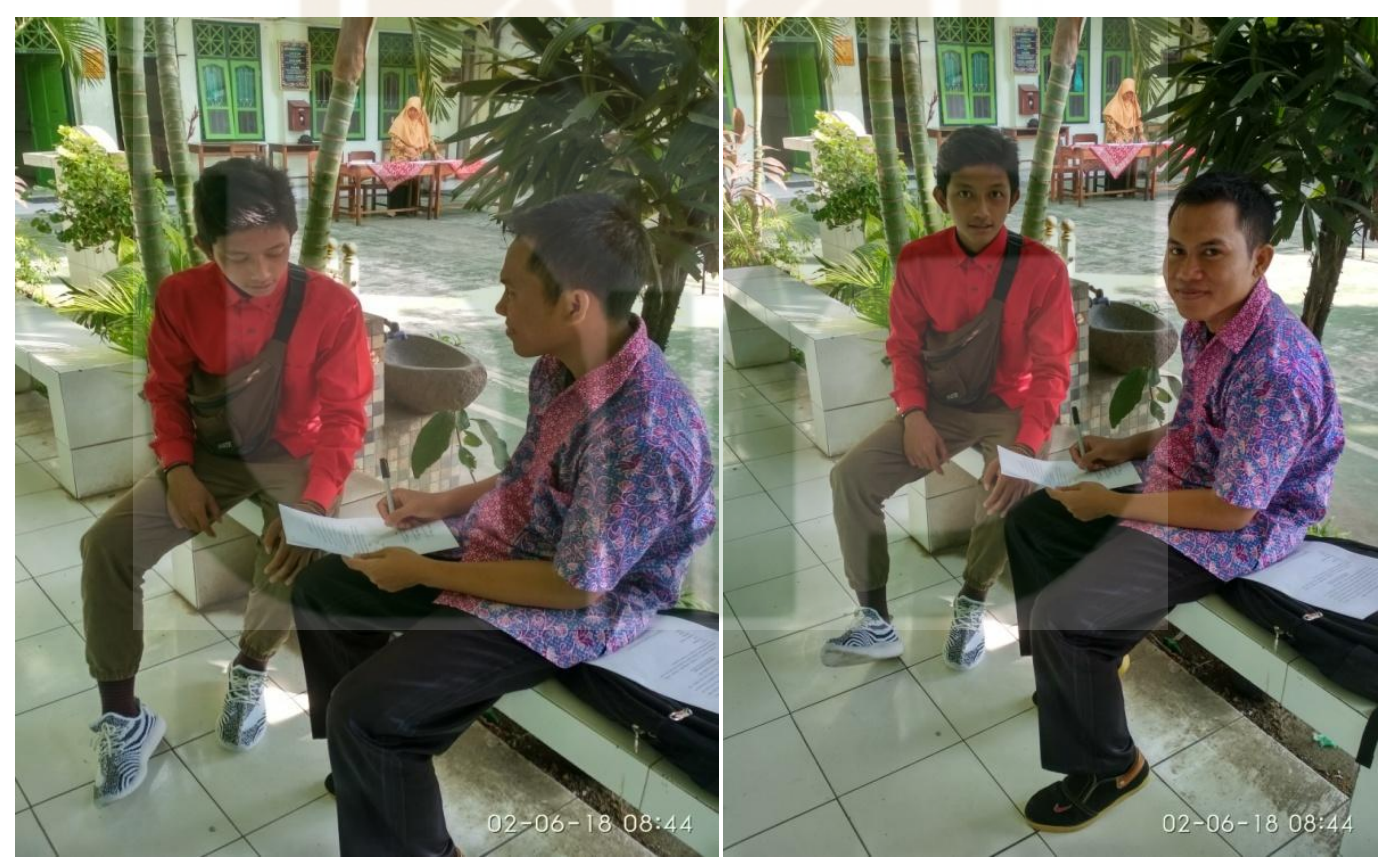

Gambar.10

Wawancara Faisal di halaman sekolah SMA IT Abu Bakar Yogyakarta 


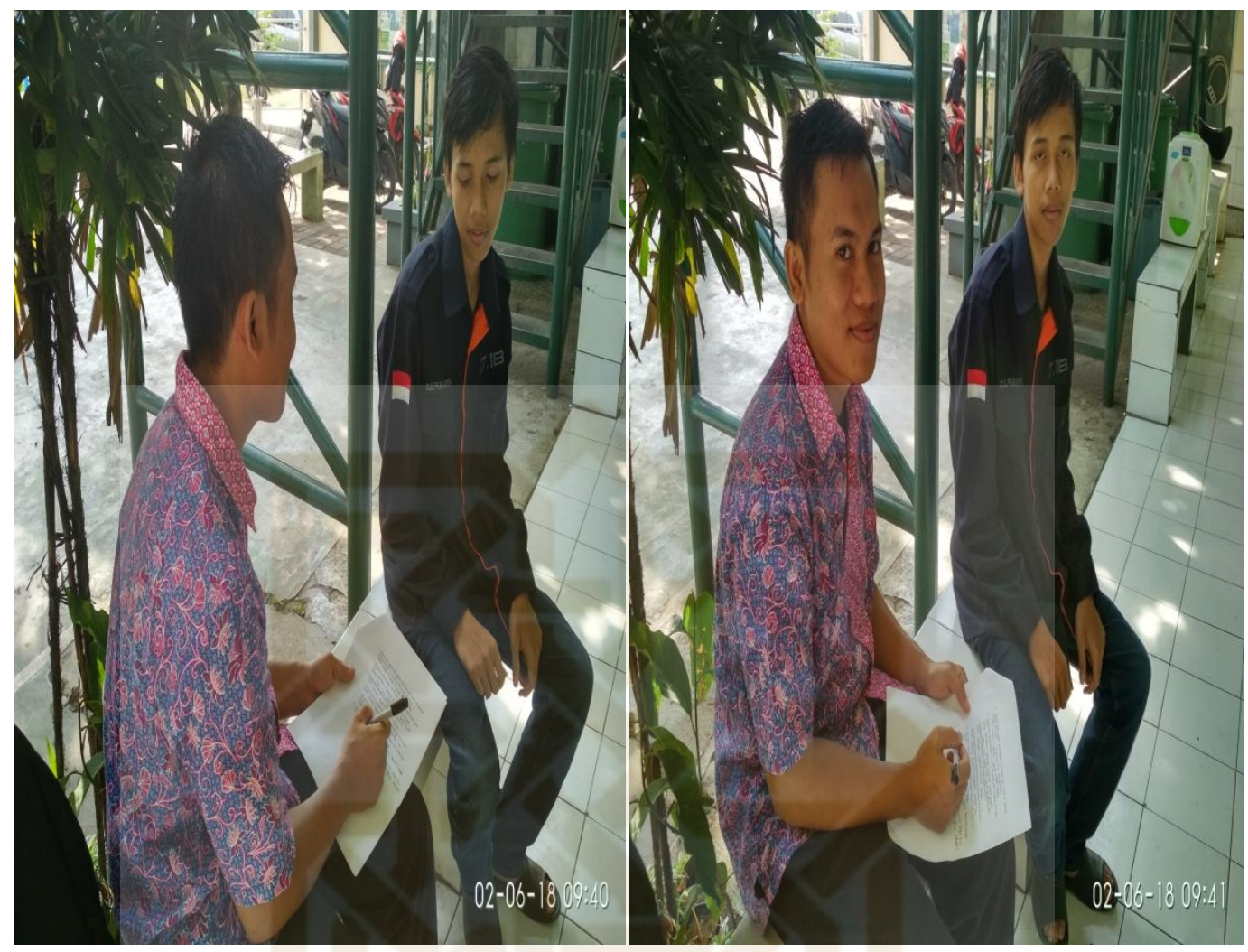

Gambar.11

Wawancara Zulfikar di halaman sekolah SMA IT Abu Bakar Yogyakarta

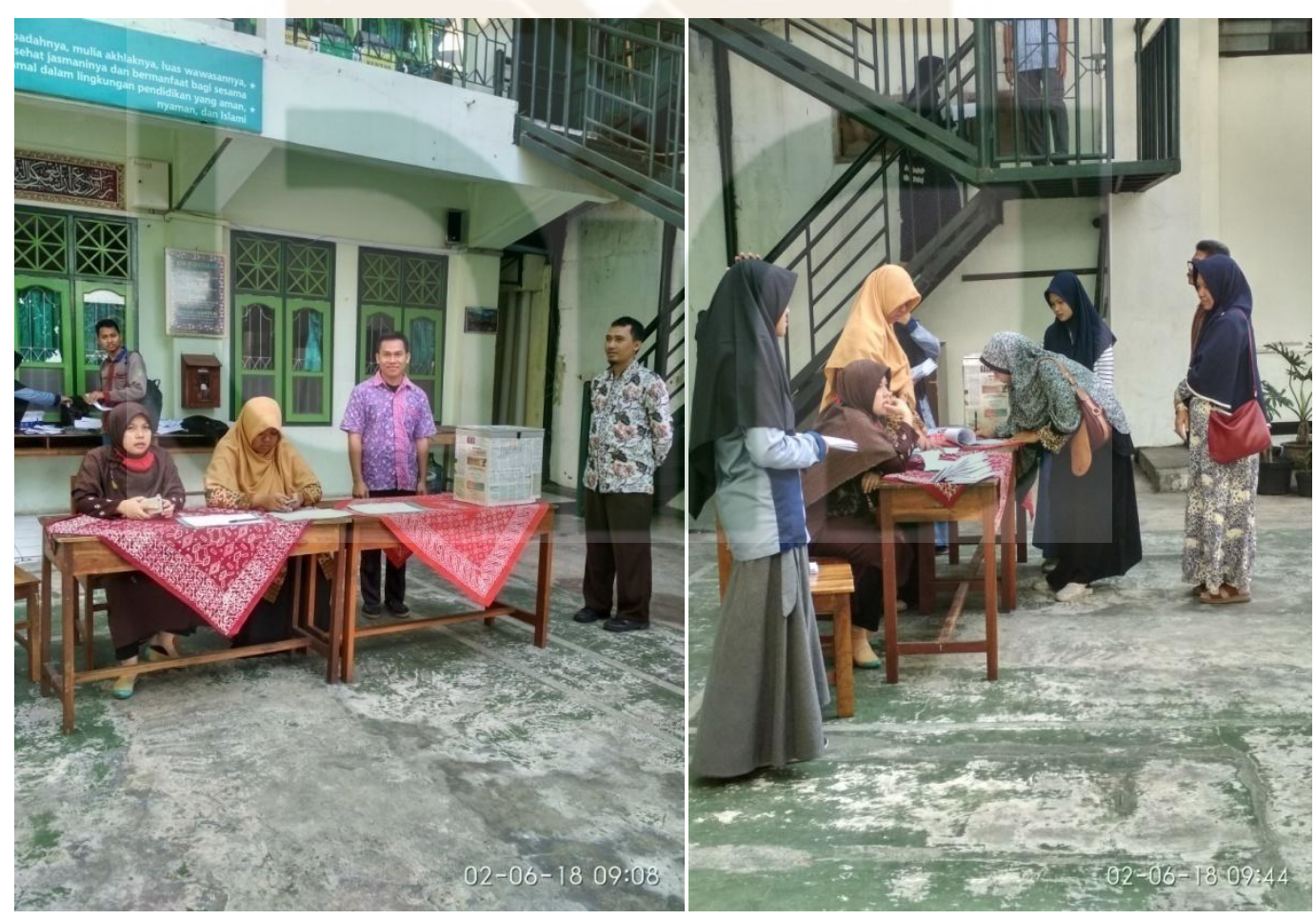

Gambar.12

Acara Pengambilan Rapot dan Infaq Sedekah di SMA IT Abu Bakar Yogyakarta 


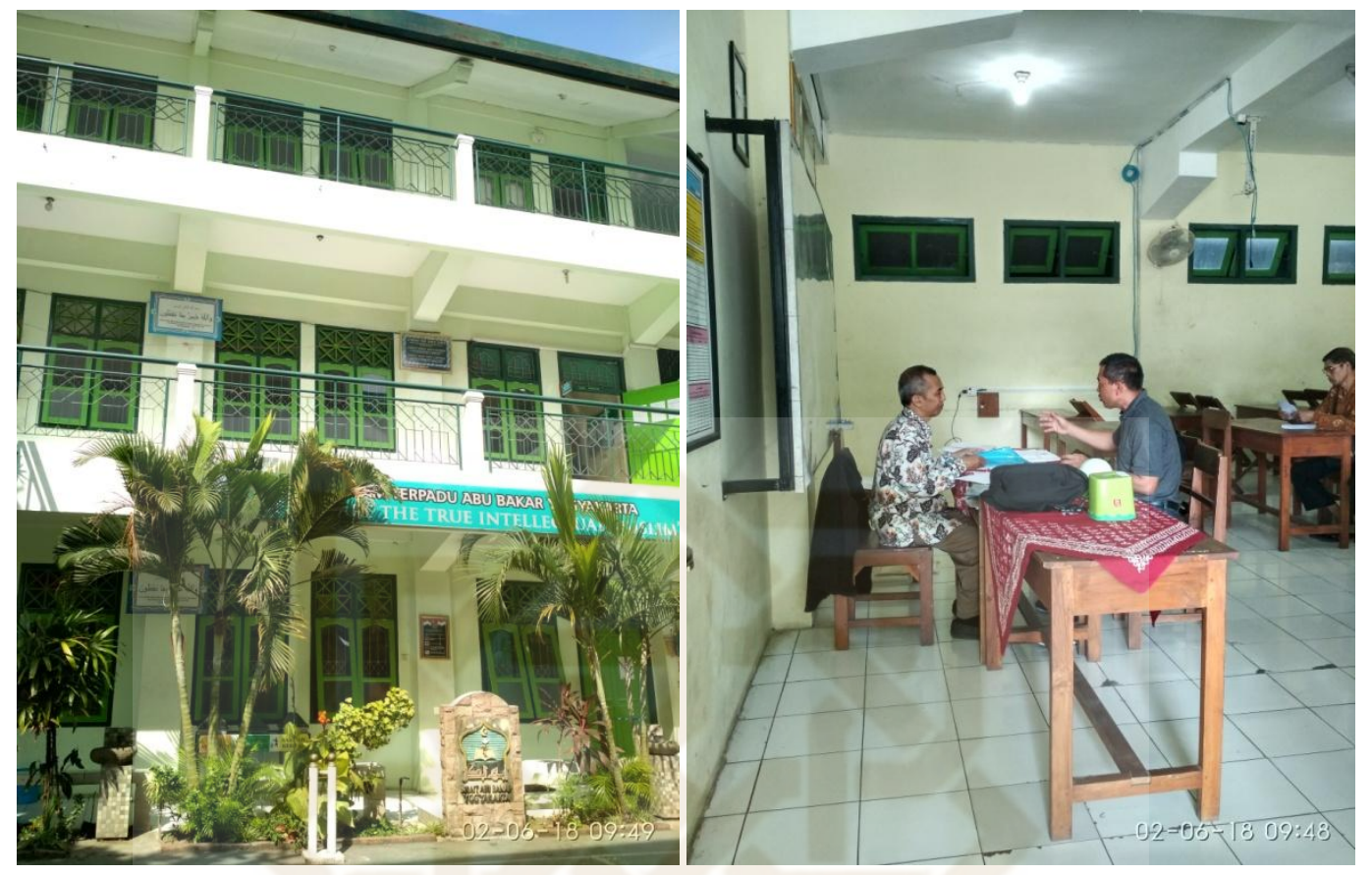

Gambar.13

Guru dan Wali murid sedang memberikan informasi bahwasannya ini hasil nilai anaknya selama belajar 1 semester

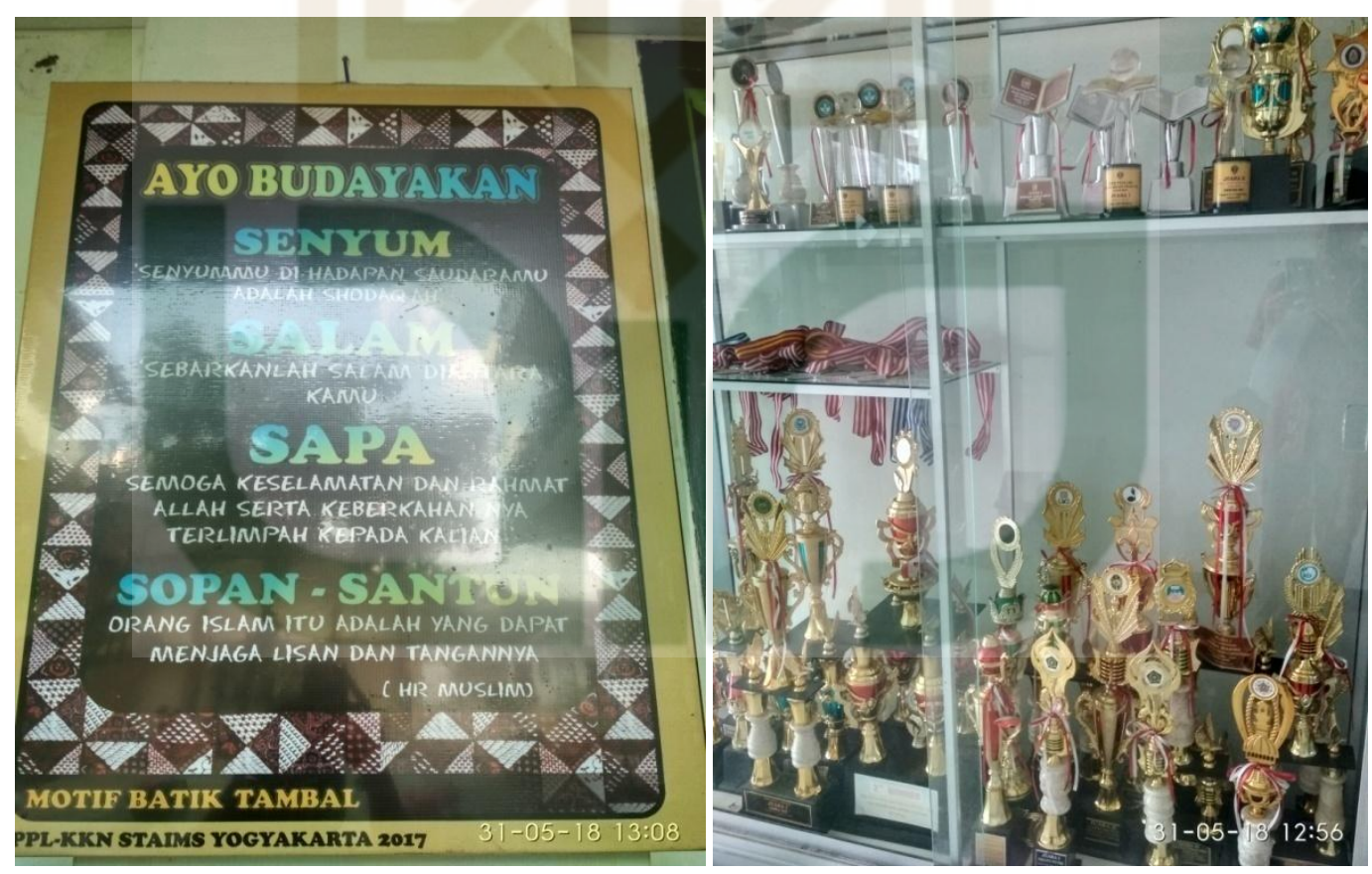

Gambar.14

Piala dan Penghargaan koleksi dari berbagai lomba yang di raih siswa siswi SMA IT Abu Bakar Yogyakarta 
KISI-KISI INSTRUMEN PENELITIAN

\begin{tabular}{|c|c|c|c|c|}
\hline No & Data & Sub Data & Sumber Data & $\begin{array}{l}\text { Metode } \\
\text { Penelitian }\end{array}$ \\
\hline \multirow[t]{9}{*}{1} & $\begin{array}{l}\text { Gambaran } \\
\text { umum SMA IT } \\
\text { Abu Bakar } \\
\text { Yogyakarta }\end{array}$ & $\begin{array}{l}\text { Profil SMA IT Abu } \\
\text { Bakar Yogyakarta }\end{array}$ & $\begin{array}{l}\text { Kepala } \\
\text { sekolah SMA } \\
\text { IT Abu Bakar } \\
\text { Yogyakarta }\end{array}$ & $\begin{array}{l}\text { Observasi } \\
\text { Wawancara } \\
\text { Dokumentasi }\end{array}$ \\
\hline & & Letak dan geografis & Dokumen & $\begin{array}{l}\text { Observasi } \\
\text { Dokumentasi }\end{array}$ \\
\hline & & $\begin{array}{l}\text { Sejarah berdiri dan } \\
\text { proses } \\
\text { perkembangannya }\end{array}$ & $\begin{array}{l}\text { Kepala } \\
\text { sekolah dan } \\
\text { dokumen }\end{array}$ & $\begin{array}{l}\text { Wawancara } \\
\text { Dokumentasi }\end{array}$ \\
\hline & & $\begin{array}{l}\text { Tujuan, Visi, Misi } \\
\text { SMA IT Abu } \\
\text { Bakar Yogyakarta }\end{array}$ & $\begin{array}{l}\text { Kepala } \\
\text { sekolah dan } \\
\text { dokumenta }\end{array}$ & $\begin{array}{l}\text { Wawancara } \\
\text { dan } \\
\text { Dokumen }\end{array}$ \\
\hline & & Struktur Organisasi & Staff TU & Dokumentasi \\
\hline & & $\begin{array}{l}\text { Sistem pendidikan } \\
\text { SMA IT Abu } \\
\text { Bakar Yogyakarta }\end{array}$ & $\begin{array}{l}\text { Kepala } \\
\text { sekolah waka } \\
\text { kurikulum } \\
\end{array}$ & $\begin{array}{l}\text { Wawancara } \\
\text { Dokumentasi }\end{array}$ \\
\hline & & $\begin{array}{l}\text { Kurikulum } \\
\text { integratif }\end{array}$ & $\begin{array}{l}\text { Waka } \\
\text { kurikulum }\end{array}$ & $\begin{array}{l}\text { Wawancara } \\
\text { Dokumentasi }\end{array}$ \\
\hline & & $\begin{array}{l}\text { Keadaan guru, } \\
\text { karyawan dan } \\
\text { peserta didik }\end{array}$ & Staff TU & Dokumentasi \\
\hline & & $\begin{array}{l}\text { Keadaan sarana } \\
\text { dan prasarana }\end{array}$ & Staff TU & Dokumentasi \\
\hline \multirow[t]{4}{*}{2} & $\begin{array}{l}\text { Konsep } \\
\text { karakteristik } \\
\text { komunikasi } \\
\text { edukatif dalam } \\
\text { pemaduan } \\
\text { iman, ilmu dan } \\
\text { amal }\end{array}$ & $\begin{array}{l}\text { Kegiatan } \\
\text { intrakurikuler, } \\
\text { ekstrakurikuler }\end{array}$ & $\begin{array}{l}\text { Waka } \\
\text { kurikulum, } \\
\text { guru }\end{array}$ & $\begin{array}{l}\text { Observasi } \\
\text { Wawancara } \\
\text { Dokumentasi }\end{array}$ \\
\hline & & $\begin{array}{l}\text { Pemaduan } \\
\text { iman,ilmu dan } \\
\text { amal }\end{array}$ & $\begin{array}{l}\text { Waka } \\
\text { kurikulum, } \\
\text { guru }\end{array}$ & $\begin{array}{l}\text { Observasi } \\
\text { Wawancara } \\
\text { Dokumentasi }\end{array}$ \\
\hline & $\begin{array}{l}\text { Strategi } \\
\text { pembelajaran } \\
\text { komunikasi } \\
\text { edukatif dalam } \\
\text { pemaduan } \\
\text { iman, ilmu dan } \\
\text { amal }\end{array}$ & $\begin{array}{l}\text { Pembelajaran } \\
\text { kontekstual }\end{array}$ & Guru & $\begin{array}{l}\text { Observasi } \\
\text { Wawancara } \\
\text { Dokumentasi }\end{array}$ \\
\hline & & Implementasi & Guru & Observasi \\
\hline
\end{tabular}




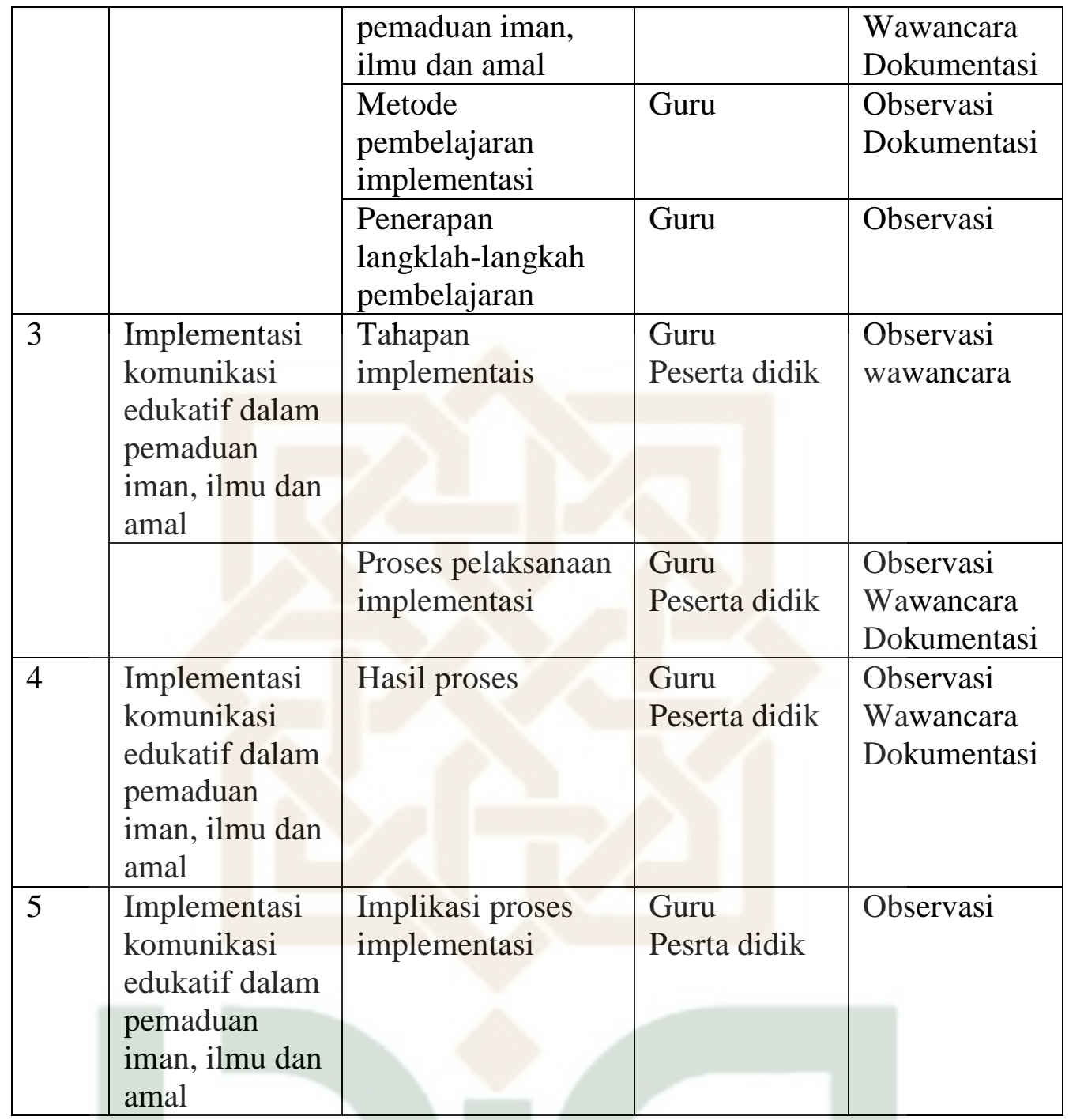


JADWAL OBSERVASI PENELITIAN

\begin{tabular}{|c|c|c|}
\hline $\mathrm{NO}$ & Tanggal & Keterangan \\
\hline & Senin, 4 Juli 2018 & $\begin{array}{l}\text { Mengirim surat Penelitian kebagian TU } \\
\text { SMA IT Abu Bakar Yogyakarta }\end{array}$ \\
\hline & Selasa, 5 Juli 2018 & $\begin{array}{l}\text { Wawancara dengan Ibu Nurhasanah selaku } \\
\text { guru PAI SMA IT Abu Bakar } \\
\text { Yogyakartawaktu Pra Observasi }\end{array}$ \\
\hline & Senin, 22 Juli 2018 & Observasi lokasi penelitian \\
\hline & Jum'at, 26 Juli 2018 & $\begin{array}{l}\text { Wawancara dengan Bapak Kuswanto selaku } \\
\text { guru PAI kelas } 12 \text { SMA IT Abu Bakar } \\
\text { Yogyakarta }\end{array}$ \\
\hline & Senin, 6 Agustus & $\begin{array}{l}\text { Wawancara dengan Bapak Dedi selaku guru } \\
\text { PAI Kelas } 11 \text { SMA IT Abu Bakr } \\
\text { Yogyakarta }\end{array}$ \\
\hline & Selasa, 7 Agustus & $\begin{array}{l}\text { observasi di lingkungan kelas SMA IT Abu } \\
\text { Bakar Yogyakarta }\end{array}$ \\
\hline & Rabu, 8 Agustus & $\begin{array}{l}\text { Observasi pada pembelajaran tema Iman } \\
\text { kepada Allah bersama Ibu Nurhasanah }\end{array}$ \\
\hline & Kamis,9 Agustus & $\begin{array}{l}\text { Dokumentasi data SMA IT Abu Bakar dan } \\
\text { observasi bersama Ibu Nurhasanah }\end{array}$ \\
\hline & Jum'at, 10 Agustus & Observasi proses pembelajaran di kelas \\
\hline & Senin, 13 Agustus & $\begin{array}{l}\text { Observasi dikelas } 2 \text { dan juga halam kelas } \\
\text { serta wawancara dengan Ibu Nurhasanah }\end{array}$ \\
\hline & Selasa, 14 Agustus & $\begin{array}{l}\text { Dokumentasi SMA IT Abu Bakar } \\
\text { Yogyakarta di depan halaman sekolah }\end{array}$ \\
\hline & Rabu, 15 Agustus & $\begin{array}{l}\text { Dokumentasi profil SMA IT Abu Bakar } \\
\text { Yogyakarta dari koleksi album }\end{array}$ \\
\hline & Kamis, 16 Agustus & $\begin{array}{l}\text { Wawancara dengan Faisal siswa SMA IT } \\
\text { Abu Bakar Yogyakarta }\end{array}$ \\
\hline & Kamis, 16 Agustus & $\begin{array}{l}\text { Wawancara dengan Amirul Hidayat siswa } \\
\text { SMA IT Abu Bakar Yogyakarta }\end{array}$ \\
\hline & Senin, 20 Agustus & $\begin{array}{l}\text { Wawancara dengan Zulfikar siswa SMA IT } \\
\text { Abu Bakar Yogyakarta }\end{array}$ \\
\hline & Senin, 20 Agustus & $\begin{array}{l}\text { Wawancara dengan Mustofa siswa SMA IT } \\
\text { Abu Bakar Yogyakarta }\end{array}$ \\
\hline & Selasa, 21 Agustus & $\begin{array}{l}\text { Wawancara dengan Tasya siswi SMA IT } \\
\text { Abu Bakar Yogyakarta }\end{array}$ \\
\hline & Rabu, 22 Agustus & $\begin{array}{l}\text { Wawancara dengan Salsa siswi SMA IT } \\
\text { Abu Bakar Yogyakarta }\end{array}$ \\
\hline & Rabu, 22 Agustus & $\begin{array}{l}\text { Dokumentasi visi dan misi SMA IT Abu } \\
\text { Bakar Yogyakarta }\end{array}$ \\
\hline & Jum'at 24 Agustus & $\begin{array}{l}\text { Dokumentasi piala penghargaan yang diraih } \\
\text { SMA IT Abu Bakar Yogyakarta }\end{array}$ \\
\hline & Senin, 27 Agustus & SMA IT Abu Bakar Yogyakarta \\
\hline
\end{tabular}




\begin{tabular}{|l|l|l|}
\hline & Selasa, 28 Agustus & $\begin{array}{l}\text { Dokumentasi kegiatan pembagian rapot dan } \\
\text { infaq wali santri }\end{array}$ \\
\hline & Kamis, 29 Agustus & $\begin{array}{l}\text { Dokumentasi halaman sekolah SMA IT Abu } \\
\text { Bakar Yogyakarta }\end{array}$ \\
\hline Jum'at, 31Agustus & $\begin{array}{l}\text { Observasi pada kegiatan ekstrakurikuler } \\
\text { SMA IT Abu Bakar Yogyakarta }\end{array}$ \\
\hline
\end{tabular}

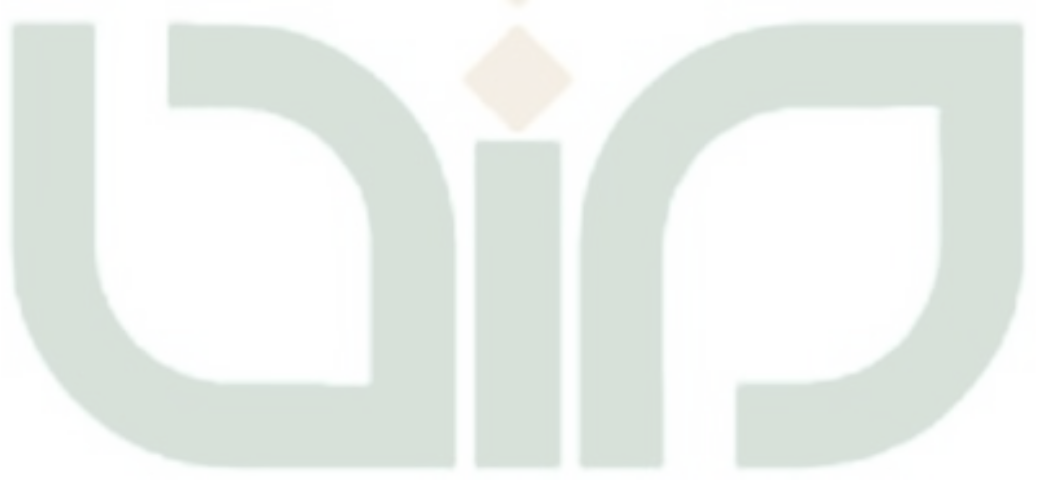




\section{ALAT PENGUMPULAN DATA (APD)}

Item pertanyaan ini yang digunakan untuk memperoleh data mengenai implementasi komunikasi edukatif dalam pemaduan iman, ilmu dan amal. Studi pembelajaran PAI di SMA IT Abu Bakar Yogyakarta, jawaban yang anda berikan secara objektif sangat membantu keberhasilan peneliti ini, dan merupakan sumbangsi bagi perkembangan ilmu, dan jawaban yang anda berikan tidak berhubungan dengan nama baik anda atau merugikan anda.

\section{PEDOMAN WAWANCARA}

(Ditujukan Kepada Guru PAI)

Pedoman wawancara ini bertujuan mendapatkan informasi tentang implementasi komunikasi edukatif dalam pemaduan iman, ilmu dan amal. Studi pembelajaran PAI di SMA IT Abu Bakar Yogyakarta:

Nama : Ibu Nur Hasanah, M.Ag.

Jenis Kelamin : Perempuan

Umur : 45Thn

Pendidikan Terakhir :S2 (UIN Sunan Kalijaga Yogyakarta)

Pekerjaan : Guru PAI

Tanggal : 31 Mei 2018

Waktu $: 11: 28$

1. Sejak kapan Bapak/Ibu menjadi guru PAI di SMA IT Abu Bakar Yogyakarta?

Jawab: 1997 sampai sekarang

2. Apa pekerjaan Bapak/Ibu selain menjadi guru PAI di SMA IT Abu Bakar Yogyakarta?

Jawab: Ibu Rumah Tangga

3. Bagaimana konsep implementasi komunikasi edukatif dalam pembelajaran PAI di SMA IT Abu Bakar Yogyakarta?

Jawab: Dalam pembelajaran PAI sebelum pembelajaran harus menyiapkan konsep dan tema dalam pembelajaran, harus bisa ngomong, lancar dalam menjelaskan materi dan bisa komunikasi dengan peserta didik lancar 
4. Bagaimana cara Bapak/Ibu dalam memadukan iman, ilmu dan amal dalam pembelajaran PAI di SMA IT Abu Bakar Yogyakarta?

Jawab: caranya adalah dengan kegiatan belajar, memahamkan konsepkonsep tentang iman, ilmu dan amal, supaya anak mampu mengumpulkan dan berusaha mengerjakan tugas yang saya berikan kepada murid dan memberi tugas supaya anak paham apa itu iman, ilmu dan Amal

5. Apasaja iman, ilmu dan amal yang sudah diterapkan di SMA IT Abu Bakar Yogyakarta?

Jawab: sudah di terapkan seperti penumbuh kembangkan iman, ilmu dan amal islami, shalat duha, literasi, setiap kegiatan harus di awali dengan bismilah dan do'a dan mengakhiri kegiatan dengan doa dan salam dan harus disiplin

6. Apa hasil dari pemaduan iman, ilmu dan amal selain pembelajaran PAI?

Jawab: hasilnya adalah anak terbiasa shalat berjama'ah, ada kegiatan mentoring yang memberikan pembelajaran agama dan bisa mengetahui kopetensi yang dimiliki siswa

7. Cirikhas dari sekolah SMA IT Abu Bakar Yogyakarta ini apa aja dan yang berbeda dari SMA yang ada di Yogyakarta?

Jawab: yang membedakan dari SMA yang ada di Yogyakarta adalah keterpaduan islamik intergiti

8. Apa saja kontri busi lembaga pendidik dalam implementasi komunikasi edukatif dalam pemaduan iman, ilmu dan amal. Di SMA IT Abu Bakar Yogyakarta?

Jawab: kontribusinya adalah konsepya jelas KYM yaitu konsursium yayasan mulia mengawal dan mengelola yayasan dari konsep pembelajaran

9. Program apa saja yang digunakan untuk implementasi komunikasi edukatif dalam pemaduan iman, ilmu dan amal. Studi pembelajaran PAI di SMA IT Abu Bakar Yogyakarta?

Jawab: programnya adalah pukul 7:30 semua siswa sudah di dalam kelas dan membaca do'a dan tadarus al-Qur'an, setiap hari jumat bagi yang 
putra wajib shalat jum'at, puasa senin kamis, makan bersama, mengadakan peringatan hari besar seperti pesantren kilat di bulan romadhon, bakti amal sosial dan di SMA IT Abu Bakar Yogyakarta tidak mengenal hari setiap hari ada program Islami

10. Apa saja pengaruh implementasi komunikasi edukatif pemaduan iman, ilmu dan amal dalam pembelajaran PAI di SMA IT Abu Bakar Yogyakarta?

Jawab: pengaruhnya besar PAI dari berbagai sisih dari segi shalat berjama'ah, lembar kontrol dan akhlakulkarimah

11. Metode apa saja yang digunakan dalam implementasi komunikasi Edukatif dalam pemaduan iman ilmu dan amal. Studi pembelajaran PAI di SMA IT Abu Bakar Yogyakarta?

Jawab: metode yang digunakan banyak membangun pemahaman, diskusi, ceramah, proyek, riset, direk method, pembiasaan

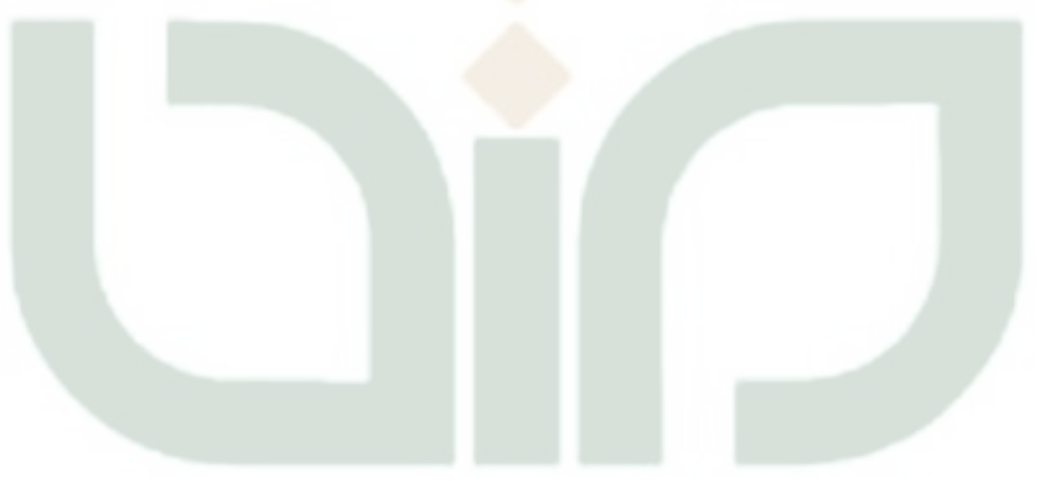




\section{ALAT PENGUMPULAN DATA (APD)}

Item pertanyaan ini yang digunakan untuk memperoleh data mengenai implementasi komunikasi edukatif dalam pemaduan iman, ilmu dan amal. Studi pembelajaran PAI di SMA IT Abu Bakar Yogyakarta, jawaban yang anda berikan secara objektif sangat membantu keberhasilan peneliti ini, dan merupakan sumbangsi bagi perkembangan ilmu, dan jawaban yang anda berikan tidak berhubungan dengan nama baik anda atau merugikan anda.

\section{PEDOMAN WAWANCARA}

(Ditujukan Kepada Guru PAI)

Pedoman wawancara ini bertujuan mendapatkan informasi tentang implementasi komunikasi edukatif dalam pemaduan iman, ilmu dan amal. Studi pembelajaran PAI di SMA IT Abu Bakar Yogyakarta:

$\begin{array}{ll}\text { Nama } & : \text { Bapak Arif Utomo, S.Ag. } \\ \text { Jenis Kelamin } & : \text { Laki-laki } \\ \text { Umur } & : \text { 46Thn }\end{array}$

Pendidikan Terakhir : S1 UIN Sunan Kalijaga Yogyakarta

$\begin{array}{ll}\text { Pekerjaan } & : \text { Guru PAI } \\ \text { Tanggal } & : 31 \text { Mei } 2018 \\ \text { Waktu } & : 12: 32\end{array}$

1. Sejak kapan Bapak/Ibu menjadi guru PAI di SMA IT Abu Bakar Yogyakarta?

Jawab: 1995 sampai sekarang

2. Apa pekerjaan Bapak/Ibu selain menjadi guru PAI di SMA IT Abu Bakar Yogyakarta?

Jawab: Penceramah

3. Bagaimana konsep implementasi komunikasi edukatif dalam pembelajaran PAI di SMA IT Abu Bakar Yogyakarta?

Jawab: dalam pembelajaran PAI mengambil materi dengan menghubungkan kehidupan sekarang misalkan dalam menganalisis anak di zaman yang modern dalam pembelajaran PAI harus mengambil contoh 
dalam kehidupan di zaman modern sekarang contohnya ada kejadian gunung meletus, dan ada komunikasi dengan murid lancar

4. Bagaimana cara Bapak/Ibu dalam memadukan iman, ilmu dan amal dalam pembelajaran PAI di SMA IT Abu Bakar Yogyakarta?

Jawab: caranya adalah memberikan pendidikan iman, ilmu dan amal dari dasar apa itu iman, ilmu dan amal dan mengaplikasikan dalam masyarakat dan kehidupan sehari-hari dan di jelaskan iman itu pokok ya, ilmu itu caranya dan amal itu pengaplikasiannya

5. Apasaja iman, ilmu dan amal yang sudah diterapkan di SMA IT Abu Bakar Yogyakarta?

Jawab: sudah di terapkan seperti memberikan pembelajaran tentang rukun iman, ilmu dan amal secara keseluruhan dan mengaplikasikan dalam kehidupan sehari-hari

6. Apa hasil dari pemaduan iman, ilmu dan amal selain pembelajaran PAI? Jawab: hasilnya adalah masih dalam proses karena dari berbagai latarbelakang sekolah ada yang sudah dan ada yang belum yang sudah mengamalkan iman, ilmu dan amal dalam berjalannya waktu pasti bisa mengamalkannya

7. Cirikhas dari sekolah SMA IT Abu Bakar Yogyakarta ini apa aja dan yang berbeda dari SMA yang ada di Yogyakarta?

Jawab: yang membedakan dari SMA yang ada di Yogyakarta adalah semua mata pelajaran dalam mengajarkan mengkaitkan dengan PAI

8. Apa saja kontri busi lembaga pendidik dalam implementasi komunikasi edukatif dalam pemaduan iman, ilmu dan amal. Di SMA IT Abu Bakar Yogyakarta?

Jawab: kontribusinya adalah Islam jadi ruh utama di SMA IT Abu Bakar Yogyakarta jadi semua guru seperti guru PAI

9. Program apa saja yang digunakan untuk implementasi komunikasi edukatif dalam pemaduan iman, ilmu dan amal. Studi pembelajaran PAI di SMA IT Abu Bakar Yogyakarta? 
Jawab: programmnya adalah seni keislaman kaligrafi, tilawah, hadroh, nasid, dan ada mentoring agama

10. Apa saja pengaruh implementasi komunikasi edukatif pemaduan iman, ilmu dan amal dalam pembelajaran PAI di SMA IT Abu Bakar Yogyakarta?

Jawab: pengaruhnya siswa melihat sosok guru yang di sukai bagaimana kedekatan seorang guru kepada siswanya komunikasi edukatifnya

11. Metode apa saja yang digunakan dalam implementasi komunikasi Edukatif dalam pemaduan iman ilmu dan amal. Studi pembelajaran PAI di SMA IT Abu Bakar Yogyakarta?

Jawab: metode yang digunakan adalah ceramah, vidio, praktek, seperti ilmu ceramah, iman meto teladan dan amal praktik langsung

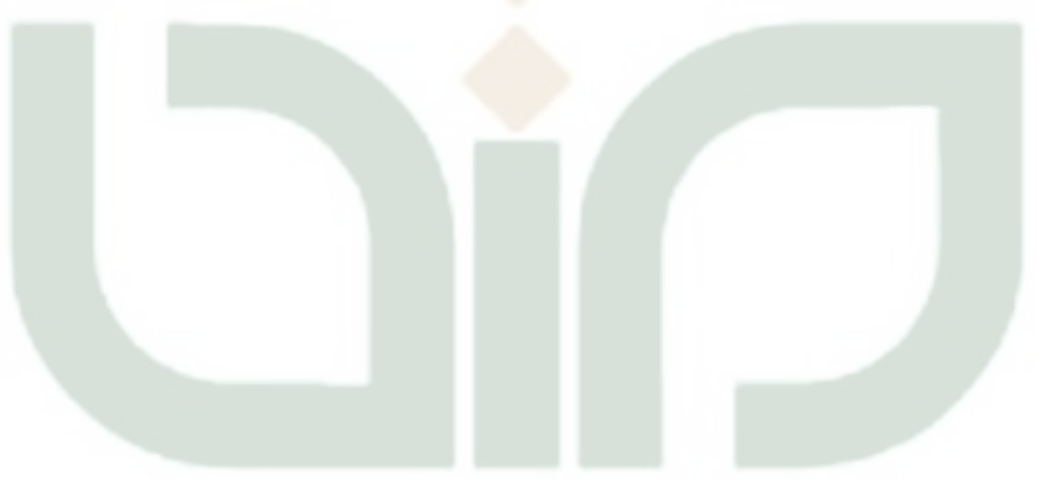




\section{ALAT PENGUMPULAN DATA (APD)}

Item pertanyaan ini yang digunakan untuk memperoleh data mengenai implementasi komunikasi edukatif dalam pemaduan iman, ilmu dan amal. Studi pembelajaran PAI di SMA IT Abu Bakar Yogyakarta, jawaban yang anda berikan secara objektif sangat membantu keberhasilan peneliti ini, dan merupakan sumbangsi bagi perkembangan ilmu, dan jawaban yang anda berikan tidak berhubungan dengan nama baik anda atau merugikan anda.

\section{PEDOMAN WAWANCARA}

(Ditujukan Kepada Guru PAI)

Pedoman wawancara ini bertujuan mendapatkan informasi tentang implementasi komunikasi edukatif dalam pemaduan iman, ilmu dan amal. Studi pembelajaran PAI di SMA IT Abu Bakar Yogyakarta:

Nama

: Wawan Kuswanto, S.Ag

Jenis Kelamin

: Laki-laki

Umur :30Thn

Pendidikan Terakhir :S1 UIN Sunan Kalijaga Yogyakarta

Pekerjaan : Guru PAI

Tanggal : 31 Mei 2018

Waktu $: 13: 27$

1. Sejak kapan Bapak/Ibu menjadi guru PAI di SMA IT Abu Bakar Yogyakarta?

Jawab: 2003 sampai sekarang

2. Apa pekerjaan Bapak/Ibu selain menjadi guru PAI di SMA IT Abu Bakar Yogyakarta?

Jawab: Penceramah

3. Bagaimana konsep implementasi komunikasi edukatif dalam pembelajaran PAI di SMA IT Abu Bakar Yogyakarta?

Jawab: konsep dalam pembelajaran PAI mengacu pada kurikulum JSIT dan penggabungan dinas contohnya dengan memadukan iman, ilmu dan amal 
4. Bagaimana cara Bapak/Ibu dalam memadukan iman, ilmu dan amal dalam pembelajaran PAI di SMA IT Abu Bakar Yogyakarta?

Jawab: caranya adalah menjelaskan iman, ilmu dan amal kepada anak salah satu hal yang di miliki anak dan memberikan kajian dalam dauroh yaitu forum kajian tematik

5. Apasaja iman, ilmu dan amal yang sudah diterapkan di SMA IT Abu Bakar Yogyakarta?

Jawab: sudah di terapkan seperti ilmu mengacunya ke kurikulum, keimanan kepada Allah, dinamakan akhlak, sejarah nabi sedangkan iman kepada rasul dan hari akhir dengan pembelajaran ini anak paham apa itu iman, ilmu dan amal

6. Apa hasil dari pemaduan iman, ilmu dan amal selain pembelajaran PAI?

Jawab: hasilnya adalah anak menjadi lebih kuat takwaya, kuat aqidahnya, mengetahui nilai-nilai islam dan ideologi yang lain seperti punya wawasan ma'rifat dan mempunyai adap kepada guru, teman, kedua orangtua

7. Cirikhas dari sekolah SMA IT Abu Bakar Yogyakarta ini apa aja dan yang berbeda dari SMA yang ada di Yogyakarta?

Jawab: pemaduan ilmu-ilmu pengetahuan dengan nilai-nilai agama contohnya dalam ilmu biologi

8. Apa saja kontri busi lembaga pendidik dalam implementasi komunikasi edukatif dalam pemaduan iman, ilmu dan amal. Di SMA IT Abu Bakar Yogyakarta?

Jawab: kontribusinya adalah dari SD, SMP, SMA yayasan bagaimana mengelola dari segi manajemen, fasilitas, litbang semuanya yang mengurusi yayasan sangat membantu dan kegiatan pembelajaran

9. Program apa saja yang digunakan untuk implementasi komunikasi edukatif dalam pemaduan iman, ilmu dan amal. Studi pembelajaran PAI di SMA IT Abu Bakar Yogyakarta?

Jawab: programnya adalah ada Boarding Scool, Full Day, Ekstrakulikuler, olahraga, robotik, jurnal, pramuka (kepanduan), mentoring membeking iman, ilmu dan amal 
10. Apa saja pengaruh implementasi komunikasi edukatif pemaduan iman, ilmu dan amal dalam pembelajaran PAI di SMA IT Abu Bakar Yogyakarta?

Jawab: pengaruhnya luar biasa jadi manusia yang hebat, jadi dokter yang mempunyai keimanan, ilmu dan amal yang bisa membantu pasyennya.

11. Metode apa saja yang digunakan dalam implementasi komunikasi Edukatif dalam pemaduan iman ilmu dan amal. Studi pembelajaran PAI di SMA IT Abu Bakar Yogyakarta?

Jawab: metode yang di gunakan adalah metode pemahaman, pembiasaan, pemantauan dengan adanya mentor, metode kegiatan seperti di pondok dan kemah nuasa IT

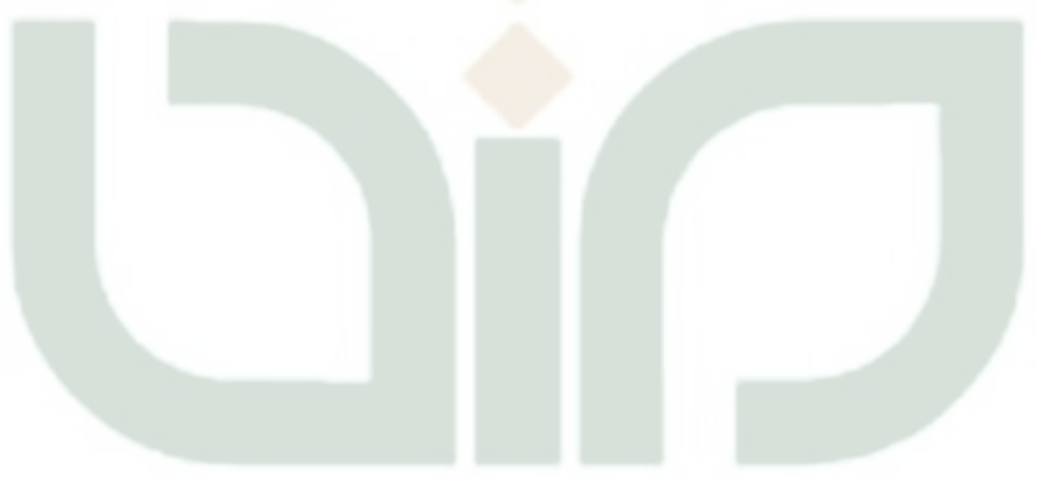




\section{ALAT PENGUMPULAN DATA (APD)}

Item pertanyaan ini yang digunakan untuk memperoleh data mengenai implementasi komunikasi edukatif dalam memadukan iman, ilmu dan amal. Studi pembelajaran PAI di SMA IT Abu Bakar Yogyakarta, jawaban yang anda berikan secara objektif sangat membantu keberhasilan peneliti ini, dan merupakan sumbangsi bagi perkembangan ilmu, dan jawaban yang anda berikan tidak berhubungan dengan nama baik anda atau merugikan anda.

\section{PEDOMAN WAWANCARA}

(Ditujukan kepada Siswa)/Siswi)

Pedoman wawancara ini bertujuan mendapatkan informasi tentang implementasi komunikasi edukatif dalam memadukan iman, ilmu dan amal. Studi pembelajaran PAI di SMA IT Abu Bakar Yogyakarta:

$\begin{array}{ll}\text { Nama } & \text { :Amirul Hidayat } \\ \text { Jenis Kelamin } & : \text { Laki-Laki } \\ \text { Umur } & : 17 \text { Thn } \\ \text { Kelas } & : \mathrm{X}^{1}\end{array}$

Status : Siswa SMA IT Abu Bakar Yogyakarta

\begin{tabular}{l|l} 
Tanggal & $: 2$ Juni 2018 \\
Waktu & $: 08: 44$
\end{tabular}

1. Pembelajaran PAI yang seperti apa yang anda senangi? Jawab: pembelajaran yang gurunya harus ada taya jawab, jangan monoton dalam pembelajaran PAI

2. Ekstra kulikuler apa yang anda ikuti?

Jawab: ekstrakulikuler yang saya ikuti mentoring yang tentang perjalanan Rosullah

3. Apakah ada ekstrakulikuler yang mengajarkan tentang iman, ilmu dan amal?

Jawab: ada seperti mentoring, murobi dan pengenalan tentang keislaman 
4. Apakah anda sudah menerapkan iman, ilmu dan amal di sekolah ataupun di rumah?

Jawab: sudah shalat lima waktu

5. Bagaimana pembelajaran PAI di kelas yang anda dapatkan dari guru PAI?

Jawab: yang saya dapatkan seperti tata cara shalat jenazah, khutbah jumat, menghargai pendapat orang lain

6. Bagaimana komunikasi edukatif anda dengan guru PAI? Jawab: baik dan lancar

7. Apa saja kegiat yang anda lakukan ketika pembelajaran PAI di kelas? Jawab: ketika pembelajaran PAI di kelas mendengarkan guru menjelaskan materi, mengerjakan tugas dan praktek

8. Apa saja yang di ajarkan Guru PAI? Jawab: yang di ajarkan rukun iman

9. Apa saja yang anda dapatkan dari pembelajaran PAI?

Jawab: bisa tau tentang Islam, ternyata khutbah jumat itu ada rukunrukunnya dan tatacara shalat jenazah

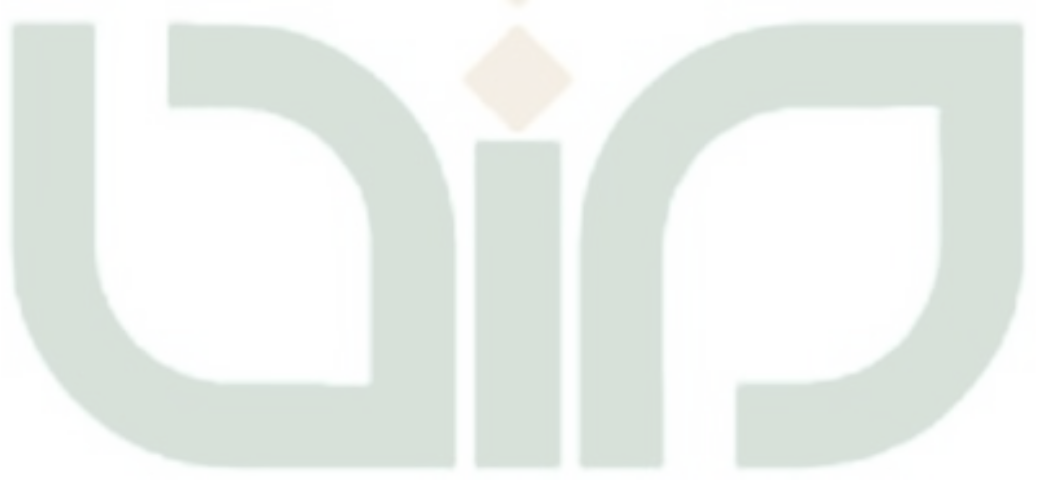




\section{ALAT PENGUMPULAN DATA (APD)}

Item pertanyaan ini yang digunakan untuk memperoleh data mengenai implementasi komunikasi edukatif dalam memadukan iman, ilmu dan amal. Studi pembelajaran PAI di SMA IT Abu Bakar Yogyakarta, jawaban yang anda berikan secara objektif sangat membantu keberhasilan peneliti ini, dan merupakan sumbangsi bagi perkembangan ilmu, dan jawaban yang anda berikan tidak berhubungan dengan nama baik anda atau merugikan anda.

\section{PEDOMAN WAWANCARA}

(Ditujukan kepada Siswa)/Siswi)

Pedoman wawancara ini bertujuan mendapatkan informasi tentang implementasi komunikasi edukatif dalam memadukan iman, ilmu dan amal. Studi pembelajaran PAI di SMA IT Abu Bakar Yogyakarta:

$\begin{array}{ll}\text { Nama } & : \text { Faisal } \\ \text { Jenis Kelamin } & : \text { Laki-Laki } \\ \text { Umur } & : \text { 17Thn } \\ \text { Kelas } & : \mathrm{X}^{1} \\ \text { Status } & : \text { Siswa SMA IT Abu Bakar Yogyakarta } \\ \text { Tanggal } & : 2 \text { Juni } 2018 \\ \text { Waktu } & : 12: 49\end{array}$

1. Pembelajaran PAI yang seperti apa yang anda senangi? Jawab: pembelajaran PAI yang di senangi praktek langsung dari pada teorori

2. Ekstra kulikuler apa yang anda ikuti?

Jawab: ekstrakulikuler yang saya ikuti Bahasa Inggris, Bahasa Arab dan nasid

3. Apakah ada ekstrakulikuler yang mengajarkan tentang iman, ilmu dan amal?

Jawab: ada seperti MTQ dan mapel mentoring 
4. Apakah anda sudah menerapkan iman, ilmu dan amal di sekolah ataupun di rumah?

Jawab: sudah shalat lima waktu gak bolos

5. Bagaimana pembelajaran PAI di kelas yang anda dapatkan dari guru PAI?

Jawab: yang saya dapatkan seperti pengetahuan Islam yang di dapatkan jadi tau agama Islam

6. Bagaimana komunikasi edukatif anda dengan guru PAI? Jawab:baik karna guru PAI wali kelas

7. Apa saja kegiat yang anda lakukan ketika pembelajaran PAI di kelas? Jawab: ketika pembelajaran PAI di kelas praktek, hapalan dan setoran surat-surat pendek

8. Apa saja yang di ajarkan Guru PAI?

Jawab: yang di ajarkan tentang rukun iman dan melihat kehidupan Rosullah

9. Apa saja yang anda dapatkan dari pembelajaran PAI? Jawab: menambah wawasan tentang Islam

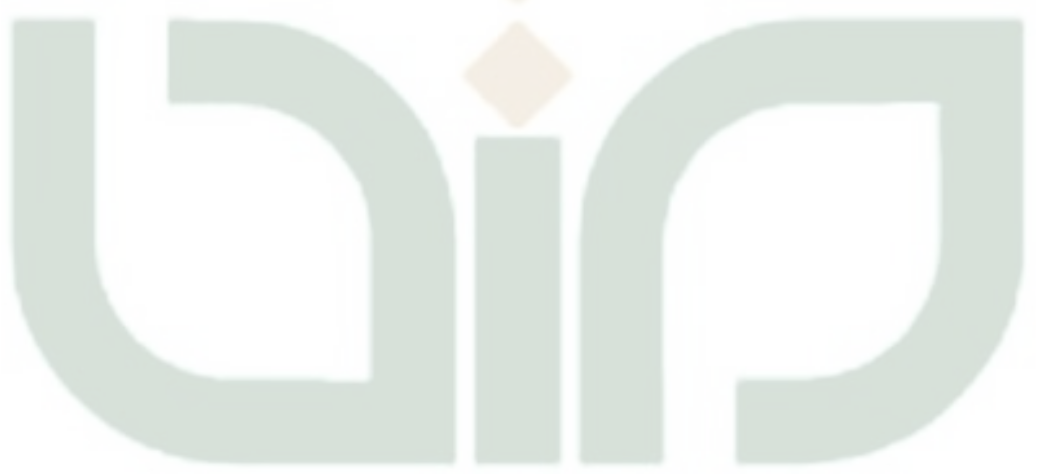




\section{ALAT PENGUMPULAN DATA (APD)}

Item pertanyaan ini yang digunakan untuk memperoleh data mengenai implementasi komunikasi edukatif dalam memadukan iman, ilmu dan amal. Studi pembelajaran PAI di SMA IT Abu Bakar Yogyakarta, jawaban yang anda berikan secara objektif sangat membantu keberhasilan peneliti ini, dan merupakan sumbangsi bagi perkembangan ilmu, dan jawaban yang anda berikan tidak berhubungan dengan nama baik anda atau merugikan anda.

\section{PEDOMAN WAWANCARA}

(Ditujukan kepada Siswa)/Siswi)

Pedoman wawancara ini bertujuan mendapatkan informasi tentang implementasi komunikasi edukatif dalam memadukan iman, ilmu dan amal. Studi pembelajaran PAI di SMA IT Abu Bakar Yogyakarta:

$\begin{array}{ll}\text { Nama } & : \text { Tasya } \\ \text { Jenis Kelamin } & : \text { Perempuan } \\ \text { Umur } & : \text { 17Thn } \\ \text { Kelas } & : \mathrm{X}^{1}\end{array}$

Status : : Siswi SMA IT Abu Bakar Yogyakarta

$\begin{array}{ll}\text { Tanggal } & : 2 \text { Juni } 2018 \\ \text { Waktu } & : 09: 41\end{array}$

1. Pembelajaran PAI yang seperti apa yang anda senangi? Jawab: pembelajaran PAI yang di senangi lebih kepenjelasan

2. Ekstra kulikuler apa yang anda ikuti? Jawab: ekstrakulikuler yang saya ikuti PMI dan BPI

3. Apakah ada ekstrakulikuler yang mengajarkan tentang iman, ilmu dan amal?

Jawab: ada BPI dan mentoring

4. Apakah anda sudah menerapkan iman, ilmu dan amal di sekolah ataupun di rumah?

Jawab: sudah contohya shalat lima waktu, ngaji dan hapalan 
5. Bagaimana pembelajaran PAI di kelas yang anda dapatkan dari guru PAI?

Jawab: yang saya dapatkan seperti materi akhlak, aqidah dan tata cara ibadah yang baik dan benar

6. Bagaimana komunikasi edukatif anda dengan guru PAI? Jawab: baik dan lancar

7. Apa saja kegiat yang anda lakukan ketika pembelajaran PAI di kelas? Jawab: ketika pembelajaran PAI di kelas dengerin guru menjelaskan materi dan kerja kelompok

8. Apa saja yang di ajarkan Guru PAI? Jawab: yang di ajarkan akidah akhlak dan kehidupan Rosullah.

9. Apa saja yang anda dapatkan dari pembelajaran PAI?

Jawab: banyak seperti akhlak dan sikap yang harus di terapkan dalam kehidupan sehari-hari

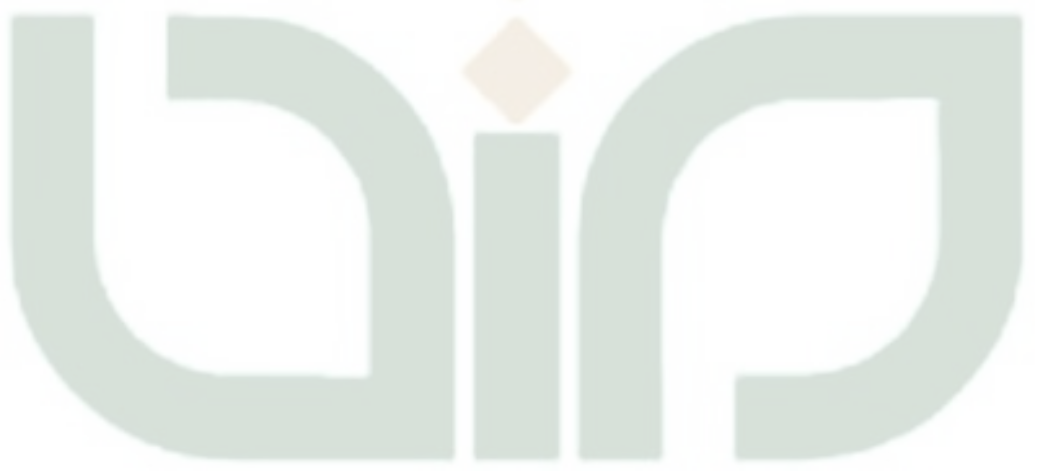




\section{ALAT PENGUMPULAN DATA (APD)}

Item pertanyaan ini yang digunakan untuk memperoleh data mengenai implementasi komunikasi edukatif dalam memadukan iman, ilmu dan amal. Studi pembelajaran PAI di SMA IT Abu Bakar Yogyakarta, jawaban yang anda berikan secara objektif sangat membantu keberhasilan peneliti ini, dan merupakan sumbangsi bagi perkembangan ilmu, dan jawaban yang anda berikan tidak berhubungan dengan nama baik anda atau merugikan anda.

\section{PEDOMAN WAWANCARA \\ (Ditujukan kepada Siswa)/Siswi)}

Pedoman wawancara ini bertujuan mendapatkan informasi tentang implementasi komunikasi edukatif dalam memadukan iman, ilmu dan amal. Studi pembelajaran PAI di SMA IT Abu Bakar Yogyakarta:

\begin{tabular}{l|l|} 
Nama & :Mustofa \\
\hline Jenis Kelamin & $:$ Laki-Laki \\
\hline Umur & $: 17$ Thn \\
Kelas & $: \mathrm{X}^{1}$
\end{tabular}

Status : Siswa SMA IT Abu Bakar Yogyakarta

$\begin{array}{ll}\text { Tanggal } & : 2 \text { Juni } 2018 \\ \text { Waktu } & : 08: 06\end{array}$

1. Pembelajaran PAI yang seperti apa yang anda senangi? Jawab: pembelajaran PAI yang disenangi lebih ke cerita.

2. Ekstra kulikuler apa yang anda ikuti? Jawab: ekstrakulikuler yang saya ikuti rohis dan Bahasa Arab

3. Apakah ada ekstrakulikuler yang mengajarkan tentang iman, ilmu dan amal?

Jawab: ada mentoring dan BPI.

4. Apakah anda sudah menerapkan iman, ilmu dan amal di sekolah ataupun di rumah?

Jawab: sudah shalat lima waktu dan ngaji. 
5. Bagaimana pembelajaran PAI di kelas yang anda dapatkan dari guru PAI?

Jawab: yang saya dapatkan seperti tatacara shalat jenazah

6. Bagaimana komunikasi edukatif anda dengan guru PAI?

Jawab: lancar dan tergantung gurunya

7. Apa saja kegiat yang anda lakukan ketika pembelajaran PAI di kelas?

Jawab: ketika pembelajaran PAI di kelas mendengarkan guru menjelaskan, diskusi dan tanya jawab

8. Apa saja yang di ajarkan Guru PAI?

Jawab: yang di ajarkan tentang rukun iman dan tentang kisah nabi.

9. Apa saja yang anda dapatkan dari pembelajaran PAI?

Jawab: ilmu tentang tata cara ibadah yang baik dan benar

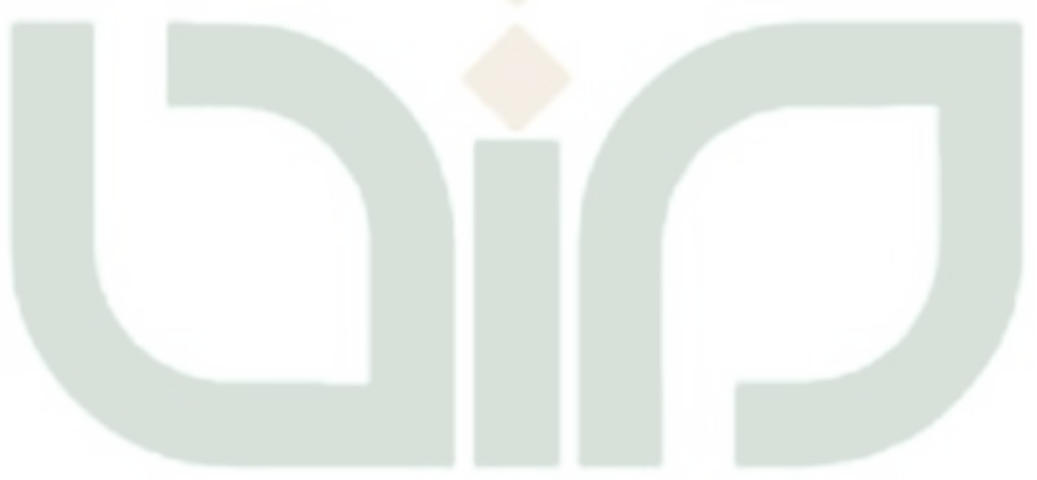




\section{ALAT PENGUMPULAN DATA (APD)}

Item pertanyaan ini yang digunakan untuk memperoleh data mengenai implementasi komunikasi edukatif dalam memadukan iman, ilmu dan amal. Studi pembelajaran PAI di SMA IT Abu Bakar Yogyakarta, jawaban yang anda berikan secara objektif sangat membantu keberhasilan peneliti ini, dan merupakan sumbangsi bagi perkembangan ilmu, dan jawaban yang anda berikan tidak berhubungan dengan nama baik anda atau merugikan anda.

\section{PEDOMAN WAWANCARA}

(Ditujukan kepada Siswa)/Siswi)

Pedoman wawancara ini bertujuan mendapatkan informasi tentang implementasi komunikasi edukatif dalam memadukan iman, ilmu dan amal. Studi pembelajaran PAI di SMA IT Abu Bakar Yogyakarta:

$\begin{array}{ll}\text { Nama } & : \text { Salsa } \\ \text { Jenis Kelamin } & : \text { Perempuan } \\ \text { Umur } & : \text { 17Thn } \\ \text { Kelas } & : \mathrm{X}^{1}\end{array}$

Status : Siswa SMA IT Abu Bakar Yogyakarta

$\begin{array}{ll}\text { Tanggal } & : 2 \text { Juni } 2018 \\ \text { Waktu } & : 08: 11\end{array}$

1. Pembelajaran PAI yang seperti apa yang anda senangi? Jawab: pembelajaran PAI yang di senangi lebih banyak cerita tentang materi akhlak.

2. Ekstra kulikuler apa yang anda ikuti? Jawab: ekstrakulikuler yang saya ikuti pramuka dan mentoring

3. Apakah ada ekstrakulikuler yang mengajarkan tentang iman, ilmu dan amal?

Jawab: ada BPI dan mentoring

4. Apakah anda sudah menerapkan iman, ilmu dan amal di sekolah ataupun di rumah?

Jawab: contohnya shalat lima waktu, menuntut ilmu dan belajar. 
5. Bagaimana pembelajaran PAI di kelas yang anda dapatkan dari guru PAI?

Jawab: yang saya dapatkan seperti materi akhlak, aqidah dan tata cara ibadah yang baik dan benar.

6. Bagaimana komunikasi edukatif anda dengan guru PAI? Jawab: baik dan lancar.

7. Apa saja kegiat yang anda lakukan ketika pembelajaran PAI di kelas? Jawab: ketika pembelajaran PAI di kelas mendengarkan penjelasan guru dan mengerjakan tugas

8. Apa saja yang di ajarkan Guru PAI?

Jawab: yang di ajarkan tentang akhlak dan sikap dalam kehidupan sehari-hari

9. Apa saja yang anda dapatkan dari pembelajaran PAI?

Jawab: yang di dapat tentang sejarah tentang Islam, materi tatacara haji dan wakaf 


\section{ALAT PENGUMPULAN DATA (APD)}

Item pertanyaan ini yang digunakan untuk memperoleh data mengenai implementasi komunikasi edukatif dalam memadukan iman, ilmu dan amal. Studi pembelajaran PAI di SMA IT Abu Bakar Yogyakarta, jawaban yang anda berikan secara objektif sangat membantu keberhasilan peneliti ini, dan merupakan sumbangsi bagi perkembangan ilmu, dan jawaban yang anda berikan tidak berhubungan dengan nama baik anda atau merugikan anda.

\section{PEDOMAN WAWANCARA}

(Ditujukan kepada Siswa)/Siswi)

Pedoman wawancara ini bertujuan mendapatkan informasi tentang implementasi komunikasi edukatif dalam memadukan iman, ilmu dan amal. Studi pembelajaran PAI di SMA IT Abu Bakar Yogyakarta:

\begin{tabular}{l|l} 
Nama & $:$ Zulfikar \\
\hline Jenis Kelamin & $:$ Laki-Laki \\
Umur & $: 17$ Thn \\
Kelas & $: \mathrm{X}^{1}$
\end{tabular}

$\begin{array}{ll}\text { Status } & : \text { Siswa SMA IT Abu Bakar Yogyakarta } \\ \text { Tanggal } & : 2 \text { Juni } 2018 \\ \text { Waktu } & : 09: 22\end{array}$

1. Pembelajaran PAI yang seperti apa yang anda senangi? Jawab: semua senang tergantung mut, pembelajaran PAI yang di senangi temanya adalah perjalanan Rasullah

2. Ekstra kulikuler apa yang anda ikuti? Jawab: ekstrakulikuler yang saya ikuti Bahasa Jepang dan nasid

3. Apakah ada ekstrakulikuler yang mengajarkan tentang iman, ilmu dan amal?

Jawab: ada seperti mentoring dan BPI

4. Apakah anda sudah menerapkan iman, ilmu dan amal di sekolah ataupun di rumah? 
Jawab: sudah contohya shalat tepat waktu dan muroja'ah al-Qur'an.

5. Bagaimana pembelajaran PAI di kelas yang anda dapatkan dari guru PAI?

Jawab: banyak, soalnya gurunya juga enak dan pembelajaran PAI, mempelajarai ilmu-ilmu yang baru yang bisa di pelajari

6. Bagaimana komunikasi edukatif anda dengan guru PAI?

Jawab: alhamdulilah baik dan lancar dan gurunya sering cerita.

7. Apa saja kegiat yang anda lakukan ketika pembelajaran PAI di kelas?

Jawab: ketika pembelajaran PAI di kelas mencatat, mendengarkan guru menjelaskan materi dan mengerjakan tugas di buku LKS

8. Apa saja yang di ajarkan Guru PAI?

Jawab: yang di ajarkan seperti pembelajaran tentang rukun iman.

9. Apa saja yang anda dapatkan dari pembelajaran PAI?

Jawab: bayak, guru yang mengajarkan ramah kalau dalam menjelaskan mudah di pahami dan bisa di terapkan dalam kehidupan sehari-hari.

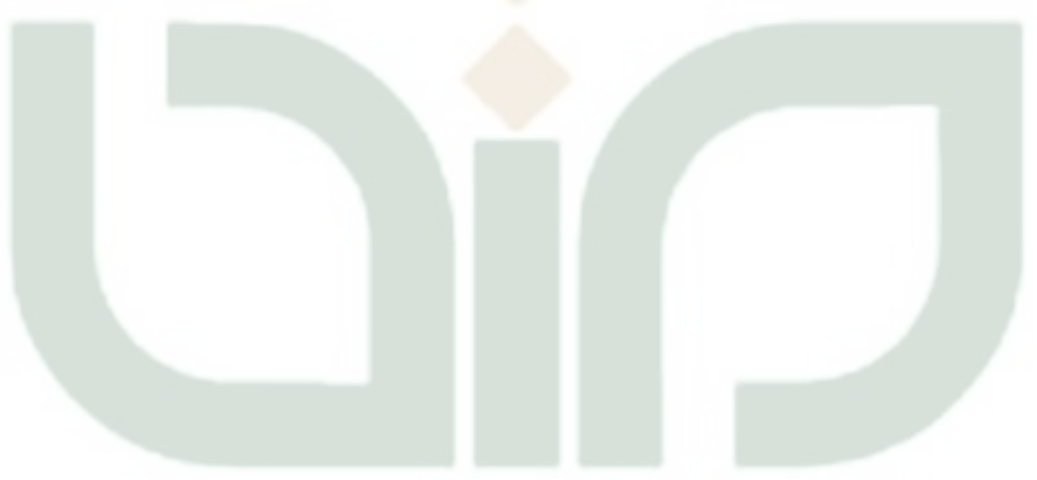




\section{CURRICULUM VITAE}

\section{A. Identitas diri:}

1. Nama

2. NIM

3. Tanggal Lahir

4. Tempat Lahir

5. Jenis Kelamin

6. Agama

7. Alamat

8. Email

9. Nama Orang Tua:
a. Bapak
Pekerjaan
b. Ibu
Pekerjaan

: Andrianto

: 17204010045

: 23 Desember 1995

: OKU TIMUR

: Laki-laki

: Islam

: Desa Gantiwarno

Rt: 02,Rw: 03, Kec. Blitang III,

Kab. OKU TIMUR, Provinsi. Sumatra Selatan

: andriantoanto949@gmail.com

\section{B. Riwayat Pendidikan Formal}

1. SDN 1 Gantiwarno, 2001-2007

2. MTS Darul Ulum Karangsari 2007-2010

3. MAN Gumawang 2010-2013

4. UIN Raden Fatah Palembang2013-2017

5. UIN Sunan Kalijaga Yogyakarta 2017 sampai sekarang

C. Pendidikan Informal:

1. Pelatihan Yuk Wakaf di Hotel Amaris Palembang

2. Pelatihan Karya Ilmiah dan Jurnal dibidang Sains Teknologi dan Pendidikan

3. Pelatihan Jurnal di Indonesia Research Corner

\section{Prestasi/Penghargaan}

1. Peserta kegiatan IMAKIPSI SE-INDONESIA (2014)

2. Lulusan S1 (Sarjana) dengan PredikatSangat Baik $(3,58)$ Masa Studi 3,5 Tahun (2017).

3. Juara Harapan 3 Lomba Puisi di UNSRI Palembang 2018 


\section{E. Pengalaman Organisasi}

1. Pengurus HMJ PAI UIN Raden Fatah Palembang.

2. Pengurus Dewan Eksekutif Mahasiwa Fakultas Ilmu Tarbiyah dan Keguruan (DEMAF FITK) UIN Raden Fatah Palembang.

3. Pengurus Dewan Eksekutif mahasiswa UIN Raden Fatah Palembang (DEMAU)

4. Pengurus Ikatan Mahasiswa Blitang (IKMB)

5. Pengurus Lembaga Tilawatil Qur'an dan Dakwah (LPTQ \& D)

6. Pengurus Koperasi Mahasiswa (KOPMA)

7. Pengurus Kesatuan Aksi Mahasiswa Muslim Indonesia (KAMMI)

8. Pengurus Lembaga Penelitian dan Pengembangan (Litbang)

9. Pengurus Ta'mir Masjid Al-Huda di Lebak Mulyo

10. Pengurus Ikatan Remaja Masjid Agung Palembang (IRMA)

11. Anggota Forum Komunikasi Mahasiswa Program Magister Fakultas Ilmu Tarbiyah dan Keguruan (FKMPM FITK) Di Yogyakarta.

\section{F. Pengalaman Kerja}

1. Guru TK/TPA Masjid Nurul Hijrah (2013-2017)

2. Guru Prifat Agama Islam (2014-2017)

3. Guru TK/TPA Masjid Safinaturrahmah Sapen (2018 sampai sekarang)

4. Takmir Masjid Al-Huda (2013-2018)

5. Admin Lapangan Royal Pet-Shop (2017 sampai sekarang)

\section{G. Karya Ilmiah}

1. Artikel

\begin{tabular}{|l|l|l|}
\hline No & Judul & Publikasi \\
\hline 1 & FAKTOR-FAKTOR PENYEBAB & Jurnal PAI Raden \\
& KENAKALAN REMAJA DI LEBAK & Fatah, Vol. 1, No. \\
& MULYO KECAMATAN KEMUNING & (Januari, 2019): \\
& KOTA PALEMBANG & $82-104$. \\
\hline 2 & $\begin{array}{l}\text { The Philosophy Of Iqra' On Islamic } \\
\text { Education }\end{array}$ & $\begin{array}{l}\text { Hunafar Jurnal } \\
\text { Studia Islamika, } \\
\end{array}$ \\
& & $\begin{array}{l}\text { Vol.15, No.1, } \\
\text { (Desember, 2018): } \\
\end{array}$ \\
\hline
\end{tabular}

2. Penelitiaan

\begin{tabular}{|l|l|lr|}
\hline 1 & Faktor-faktor Penyebab Kenakalan & Islamic & State \\
& $\begin{array}{l}\text { Remaja di Lebak Mulyo Kecamatan } \\
\text { Kemuning Kota Palembang }\end{array}$ & $\begin{array}{l}\text { University } \\
\text { Palembang, 2017 }\end{array}$ \\
\hline
\end{tabular}


3. Buku

\begin{tabular}{|c|c|c|}
\hline $\begin{array}{l}\text { Teori Pembelajaran Sebuah } \\
\text { Pendekatan Baru dalam Pendidikan } \\
\text { Islam }\end{array}$ & $\begin{array}{lrr}\text { Cetakan } & \text { ke-1 } \\
\text { Agustus } & 2018 \text { CV } \\
\text { ISTANA } & \text { AGENCY }\end{array}$ & Anggota \\
\hline
\end{tabular}

\section{H. Pelatihan Profesional}

\begin{tabular}{|c|c|c|c|}
\hline Tahun & Jenis Pelatihan/ Seminar & Penyelenggara & Jangka Waktu \\
\hline 2017 & User Education & $\begin{array}{ll}\text { Perpustakaan } & \text { UIN } \\
\text { Sunan Kalijaga } & \\
\end{array}$ & September 2017 \\
\hline 2017 & $\begin{array}{l}\text { Seminar Nasional Demokrasi } \\
\text { Hak Asasi Manusia dan Hak- } \\
\text { Hak Kewarganegaraan }\end{array}$ & $\begin{array}{l}\text { Mahkamah } \\
\text { Konstitusi Republik } \\
\text { Indonesia }\end{array}$ & 1 Agustus 2017 \\
\hline 2017 & $\begin{array}{lcr}\text { Seminar } & \text { Nasional dan } \\
\text { Launcing } & \text { Pusat } & \text { Studi } \\
\text { Pancasila dan Bela Negara }\end{array}$ & UIN Sunan Kalijaga & 9 Agustus 2017 \\
\hline 2017 & $\begin{array}{l}\text { Roadshow Seminar Asuransi } \\
\text { Syariah-Batch V }\end{array}$ & $\begin{array}{l}\text { Masyarakat } \\
\text { Ekonomi Syariah } \\
\text { Wilayah Yogyakarta }\end{array}$ & 16 Agustus 2017 \\
\hline 2017 & $\begin{array}{l}\text { Launching Website Cak Nur } \\
\text { \& Seminar Pendidikan Islam } \\
\text { Indonesia }\end{array}$ & $\begin{array}{l}\text { FITK UIN Sunan } \\
\text { Kalijaga }\end{array}$ & 11 Desember 2017 \\
\hline 2017 & $\begin{array}{l}\text { Launcing Gerakan Nasional } \\
\text { "KAMI Indonesia" }\end{array}$ & KAMI INDONESIA & 16 Desember 2017 \\
\hline 2018 & $\begin{array}{lcr}\begin{array}{l}\text { Seminar } \\
\text { rangka }\end{array} & \text { Nasional "dalam } \\
\text { nusantara } & \text { (SERSANTARA) } \\
\text { ke } 10 & & \text { santri } \\
\end{array}$ & $\begin{array}{ll}\text { CSSMORA } & \text { UIN } \\
\text { Sunan Kalijaga } & \end{array}$ & 1 Maret 2018 \\
\hline 2018 & $\begin{array}{l}\text { Peluncuran dan Bedah Buku } \\
\text { "Menulis itu Mudah" }\end{array}$ & $\begin{array}{lr}\text { Bitread } & \text { Publishing } \\
\text { dan } & \text { Gerakan } \\
\text { Menulis } & \text { Populer } \\
\end{array}$ & 7 Maret 2018 \\
\hline 2018 & $\begin{array}{l}\text { Paradigma Pembelajaran di } \\
\text { Perguruan Tinggi }\end{array}$ & $\begin{array}{l}\text { FITK UIN Sunan } \\
\text { Kalijaga }\end{array}$ & 8 Maret 2018 \\
\hline 2018 & $\begin{array}{l}\text { Pelatihan "Pembangunan } \\
\text { Softskill dalam Pendidikan" }\end{array}$ & $\begin{array}{l}\text { FITK UIN Sunan } \\
\text { Kalijaga }\end{array}$ & 15 Maret 2018 \\
\hline 2018 & $\begin{array}{l}\text { Indonesia Journal } \quad \text { Of } \\
\text { Interdisciplinary } \\
\text { Studies (IJIIS) }\end{array}$ & $\begin{array}{l}\text { Postgraduate } \\
\text { Pogram, Faculty Of } \\
\text { Islamic Studies, } \\
\text { Islamic University } \\
\text { Of Indonesia }\end{array}$ & 24 Maret 2018 \\
\hline
\end{tabular}




\begin{tabular}{|c|c|c|c|}
\hline 2018 & $\begin{array}{l}\text { Peluncuran Buku dan } \\
\text { Seminar Nasional "Realitas } \\
\text { dan Tantangan } \\
\text { Konstitusionalisme HAM di } \\
\text { Tahun Politik }\end{array}$ & $\begin{array}{l}\text { Fakultas Hukum UII } \\
\text { Yogyakarta }\end{array}$ & 31 Maret 2018 \\
\hline 2018 & $\begin{array}{l}\text { Seminar } \quad \text { Kebangsaan } \\
\text { "Mengurai Benang Kusut } \\
\text { Intoleran \& Terorisme" }\end{array}$ & $\begin{array}{l}\text { DEMA UIN Sunan } \\
\text { Kalijaga }\end{array}$ & 22 Maret 2018 \\
\hline 2018 & $\begin{array}{lr}\text { Seminar } & \text { Nasional } \\
\text { "Harmonisasi } & \text { Umat } \\
\text { Beragama di Tahun Politik" }\end{array}$ & $\begin{array}{ll}\text { DEMA-FDK } & \text { UIN } \\
\text { Sunan Kalijaga } & \end{array}$ & 11 April 2018 \\
\hline 2018 & $\begin{array}{l}\text { Seminar } \quad \text { Nasional Anti } \\
\text { Narkoba "Millenial, Bebas } \\
\text { Berkarya Tanpa Narkoba" }\end{array}$ & $\begin{array}{lr}\text { DEMA } & \text { Fakultas } \\
\text { Ilmu Sosial dan } \\
\text { Humaniora } & \text { UIN } \\
\text { Sunan Kalijaga } & \end{array}$ & 13 April 2018 \\
\hline 2018 & $\begin{array}{llr}\text { Seminar } & \text { Nasional } & \text { dan } \\
\text { Launching } & \text { Program } & \text { Studi } \\
\text { Doktor (S3) } & \text { PAI FITK UIN } \\
\text { Sunan Kalijaga }\end{array}$ & $\begin{array}{l}\text { FITK UIN Sunan } \\
\text { Kalijaga }\end{array}$ & 19 April 2018 \\
\hline 2018 & $\begin{array}{l}\text { Seminar Integrasi "Yang } \\
\text { Muda Melawan Korupsi"" }\end{array}$ & $\begin{array}{l}\text { GPMK berkerjasama } \\
\text { dengan } \quad \text { DEMA } \\
\text { FISHUM UIN } \\
\text { SunanKalijaga }\end{array}$ & 2 Mei 2018 \\
\hline 2018 & $\begin{array}{l}\text { Talkshow Literasi \& Dialog } \\
\text { Pendidikan Nasional }\end{array}$ & $\begin{array}{l}\text { DEMA FITK UIN } \\
\text { Sunan Kalijaga }\end{array}$ & 15 Mei 2018 \\
\hline 2018 & $\begin{array}{l}\text { Seminar Politik Generasi } \\
\text { Millenial di Pemilu } 2019\end{array}$ & $\begin{array}{l}\text { DEMA UIN Sunan } \\
\text { Kalijaga }\end{array}$ & 19September 2018 \\
\hline 2018 & $\begin{array}{l}\text { International Conference RE- } \\
\text { MAKING INDONESIA }\end{array}$ & $\begin{array}{l}\text { Center For Religion } \\
\text { and Science, State } \\
\text { Islmaic University } \\
\text { Sunan Kalijaga }\end{array}$ & 12 Oktober 2018 \\
\hline 2018 & 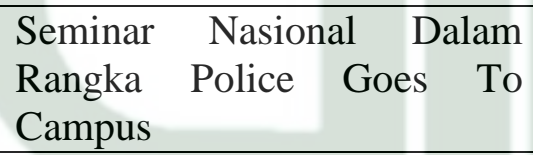 & $\begin{array}{l}\text { Kepala KORPS Lalu } \\
\text { Lintas POLRI }\end{array}$ & 25 Oktober 2018 \\
\hline 2018 & $\begin{array}{lr}\begin{array}{l}\text { Seminar Moderasi } \\
\text { "Memaknai }\end{array} & \text { dan } \\
\text { Membumikan Konsep } & \text { Ulil } \\
\text { Albab Di Indonesia } & \\
\end{array}$ & $\begin{array}{lr}\text { Direktorat } & \\
\text { Pendidikan } & \& \\
\text { Pembinaan } & \text { Agama } \\
\text { Islam } & \\
\end{array}$ & 30 Oktober 2018 \\
\hline 2018 & $\begin{array}{lr}\text { Launching } & \text { Majalah } \\
\text { SINERGIA Volume XXII } \\
\text { dan Dialog Publik Refleksi } 90 \\
\text { Tahun Sumpah Pemuda } \\
\text { dengan tema "Teladan Jasa } \\
\text { Cut Nyak Dien-RA Kartini } \\
\text { Pasca Kesaksian Hoaks } \\
\text { Hanum Rais" }\end{array}$ & $\begin{array}{lr}\text { Lembaga } & \text { Pers } \\
\text { Mahasiswa } & \text { Islam } \\
\text { (LAPMI) } & \text { SINERGI } \\
\text { HMI } & \text { Cabang } \\
\text { Yogyakarta } & \\
\text { bekerjasama } & \text { dengan } \\
\text { Himpunan } & \text { Aktivis } \\
\text { Milenial } & \text { (HAM) } \\
\end{array}$ & 31 Oktober 2018 \\
\hline
\end{tabular}




\begin{tabular}{|c|c|c|c|}
\hline & & $\begin{array}{l}\text { Indonesia dan LPM } \\
\text { Advokasi Fakultas } \\
\text { Syariah UIN Sunan } \\
\text { Kalijaga }\end{array}$ & \\
\hline 2018 & $\begin{array}{l}\text { Seminar Nasional Pemuda } \\
\text { dan Bela Negara dalam } \\
\text { Rangka Pekan Pancasila dan } \\
\text { Bela Negara }\end{array}$ & $\begin{array}{lr}\text { Pusat } & \text { Studi } \\
\text { Pancasila dan Bela } \\
\text { Negara UIN Sunan } \\
\text { Kalijaga }\end{array}$ & 1-3November 2018 \\
\hline 2018 & $\begin{array}{l}\text { Seminar Nasional dengan } \\
\text { Tema Urgensi Kesadaran } \\
\text { Literasi Digital Dalam Dunia } \\
\text { Pendidikan }\end{array}$ & $\begin{array}{l}\text { SEMA FITK UIN } \\
\text { Sunan Kalijaga }\end{array}$ & 23 November 2018 \\
\hline 2018 & $\begin{array}{l}\text { Seminar Nasional Pendidikan } \\
\text { Multikultural Nusantara }\end{array}$ & $\begin{array}{l}\text { FITK UIN Sunan } \\
\text { Kalijaga Yogyakarta } \\
\text { bekerjasama dengan } \\
\text { Rumah Kearifan }\end{array}$ & 6 Desember 2018 \\
\hline 2018 & $\begin{array}{l}\text { Seminar } \quad \text { Nasional dan } \\
\text { Pesantren Anti Korupsi }\end{array}$ & $\begin{array}{l}\text { GPMK } \\
\text { Berkerjasama } \\
\text { Dengan DEMA } \\
\text { FISHUM DIN } \\
\text { Sunan Kalijaga }\end{array}$ & 10 Desember 2018 \\
\hline 2018 & $\begin{array}{l}\text { Sosialisasi Empat Pilar MPR } \\
\text { RI }\end{array}$ & $\begin{array}{l}\text { MPR RI } \\
\text { berkerjasama dengan } \\
\text { UIN Sunan Kalijaga }\end{array}$ & 2018 \\
\hline 2018 & $\begin{array}{l}\text { Seminar } \\
\text { Ketenagakerjaan "Revolusi } \\
\text { Industri 4.0 : Tantangan dan } \\
\text { Peluang" }\end{array}$ & $\begin{array}{l}\text { DEMA FEBI UIN } \\
\text { Sunan Kalijaga }\end{array}$ & 2018 \\
\hline 2018 & $\begin{array}{l}\text { Pelaksanaan Kurikulum } \\
\text { Muata Lokal Pada MAN 1, } \\
\text { MAN 2, dan SMA Negeri } 7 \\
\text { Plus Kota Bengkulu }\end{array}$ & Promosi Doktor & 2018 \\
\hline 2018 & Etika Politik M. Natsir & Promosi Doktor & 2018 \\
\hline 2018 & $\begin{array}{l}\text { Islamisme, Kapitalisme } \\
\text { Ruang Kota, dan Gerakan } \\
\text { Politik Masyarakat Urban: } \\
\text { Aliansi Ekonomi-Politik PKS, } \\
\text { Kristen, dan Tionghoa di } \\
\text { Salatiga }\end{array}$ & Promosi Doktor & 2018 \\
\hline 2018 & $\begin{array}{l}\text { Model Pengembangan } \\
\text { Organizational Citizenzhip } \\
\text { Behavior (OCB) Karyawan } \\
\text { Berbasis Nilai Islam }\end{array}$ & Promosi Doktor & 2018 \\
\hline
\end{tabular}




\begin{tabular}{|l|l|l|l|}
\hline 2019 & Menjadi Intelektual Organik & $\begin{array}{l}\text { Rumah Kearifan } \\
\text { Lokal berkerjasama } \\
\text { dengan FKMPM dan } \\
\text { KMP }\end{array}$ & Januari 2019 \\
\hline
\end{tabular}

Yogyakarta, Januari 2019

Penulis,

\author{
Andrianto \\ NIM. 17204010045
}

